SHAW CREEK AND SHAWNEE PEAK AIRBORNE MAGNETIC AND RADIOMETRIC GEOPHYSICAL SURVEY

Emond, A.M., and MPX Geophysics LTD

Geophysical Report 2020-16

2020

STATE OF ALASKA

DEPARTMENT OF NATURAL RESOURCES

DIVISION OF GEOLOGICAL \& GEOPHYSICAL SURVEYS
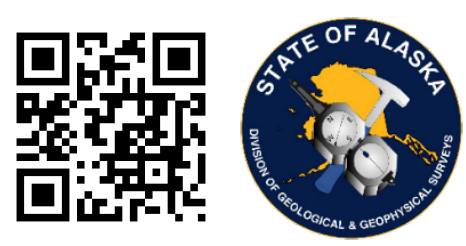
STATE OF ALASKA

Mike Dunleavy, Governor

\section{DEPARTMENT OF NATURAL RESOURCES}

Corri A. Feige, Commissioner

\section{DIVISION OF GEOLOGICAL \& GEOPHYSICAL SURVEYS}

Steve Masterman, State Geologist \& Director

Publications produced by the Division of Geological \& Geophysical Surveys are available to download from the DGGS website (dggs.alaska.gov). Publications on hard-copy or digital media can be examined or purchased in the Fairbanks office:

\section{Alaska Division of Geological \& Geophysical Surveys (DGGS)}

3354 College Road | Fairbanks, Alaska 99709-3707

Phone: 907.451.5010 | Fax 907.451.5050

dggspubs@alaska.gov $\mid$ dggs.alaska.gov

\section{DGGS publications are also available at:}

Alaska State Library, Historical

Collections \& Talking Book Center

395 Whittier Street

Juneau, Alaska 99801

Alaska Resource Library and

Information Services (ARLIS)

3150 C Street, Suite 100

Anchorage, Alaska 99503

\section{Suggested citation:}

Emond, A.M., and MPX Geophysics LTD, 2020, Shaw Creek and Shawnee Peak airborne magnetic and radiometric geophysical survey: Alaska Division of Geological \&

Geophysical Surveys Geophysical Report 2020-16, 4 p. https://doi.org/10.14509/30551
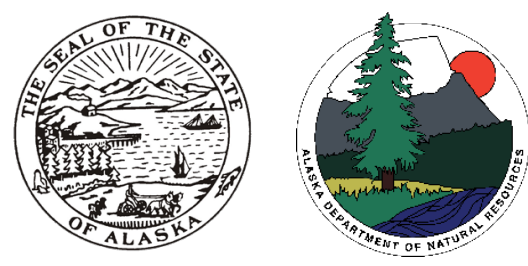


\section{SHAW CREEK AND SHAWNEE PEAK AIRBORNE MAGNETIC AND RADIOMETRIC GEOPHYSICAL SURVEY \\ Emond, A.M., ${ }^{1}$ and MPX Geophysics LTD ${ }^{2}$}

\section{ABSTRACT}

The Shaw Creek and Shawnee Peak airborne magnetic and radiometric geophysical survey covers parts of the Big Delta and Eagle quadrangles northeast of Delta Junction, Alaska (fig. 1). Magnetic and radiometric data were collected with a helicopter July 4-25, 2020 by MPX Geophysics LTD. A total of 10,100 line kilometers were collected over approximately 2,600 square kilometers. The magnetometer was mounted to a forward-facing fixed boom ("stinger"). The radiometric crystals were located in the cabin of the helicopter.

Data were collected in eight named blocks. Mertie Mountains, Shaw Creek, and Volkmar River have a line spacing of 400 meters $(\mathrm{m})$ and a mean ground clearance of $130 \mathrm{~m}$. Stoneboy has a line spacing of $200 \mathrm{~m}$ and a mean ground clearance of $80 \mathrm{~m}$. Eagle, Echo, Healy, and LMS-X have a line spacing of $100 \mathrm{~m}$ and a mean ground clearance of $80 \mathrm{~m}$.

\section{PURPOSE}

The data from the Shaw Creek and Shawnee Peak airborne magnetic and radiometric geophysical survey will be used for guiding geologic mapping, promoting resource exploration, generating mineral exploration targets, and be a part of the continuous regional magnetic data coverage of the Yukon Tanana Uplands.

Portions of these blocks were collected over existing airborne geophysical data. These portions were collected to improve the magnetic data quality and resolution in these areas to support mineral exploration and targeting.

\section{SURVEY OVERVIEW DESCRIPTION}

This document provides an overview of the survey and includes text and figures of select primary and derivative products of this survey. A table of digital data packages available for download is provided to assist users in data selection. For reference, a catalog of the available maps is presented in reduced resolution. Please consult the metadata, project report, and digital data packages for more information and data.

\section{ACKNOWLEDGMENTS}

ThisworkwassupportedbyStateofAlaska and by industry partners Northern Star (Pogo) LLC, Millrock Resources Inc., and Northway Resources Corp.

\footnotetext{
${ }^{1}$ Alaska Division of Geological \& Geophysical Surveys, 3354 College Road, Fairbanks, Alaska 99709-3707

${ }^{2}$ 4-355 Harry Walker Parkway North, Newmarket, Ontario, L3Y7B3, Canada
} 


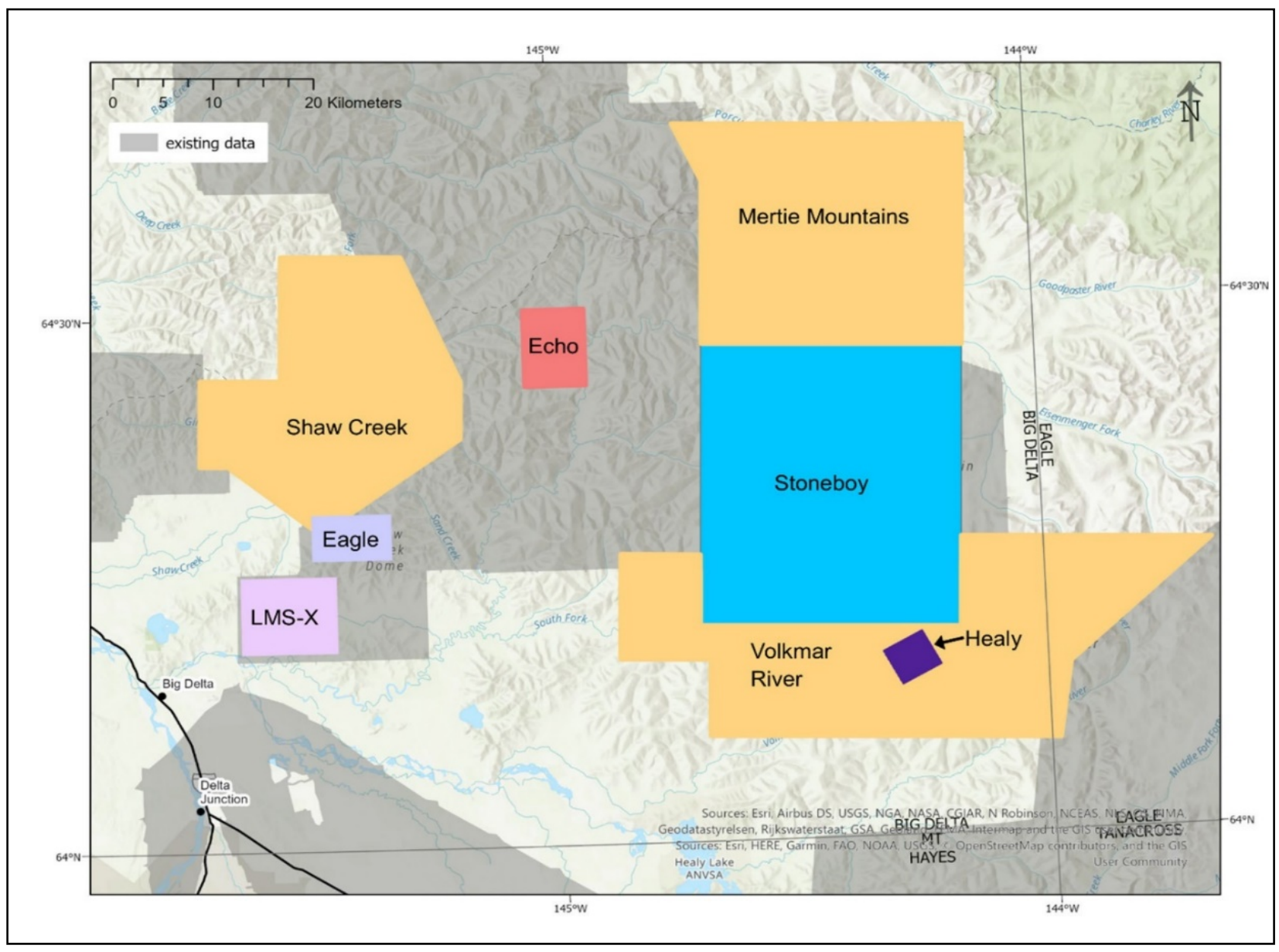

Figure 1. Named geophysical survey blocks location map with major roads, towns, and 1:250,000-scale USGS quadrangle boundaries. Prior DGGS surveys shown in gray.

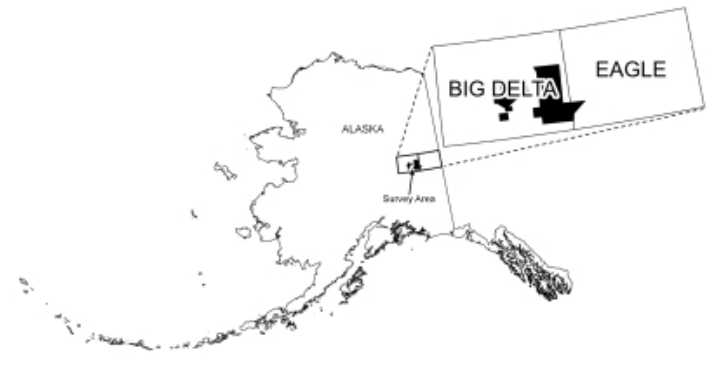




\section{AVAILABLE DATA}

\begin{tabular}{|c|c|c|}
\hline Data Type & Provider & Description \\
\hline ascii_data & contractor & ASCII format line data, other ASCII data \\
\hline databases_geosoft & contractor & $\begin{array}{l}\text { Geosoft format database of final line data, other Geosoft format } \\
\text { databases }\end{array}$ \\
\hline documents & contractor & Project report \\
\hline grids_ermapper & contractor & Geographically registered gridded data, ER Mapper ERS format \\
\hline grids_geosoft & contractor & Geosoft-format gridded data \\
\hline images_registered & contractor & RGB GeoTiff format images of gridded data \\
\hline $\mathrm{kmz}$ & contractor & $\begin{array}{l}\text { keyhole markup language }(\mathrm{kml}) \mathrm{kmz} \text { archive files of project data. } \\
\text { Viewable in Google Earth and other compatible programs }\end{array}$ \\
\hline maps_pdf_format & contractor & $\begin{array}{l}\text { Printable and geographically registered maps in pdf format. } \\
\text { Compatible with mobile device navigation and desktop mapping } \\
\text { applications }\end{array}$ \\
\hline $\begin{array}{l}\text { maps_geosoft_ } \\
\text { format }\end{array}$ & contractor & maps as Geosoft packed map files \\
\hline maps_jpg_format & contractor & Printable maps jpg format \\
\hline photos_flightpath & contractor & $\begin{array}{l}\text { Survey flight path downward facing photos with GPS location in } \\
\text { exif data }\end{array}$ \\
\hline vector_data & contractor & Line path and survey boundary in ESRI shapefile (SHP) format \\
\hline
\end{tabular}




\section{PROCESS STEPS}

\begin{tabular}{|c|c|c|}
\hline DATE & STEP & DETAIL \\
\hline 2020 & $\begin{array}{l}\text { Data collection, } \\
\text { processing, and } \\
\text { delivery }\end{array}$ & $\begin{array}{l}\text { The airborne geophysical data were acquired under contract with MPX } \\
\text { Geophysics Ltd. Airborne geophysical data for the areas were acquired and } \\
\text { processed by MPX Geophysics Ltd. The contractor's project report and other } \\
\text { supporting documents are in the "documents" digital data package. They } \\
\text { provide detailed documentation of the system specifications, data collection, } \\
\text { processing, and delivery. }\end{array}$ \\
\hline 2020 & Preliminary Data & $\begin{array}{l}\text { DGGS published preliminary data } 12 \text { days after the completion of data } \\
\text { collection }\end{array}$ \\
\hline 2020 & $\begin{array}{l}\text { Data Cataloged for } \\
\text { Archival and } \\
\text { Publication }\end{array}$ & $\begin{array}{l}\text { All files were renamed and placed in a standardized set of folders according to } \\
\text { the DGGS Geophysics Data Management Manual. DGGS generated } \\
\text { additional supporting documentation, which includes readme text files, } \\
\text { maps, figures, survey overview report, and FGDC compliant metadata. } \\
\text { Preliminary data were removed from the DGGS website and replaced with } \\
\text { reorganized data and more comprehensive documentation. }\end{array}$ \\
\hline
\end{tabular}

\section{MAPS}

Maps in PDF (georeferenced), JPG, and Geosoft format were created by the contractor. The eleven map types available for each of the eight survey blocks are listed below and shown on the following pages.

\section{Location Map}

- Flownflight path overUSGStopographic mapasbackgroundlayer

\section{Magneticdata}

- Residual Magnetic Intensityin nT

- Calculated analytic signal of the residual magnetic field in nT/m

- Computed 1stvertical derivative of the residual magnetic field in nT/m

\section{Radiometric data}

- Total Air Absorbed Dose Rate in nGy/h

- Equivalent concentration of Potassium $(\mathrm{K})$ as percentK

- Equivalent concentration of Thorium(Th) in ppm

- Equivalent concentration of Uranium(U) in ppm

- Uranium ThoriumRatio

- Potassium ThoriumRatio

- Ternary Grid:percent K - equivalent U - equivalent Th 


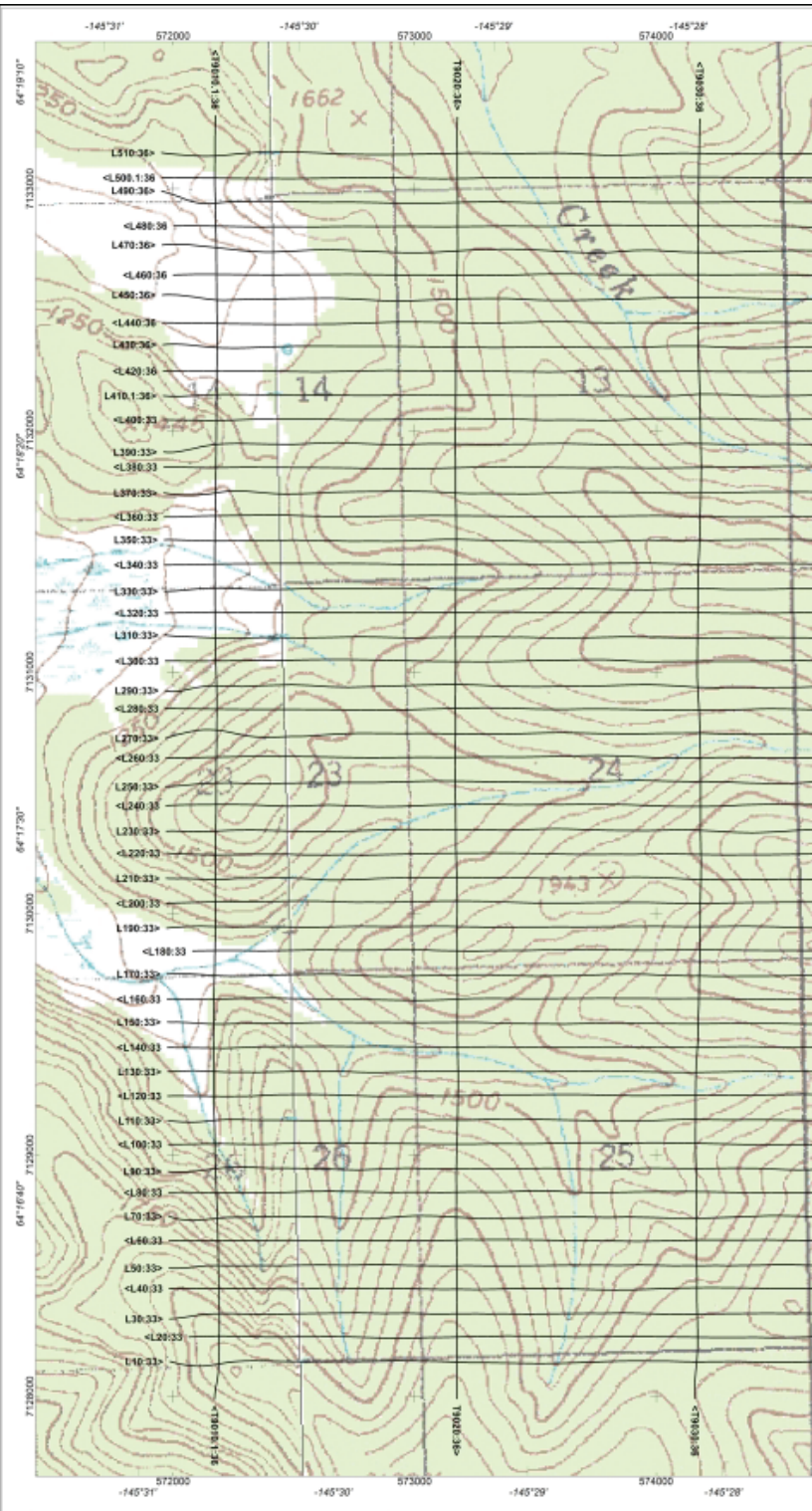

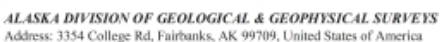

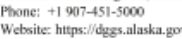

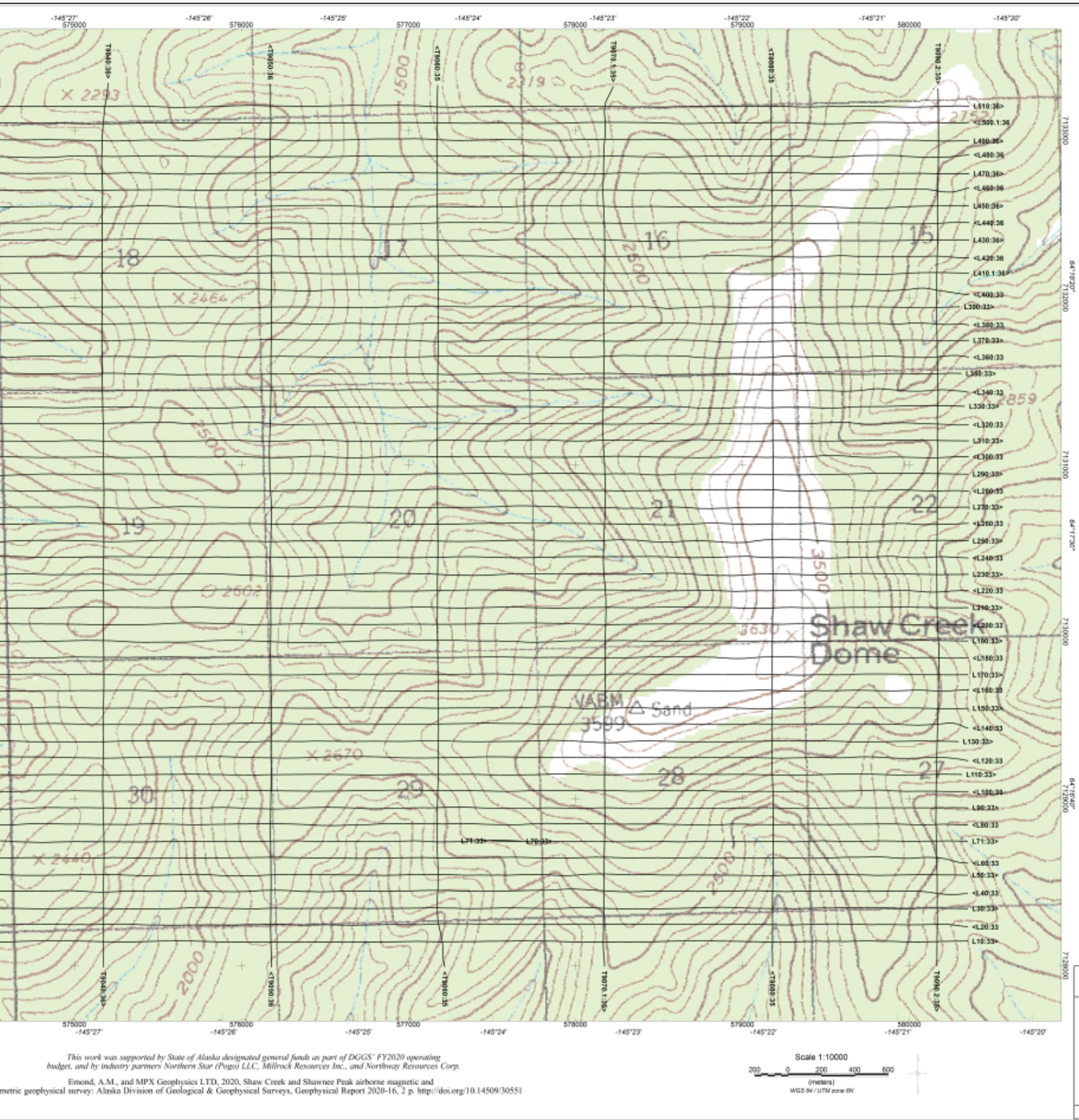

$8)_{M P X}$ semes mann

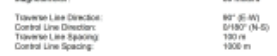
s.t. $\sum-m$ sins = $-\sin 2 \cos 10$ sis

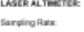

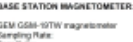

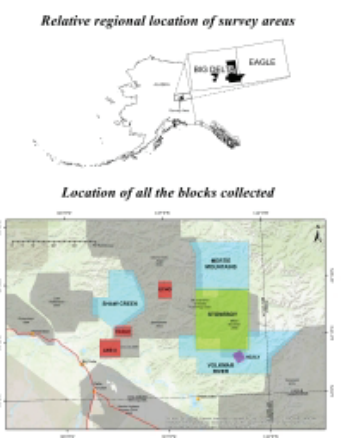

Alaska Division of Geological \&
Geophysical Survegs

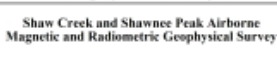
Flown Flight Path over USGS Topo Map Eagle Block Gophusicel Report 20 


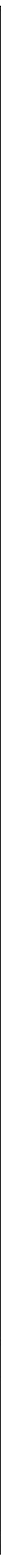




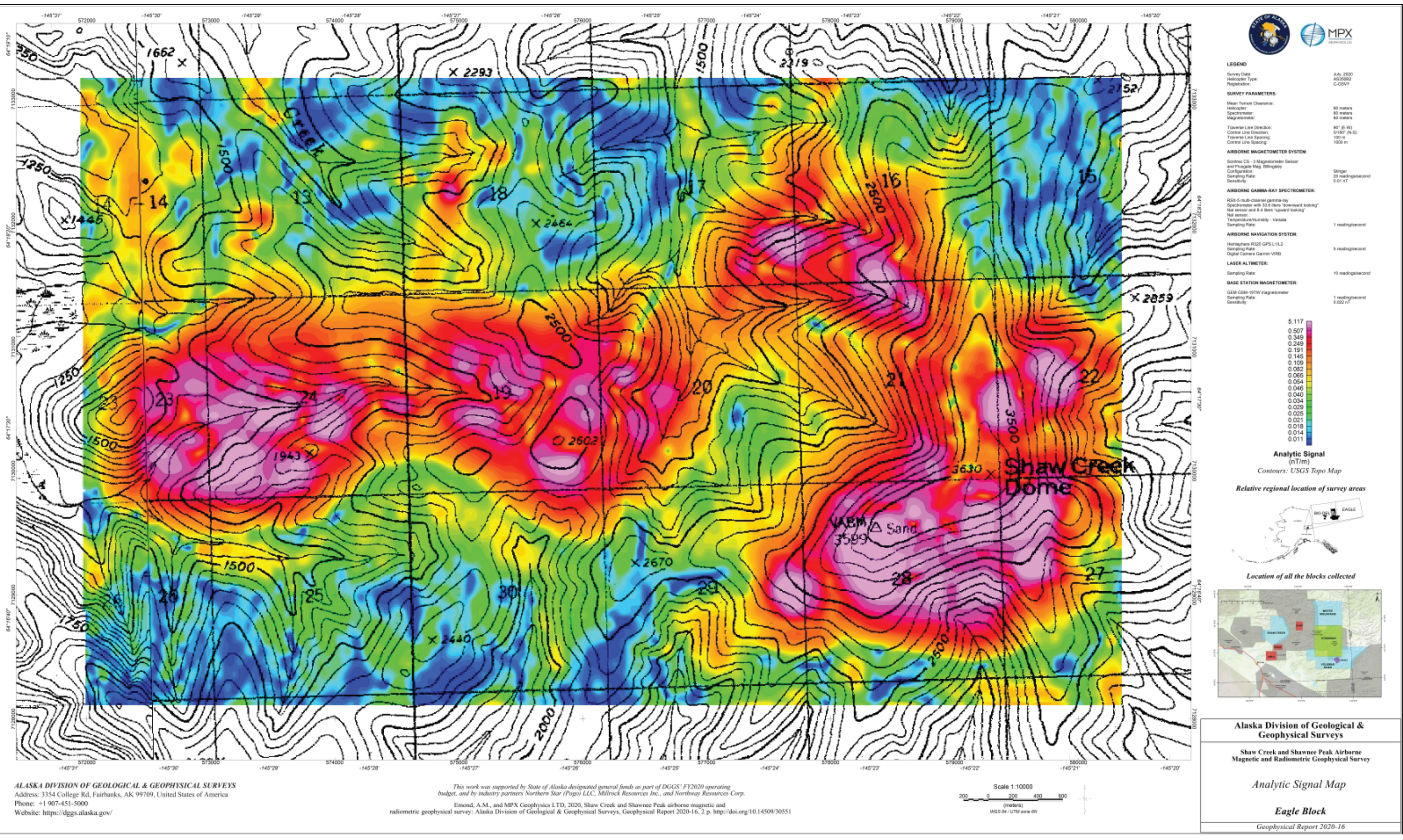




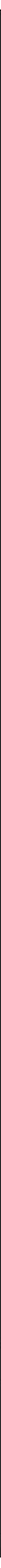




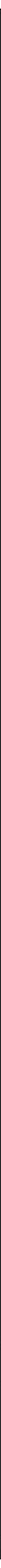




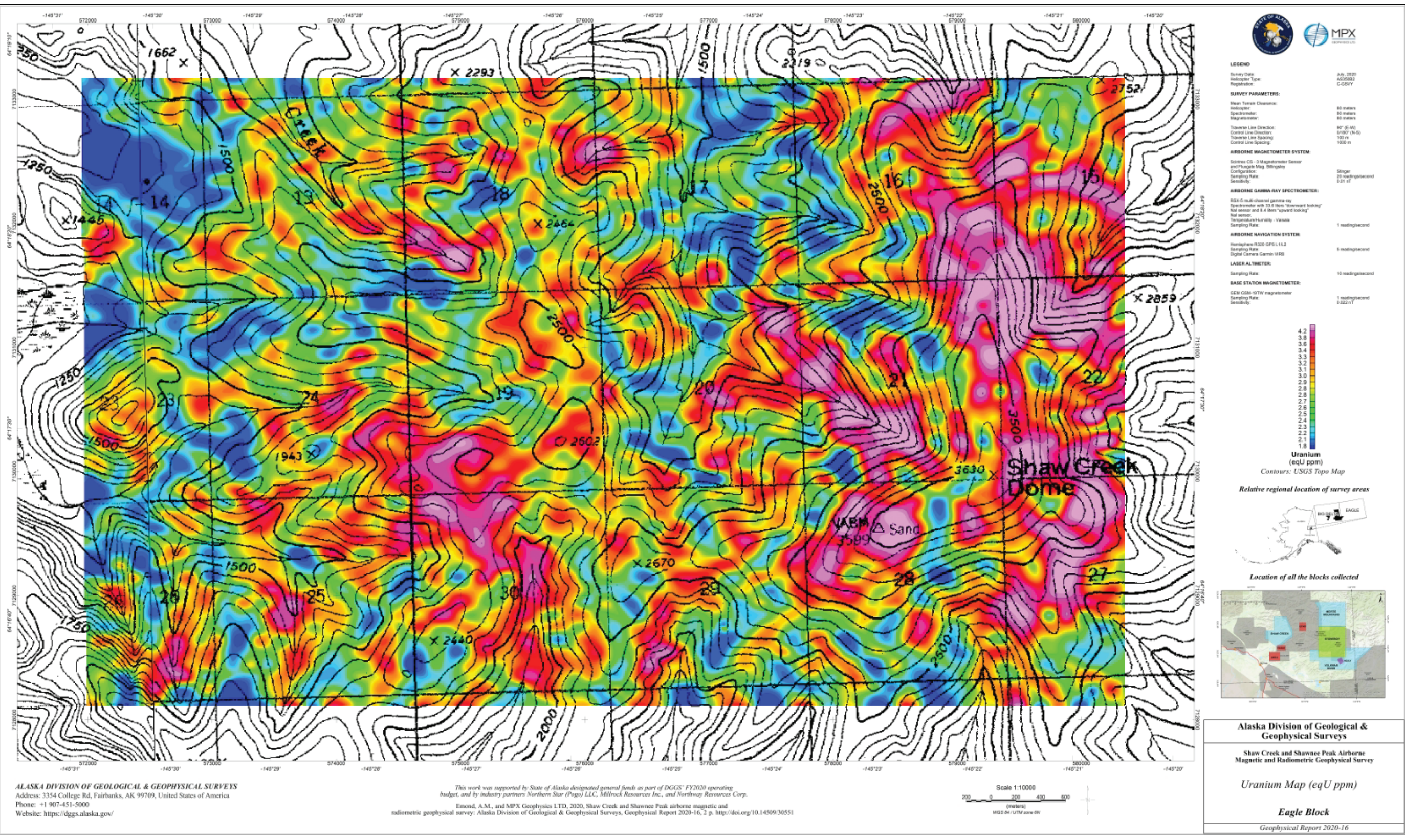




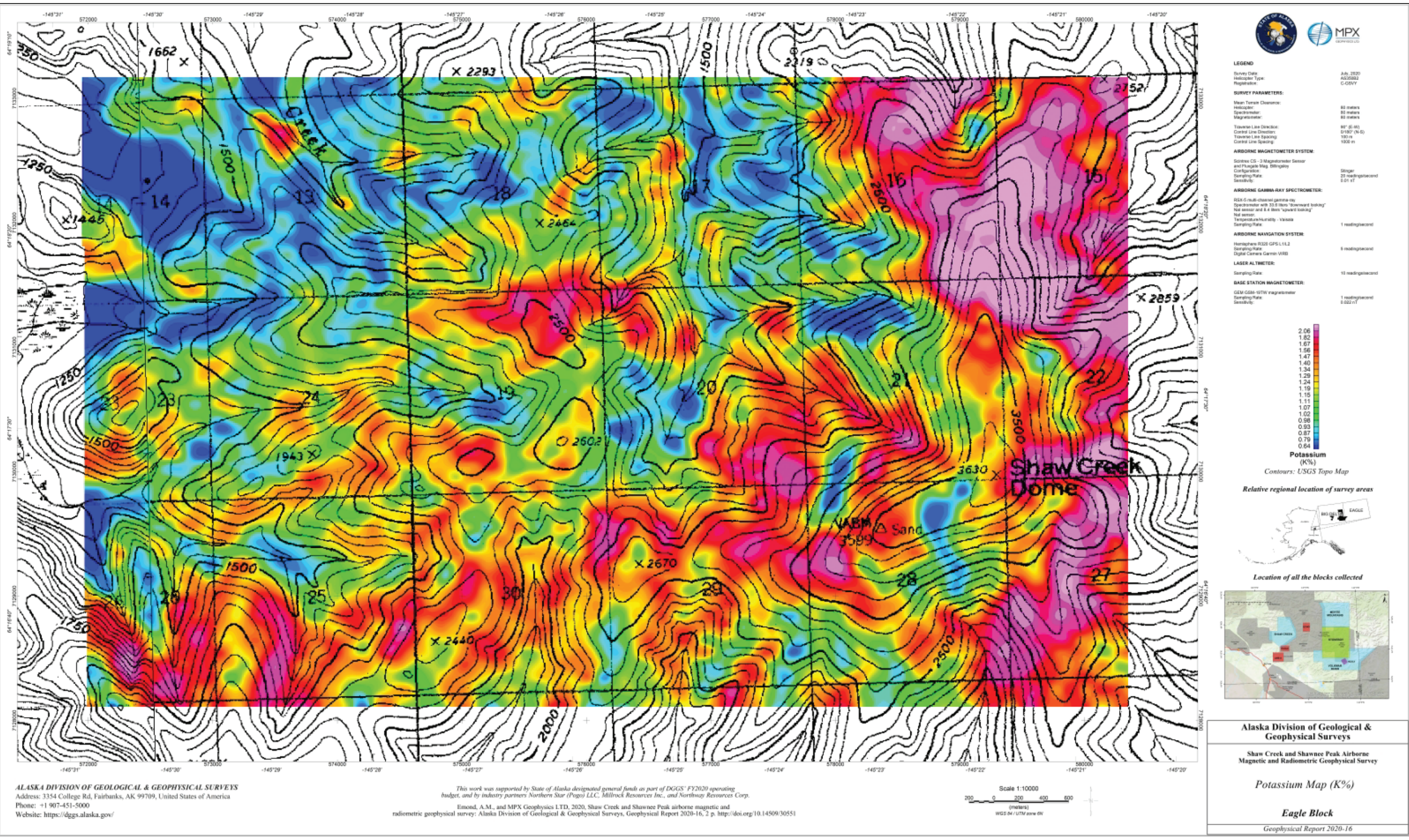




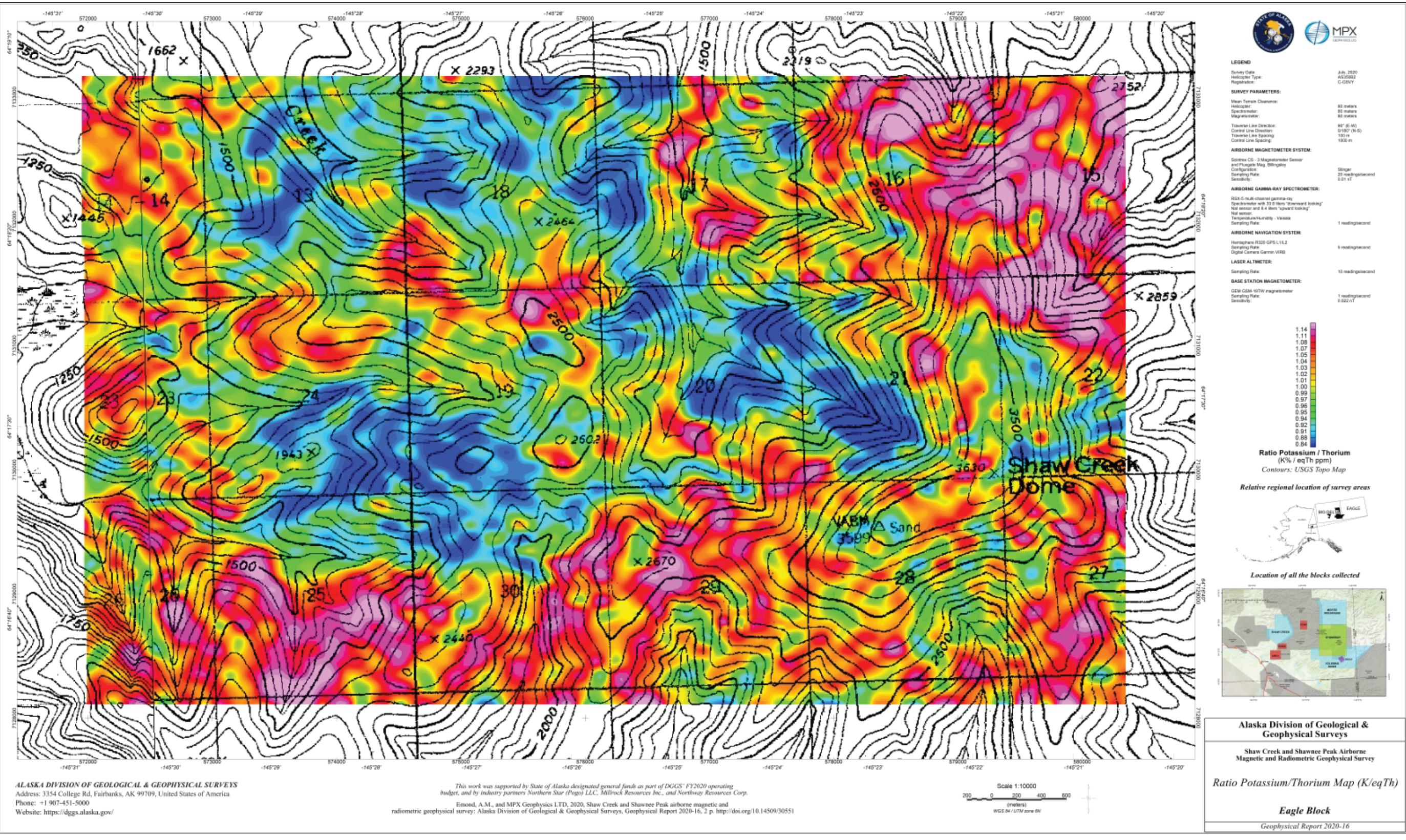




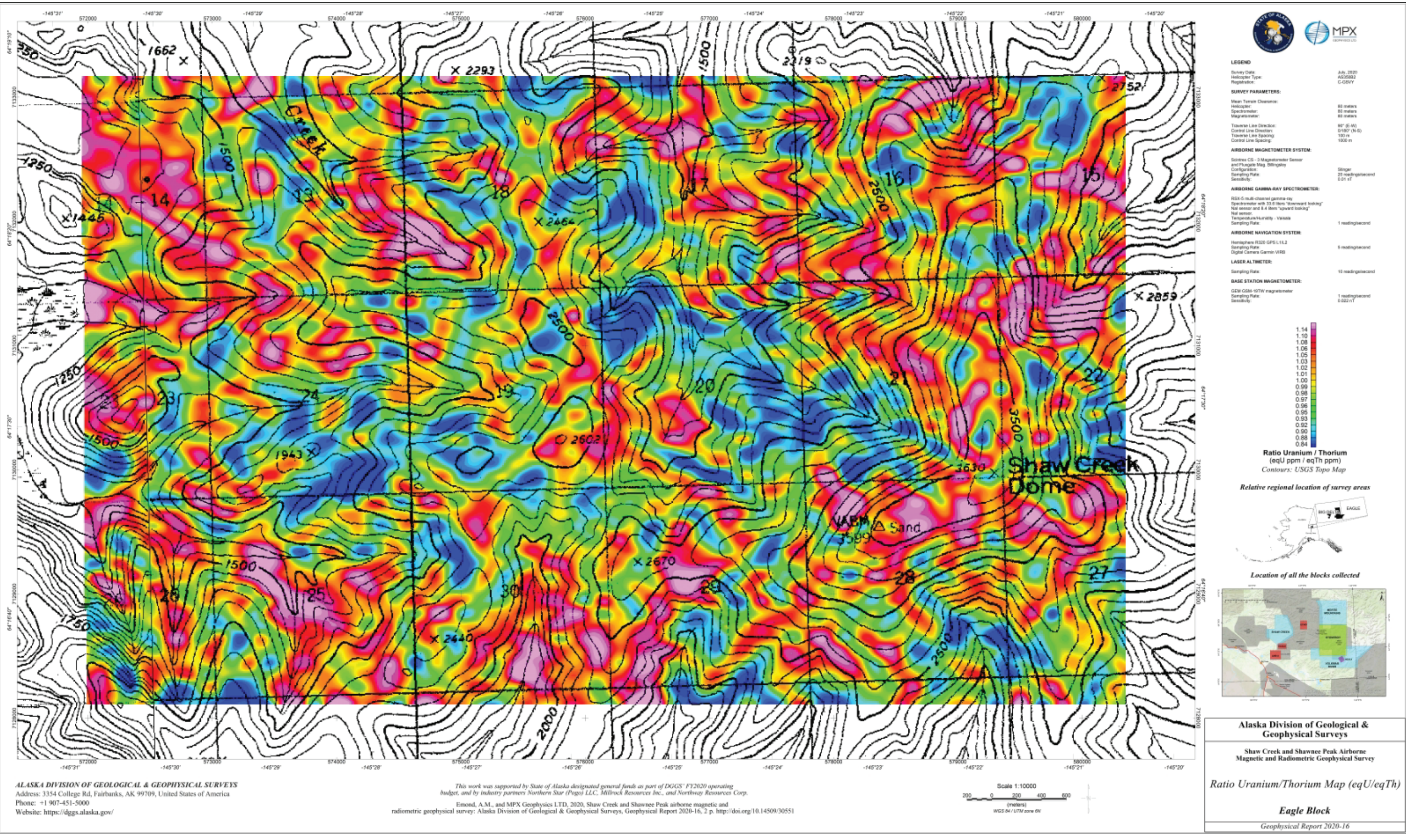




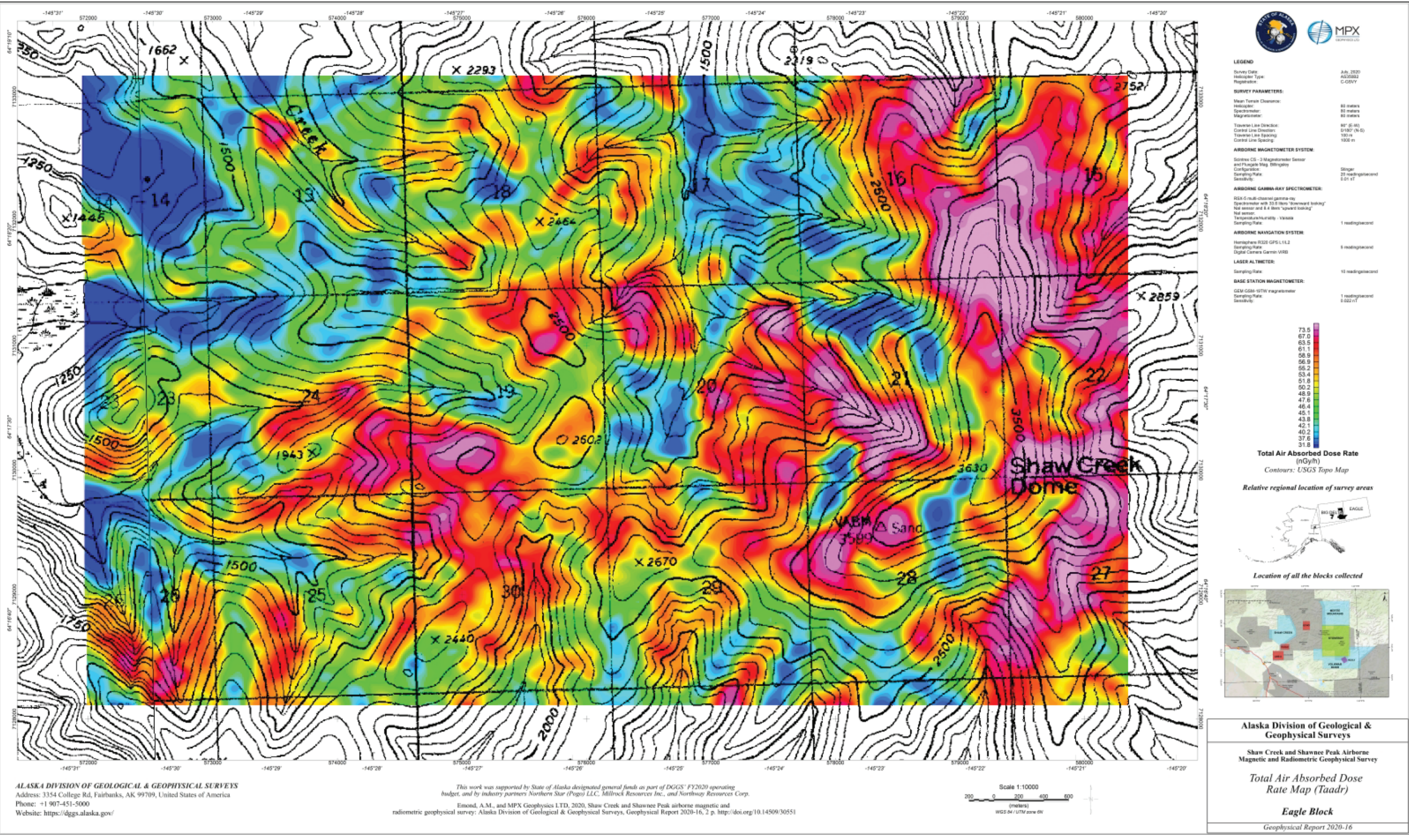




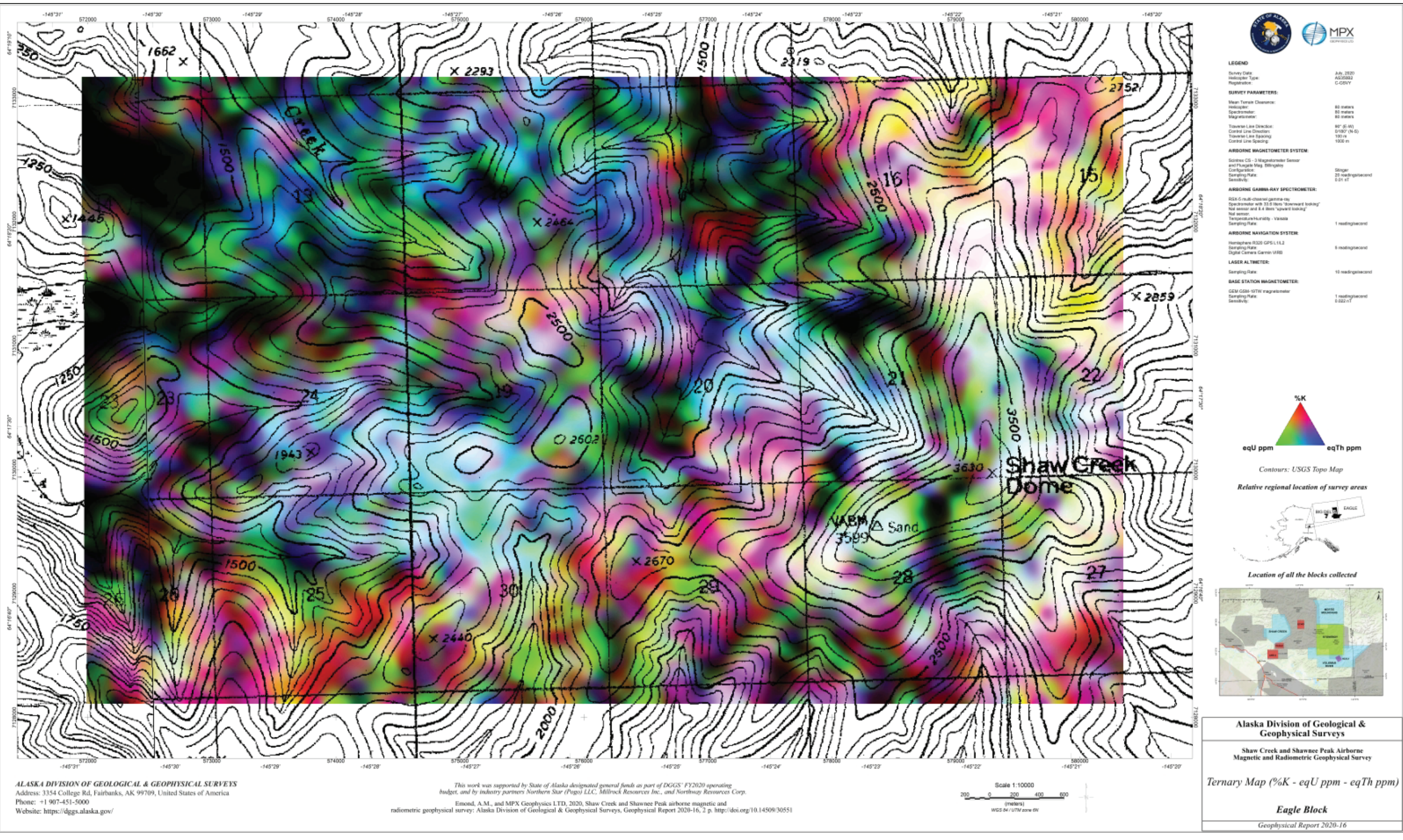




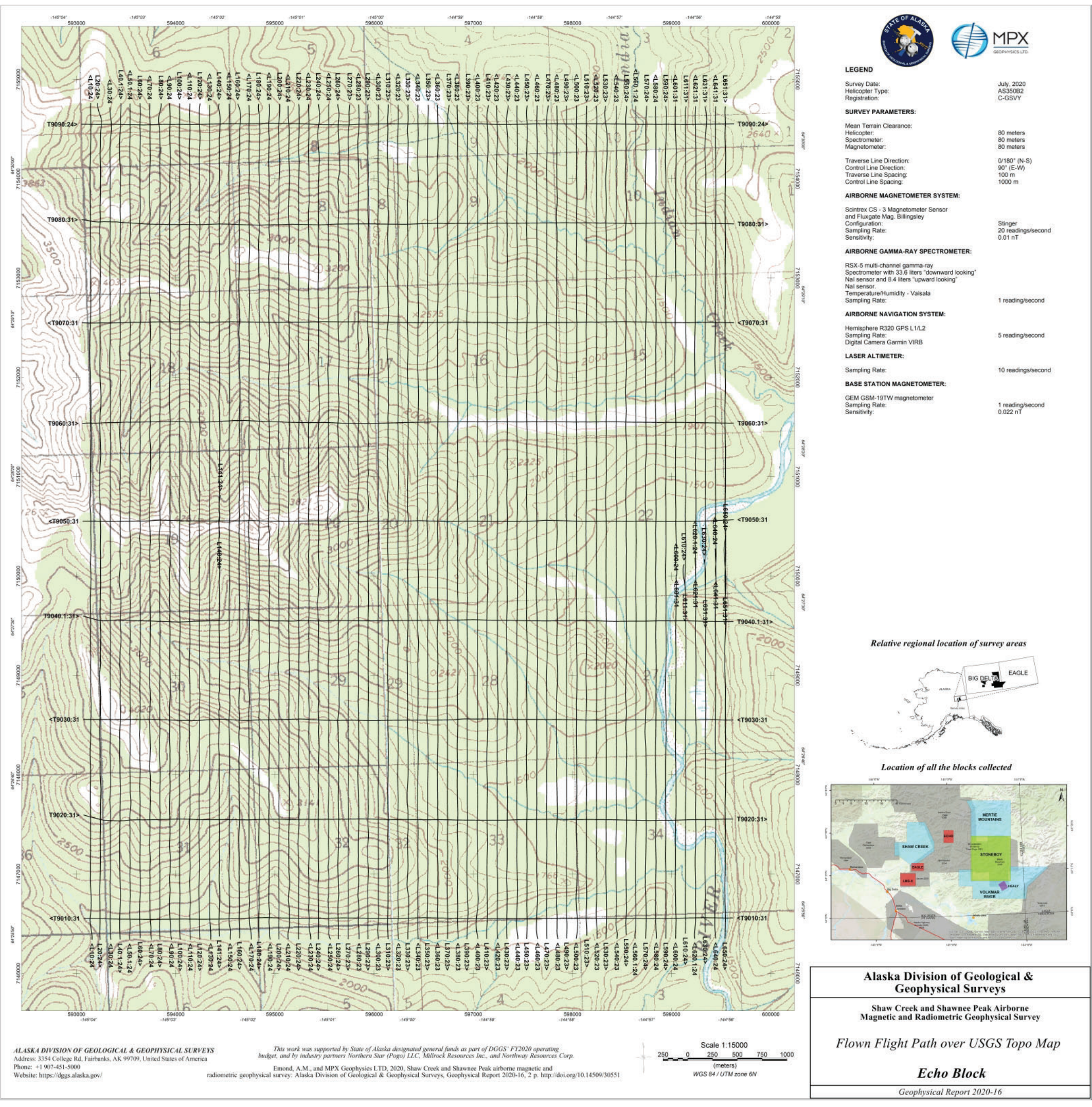


选选

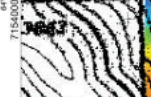

MI 1 D)

s) $\left.)_{0}\right) \ln _{x \rightarrow 032}$

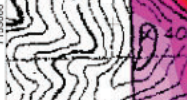

2)

$511(3$

(5) 607 (?)

(य)

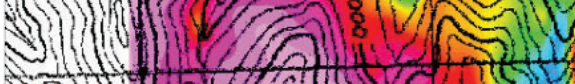

2in
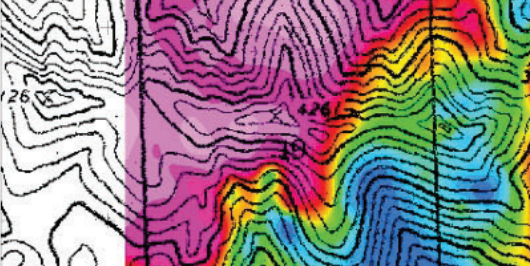

3

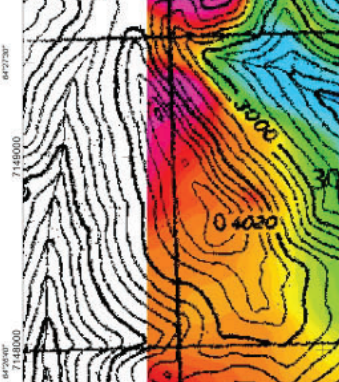

- 2 . 48
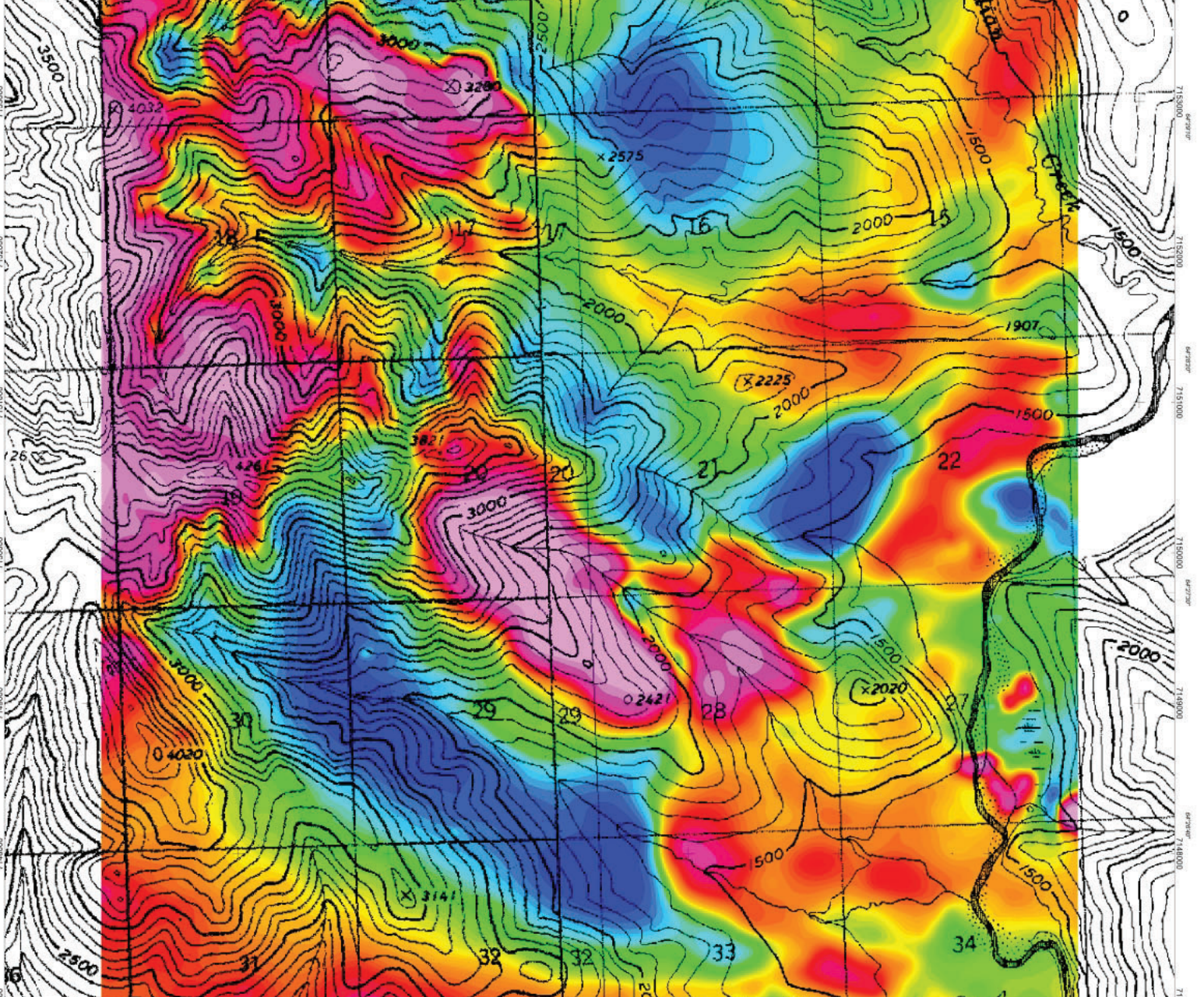

3
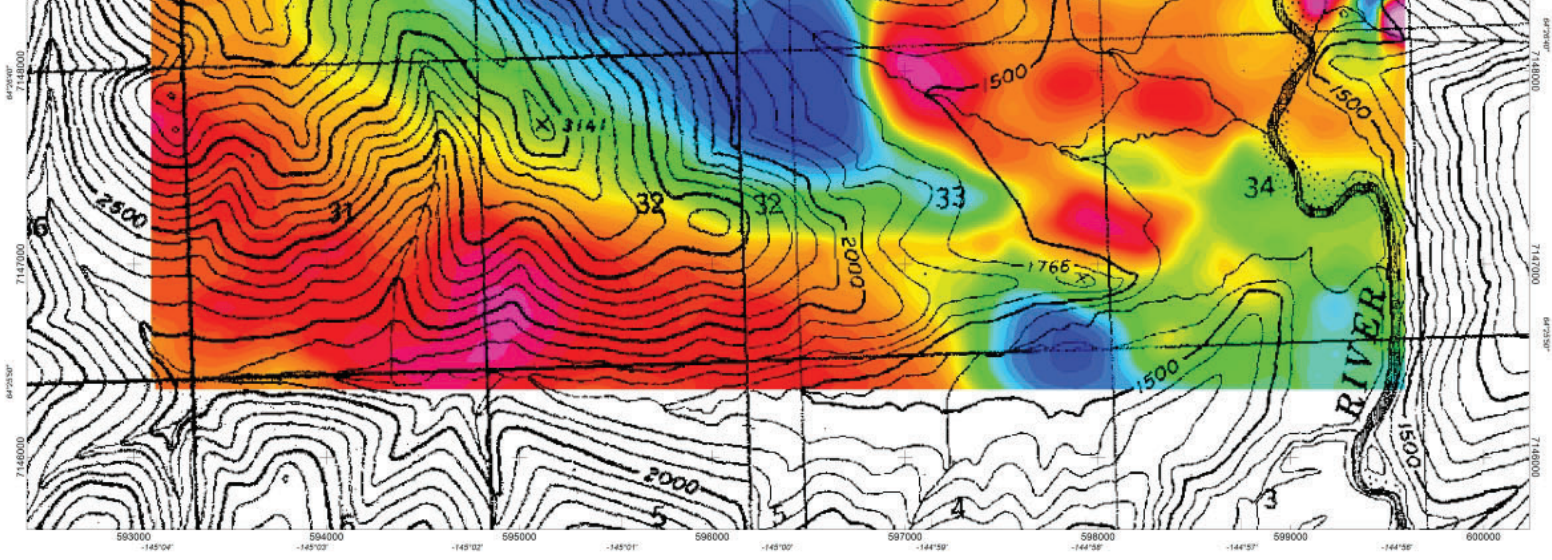

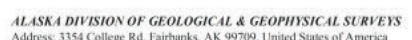

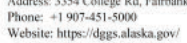

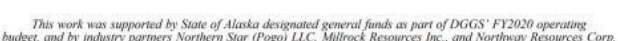

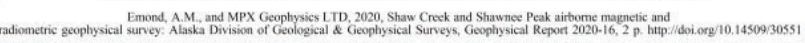

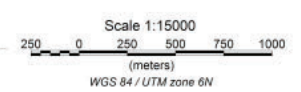

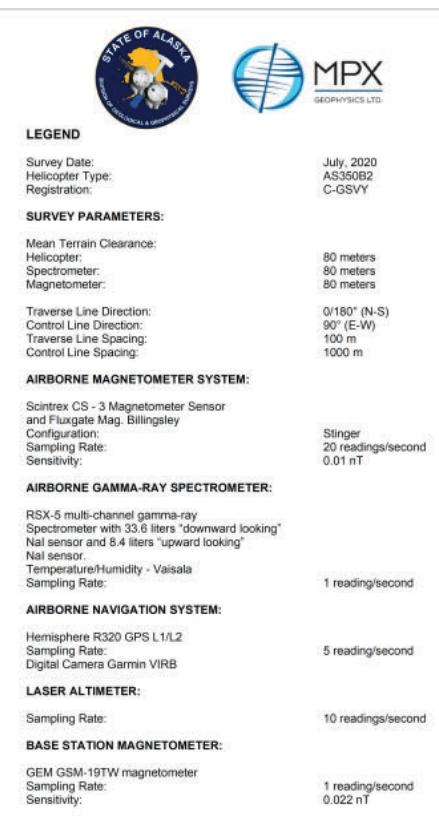

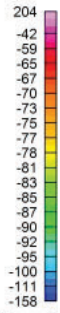

Residual Magnetic Intensity

Contours: USGS Topo Map

Relative regional location of survey areas

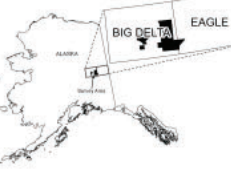

Location of all the blocks collected

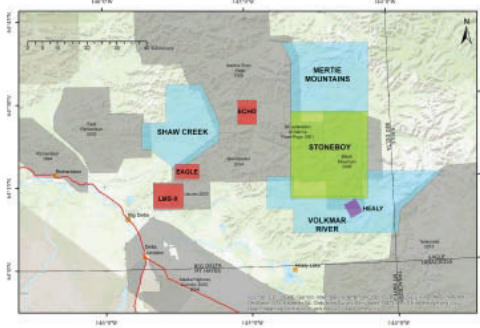

Alaska Division of Geological \& Geophysical Surveys

Shaw Creek and Shawnee Peak Airborne
Magnetic and Radiometric Geophysical Survey

Residual Magnetic Intensity Map

Echo Block 
แบ

) (1) 10 (1)

int)

(5)

5)

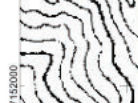

(5) 07

3

silu(fy)

政

는

6s

(L)

郭

(7) 1 ?

3
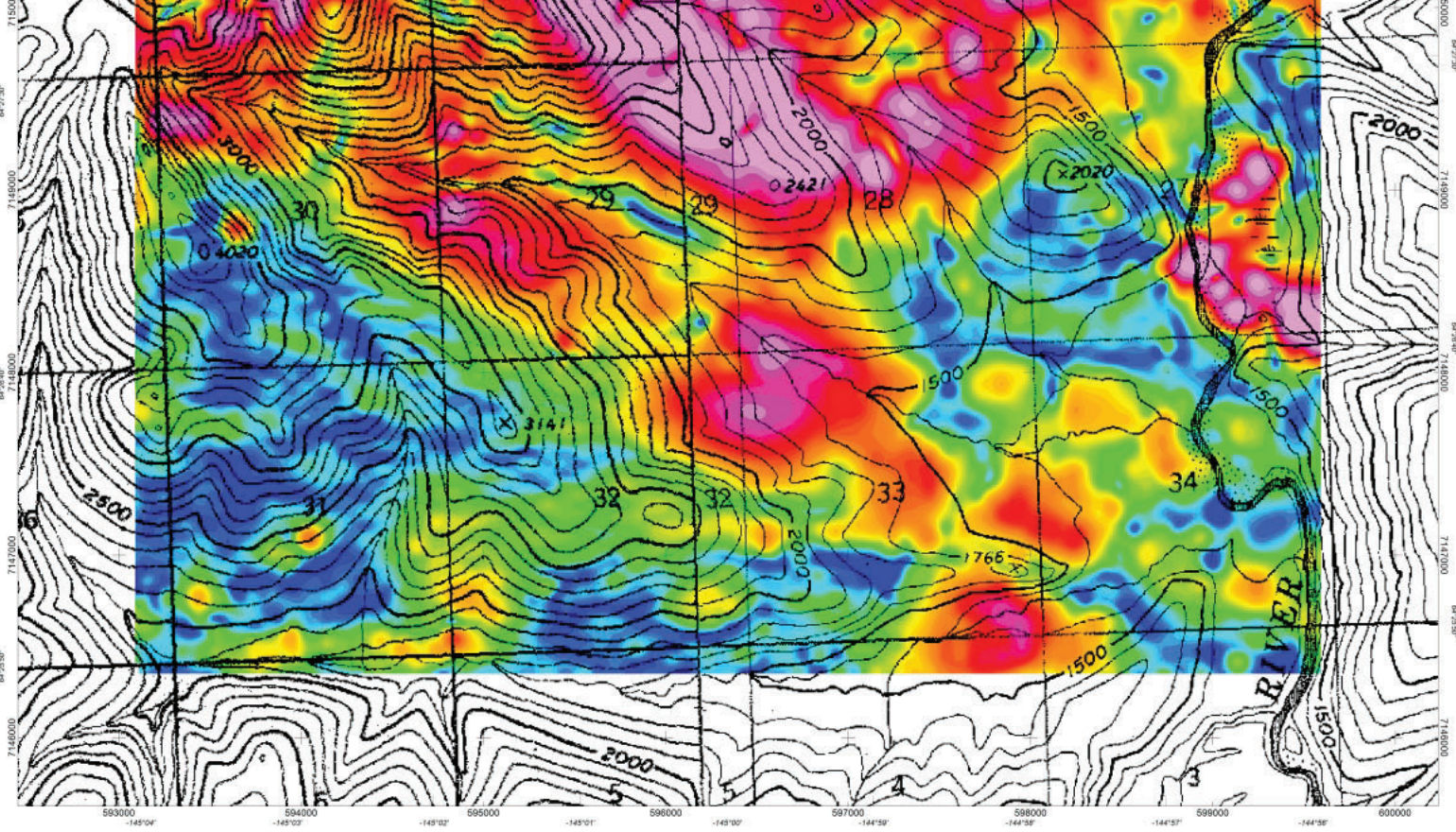

ALASKA DIVISION OF GEOLOGICAL \& GEOPHISICAL SURVETS

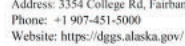

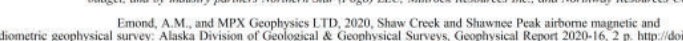

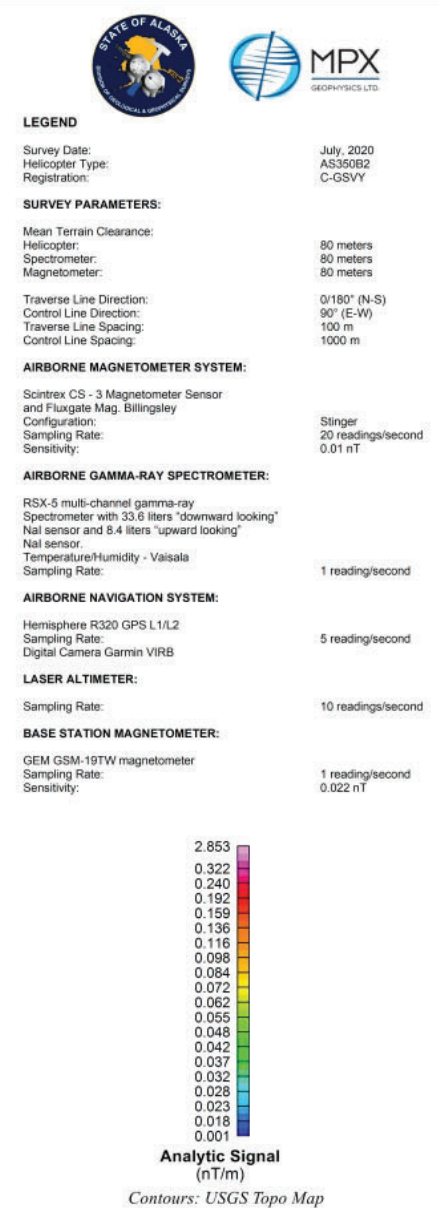

Relative regional location of survey areas

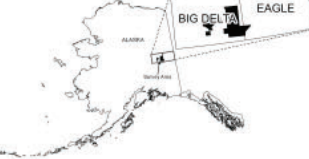

Location of all the blocks collected

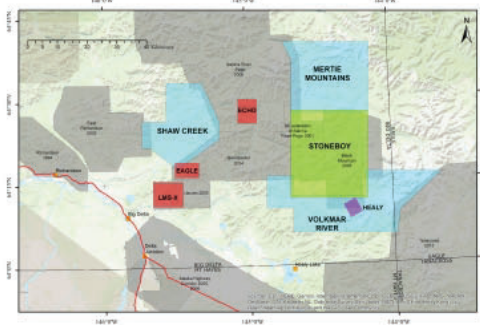

Alaska Division of Geological \&

Geophysical Surveys

Shaw Creek and Shawnee Peak Airborne
Magnetic and Radiometric Geophysical Survey

Analytic Signal Map

Echo Block 
为造 (1)
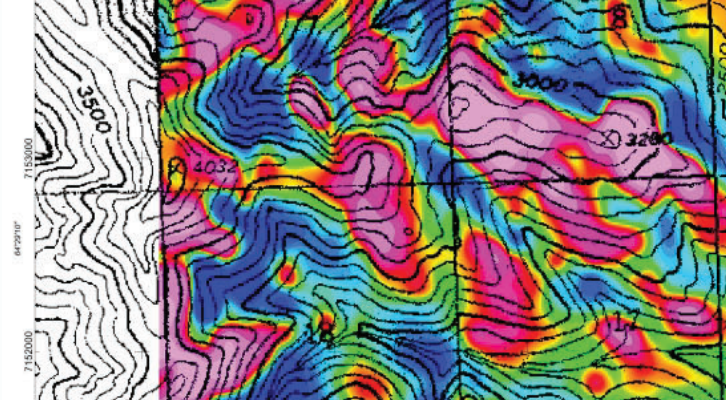

3
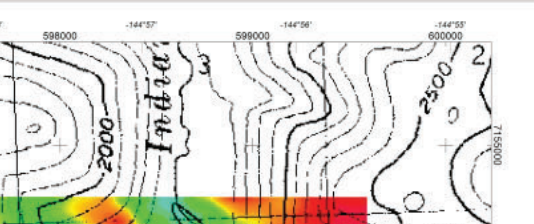

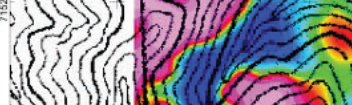

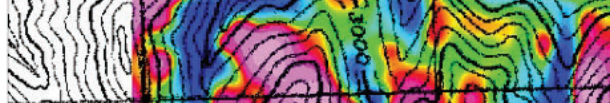

-

约

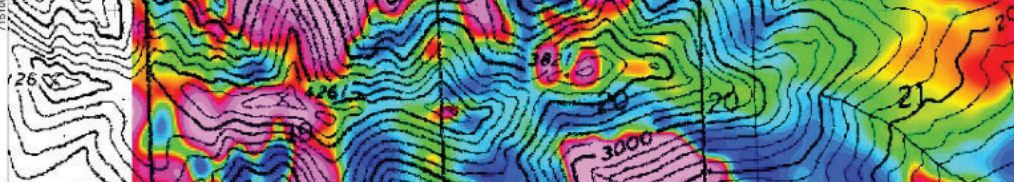

(5)

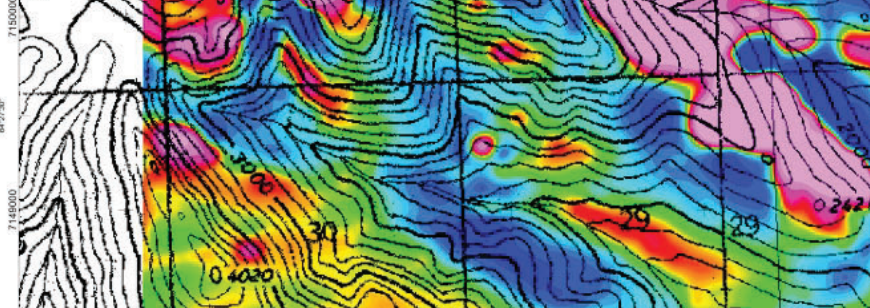

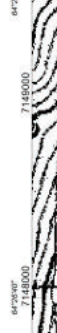

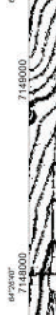

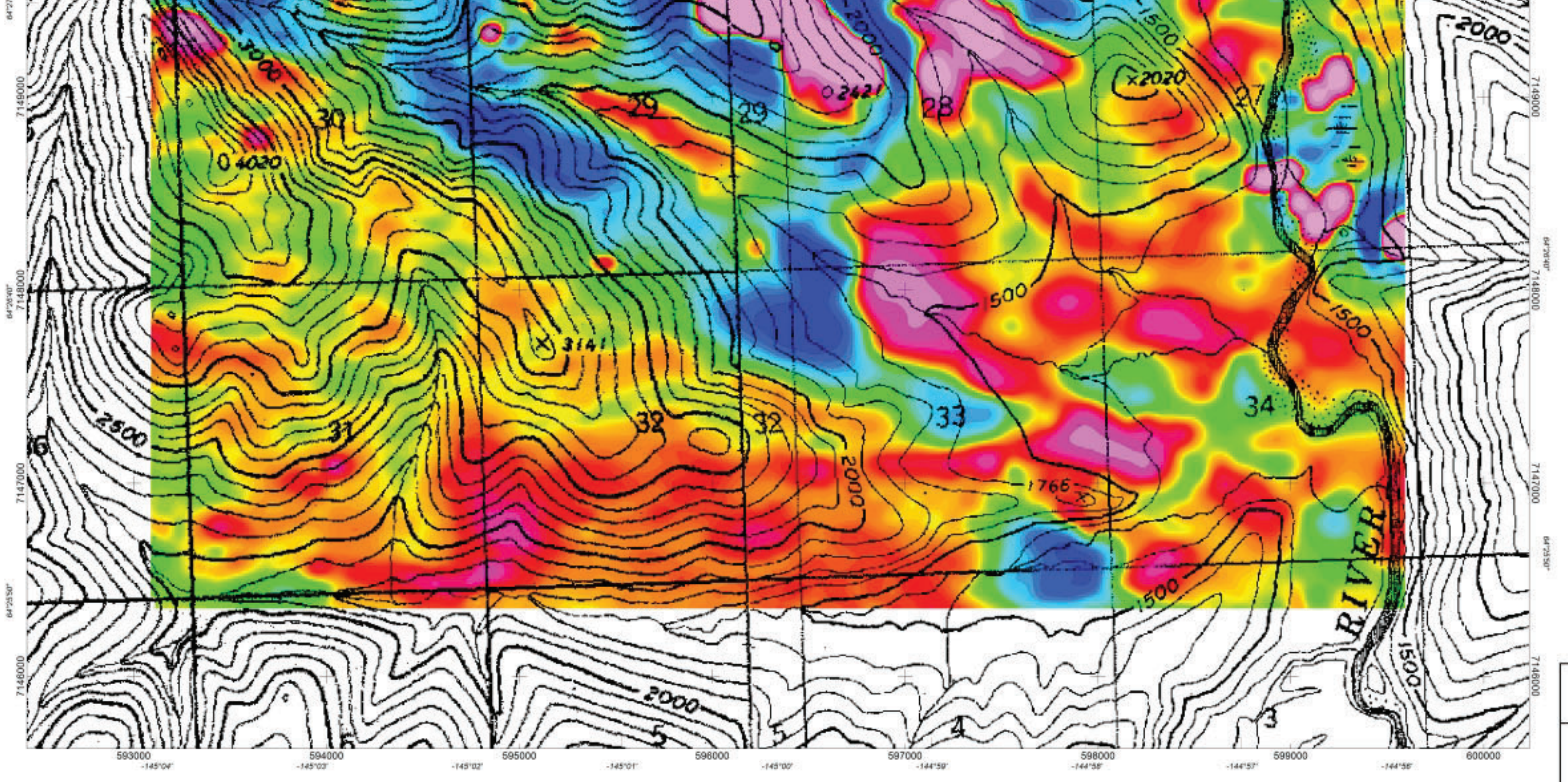

6

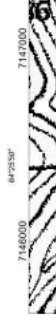
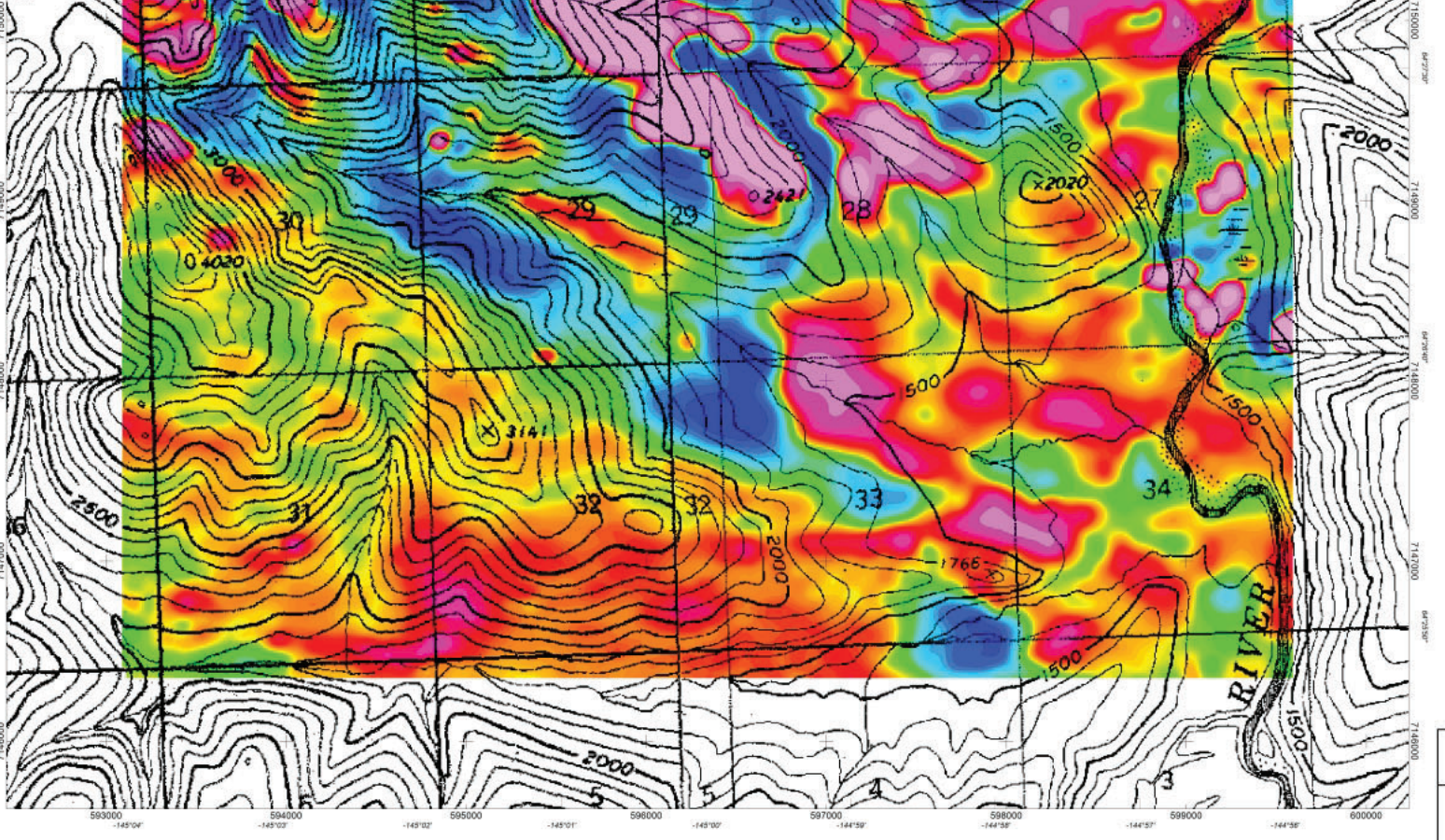

ALASKA DIVISION OF GEOLOGICAL \& GEOPHISICAL SURVETS

Phone: $+1907-451-5000$
Website: htps:/dgess.alaska.govi

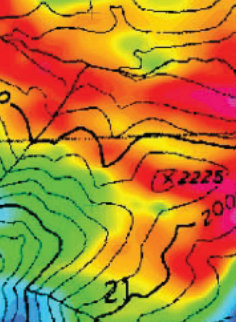

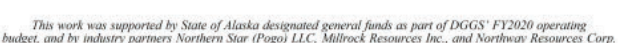

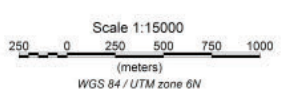

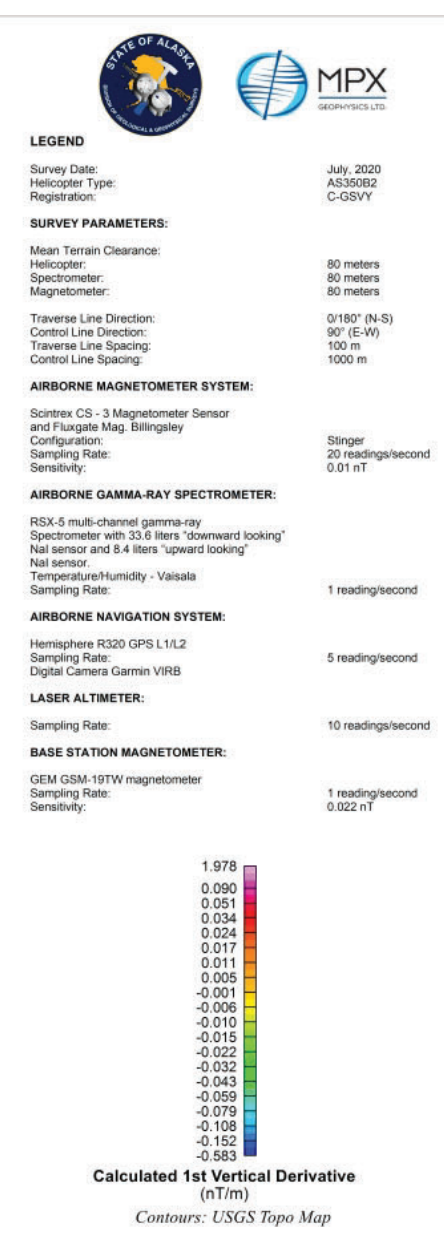

Relative regional location of survey areas

ogen

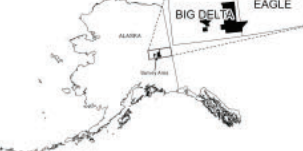

Location of all the blocks collected

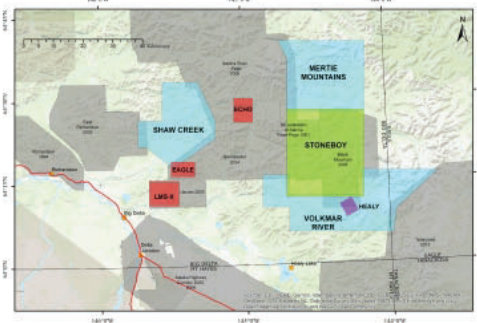

Alaska Division of Geological \& Geophysical Surveys

Shaw Creek and Shawnee Peak Airborne
Magnetic and Radiometric Geophysical Surve

Calculated 1st Vertical Derivative Map

Echo Block 


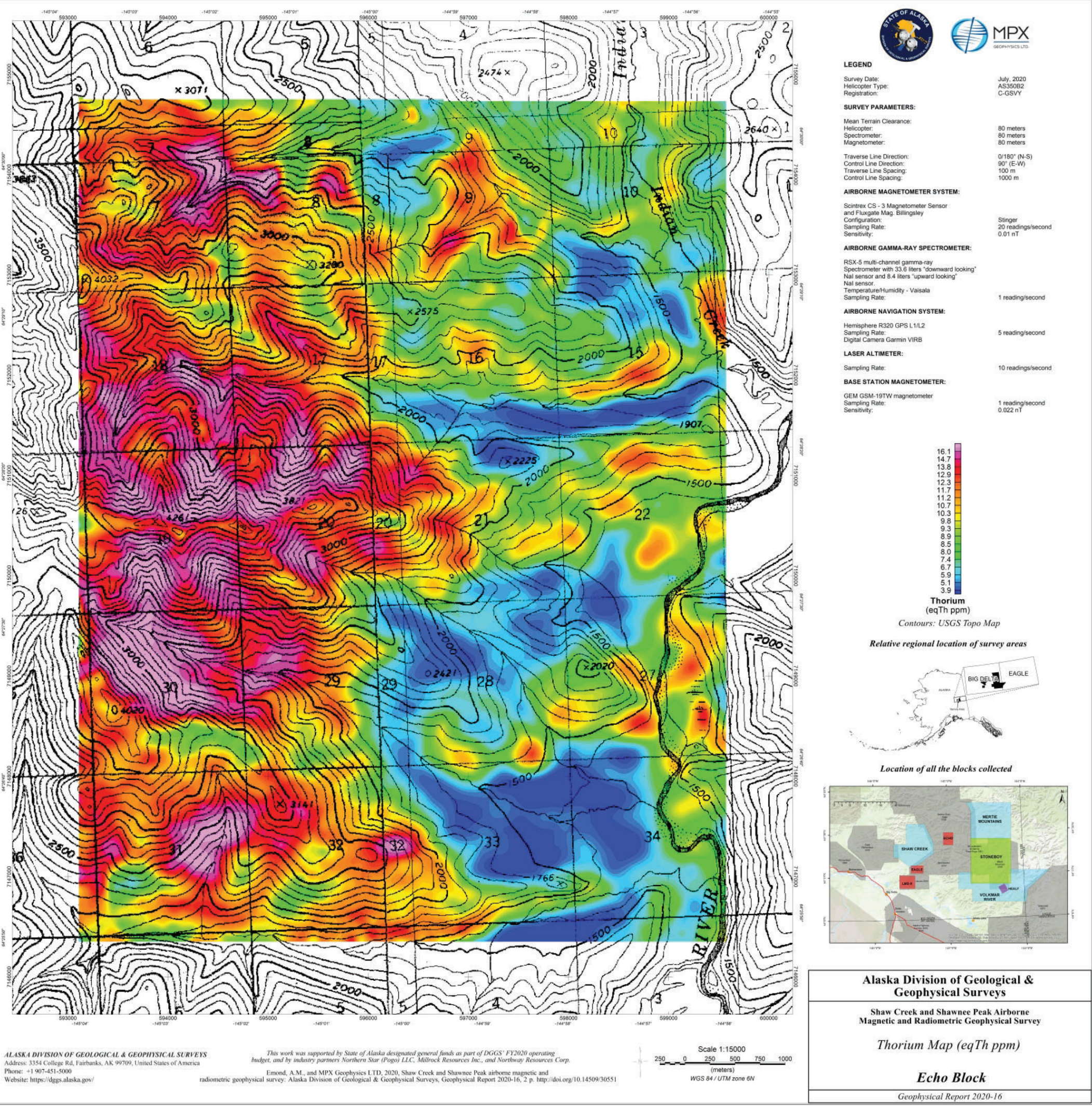




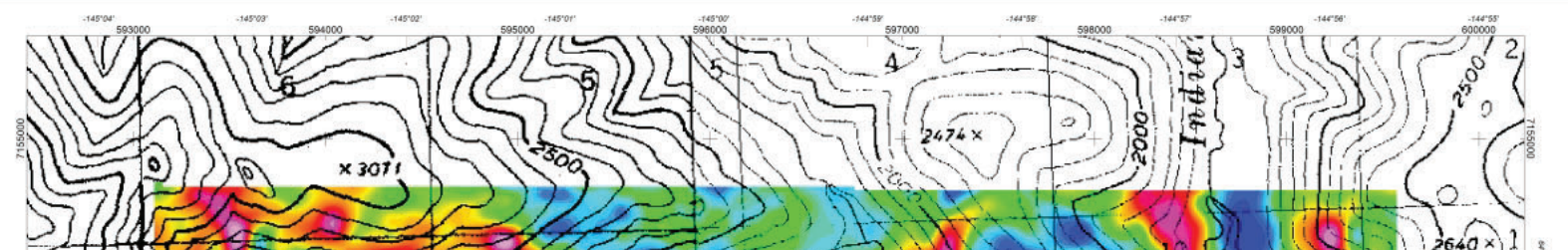
Leran

1)

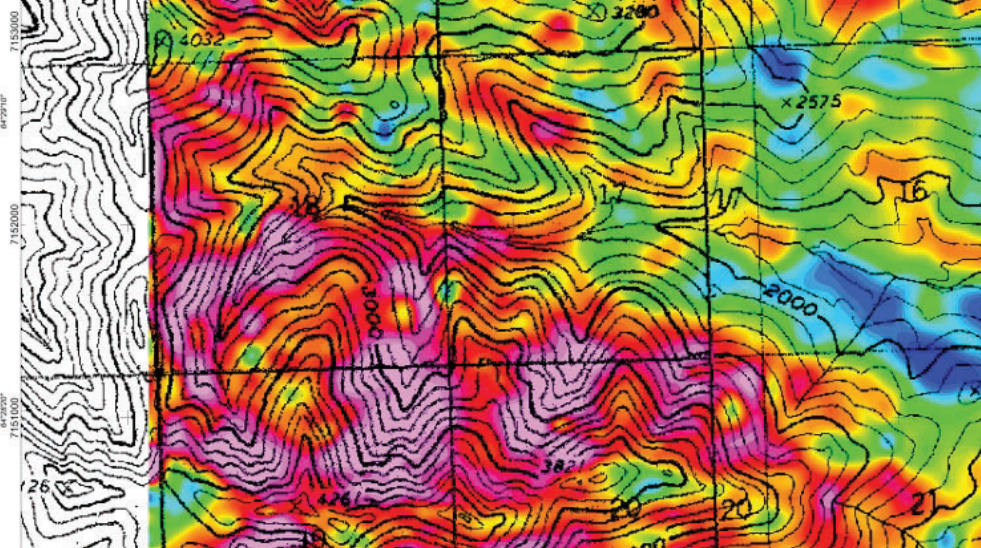

(c)

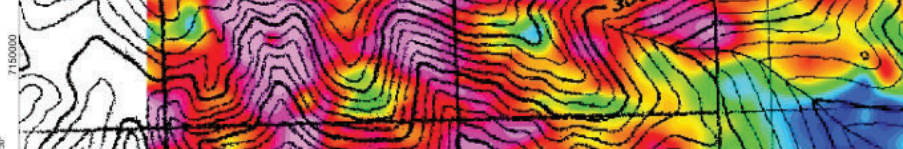
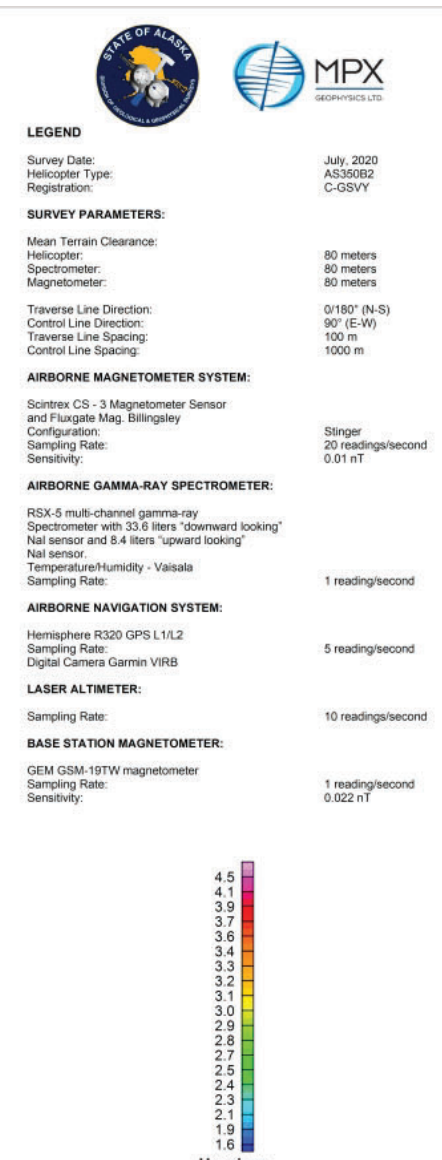

Uranium
(eqU ppm)

Contours: USGS Topo Map

Relative regional location of survey areas

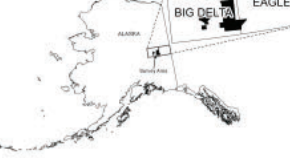

Location of all the blocks collected

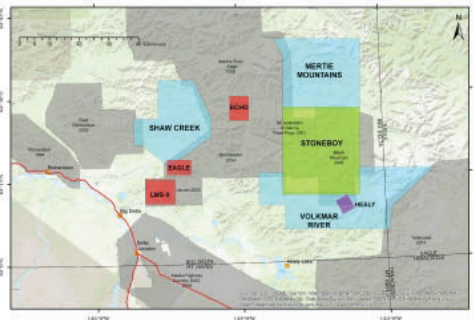

Alaska Division of Geological \&

Geophysical Surveys

Shaw Creek and Shawnee Peak Airborne
Magnetic and Radiometric Geophysical Survey

Uranium Map (eqU ppm)

Echo Block 


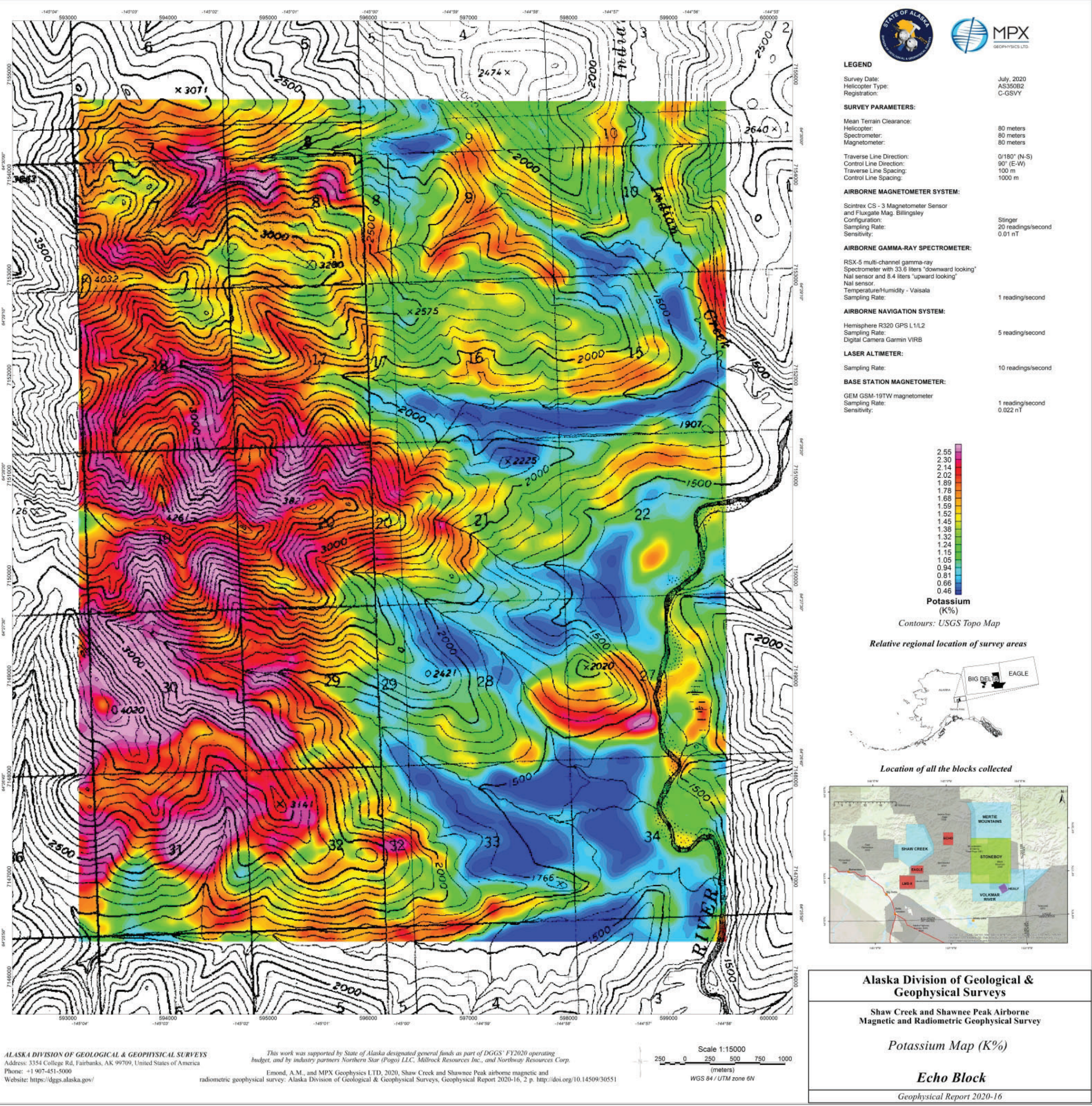


$10 / 2$

in

(10) 57 (1) $\times 300:$ (2) $\left(5^{3}\right]^{3}$

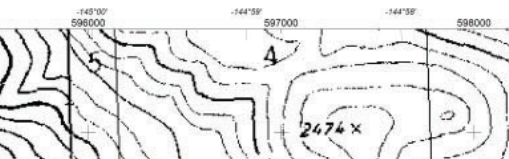

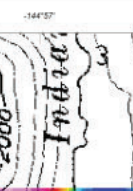

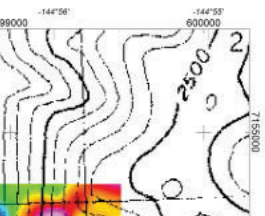

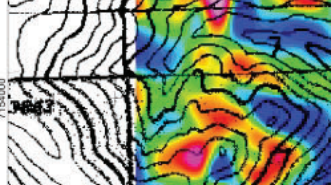

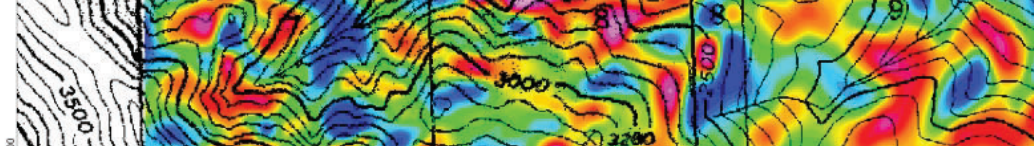

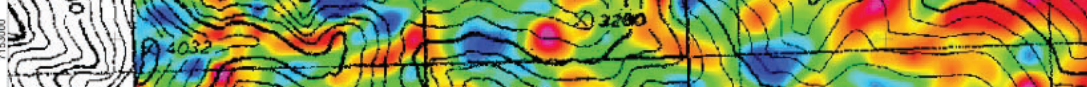

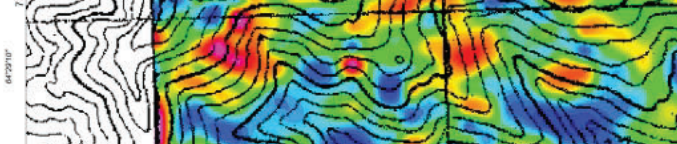

हin $(1)$

(

- 1 (6)

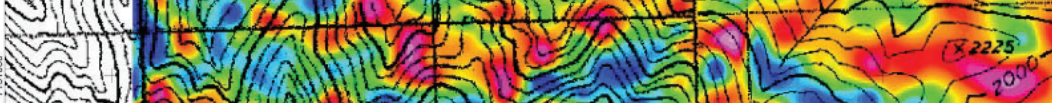
( 我

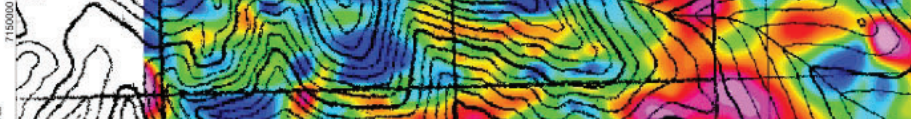

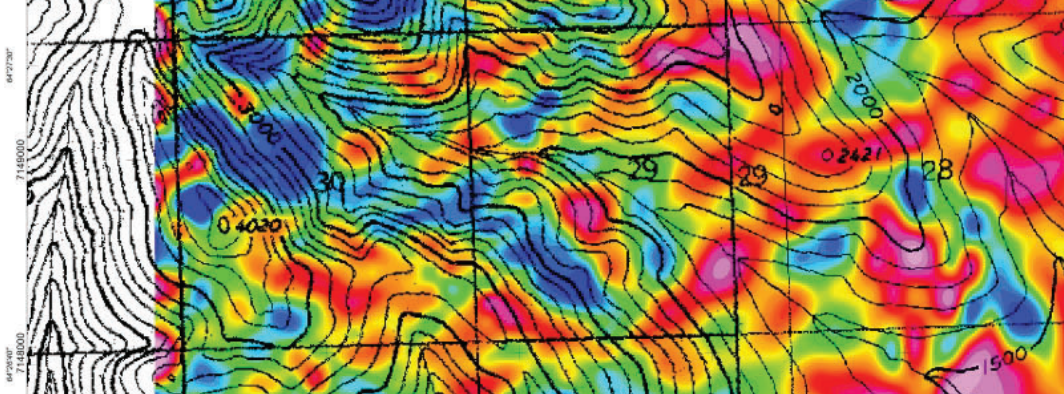

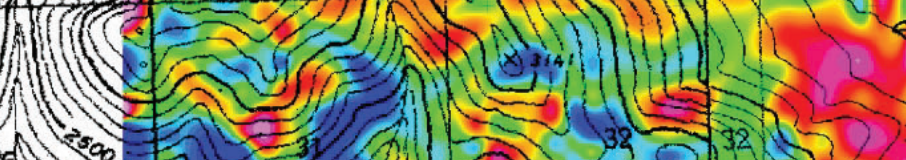

1

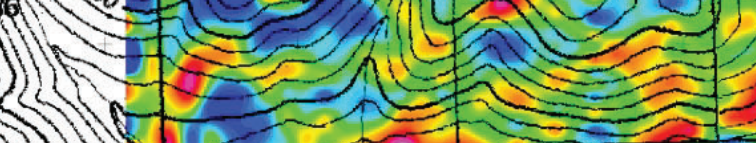

AddreSA DIVISION OF GEOLOGICAL \& GEOPIISICAL SURVERS

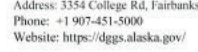

$2>0$

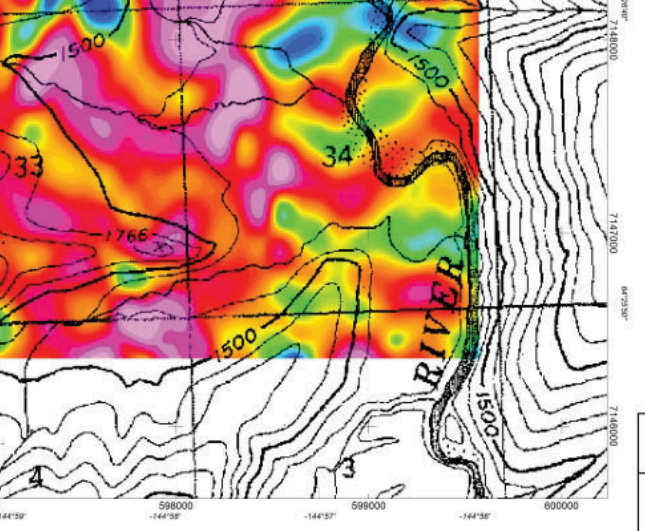

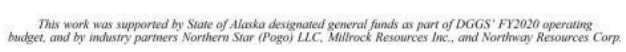

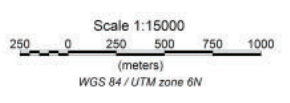

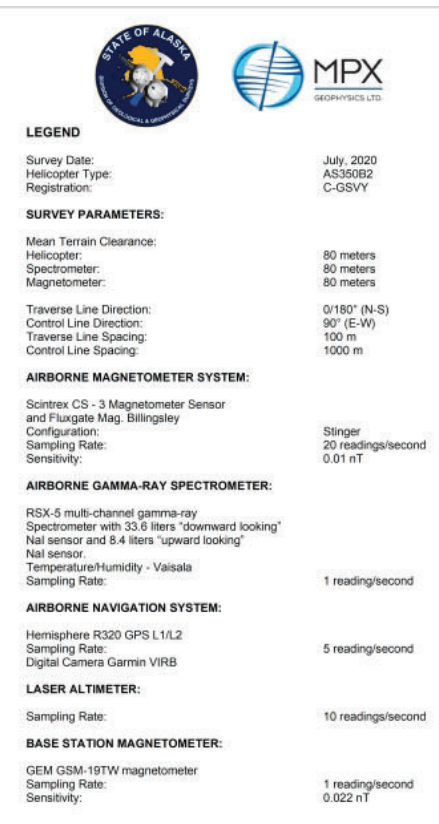
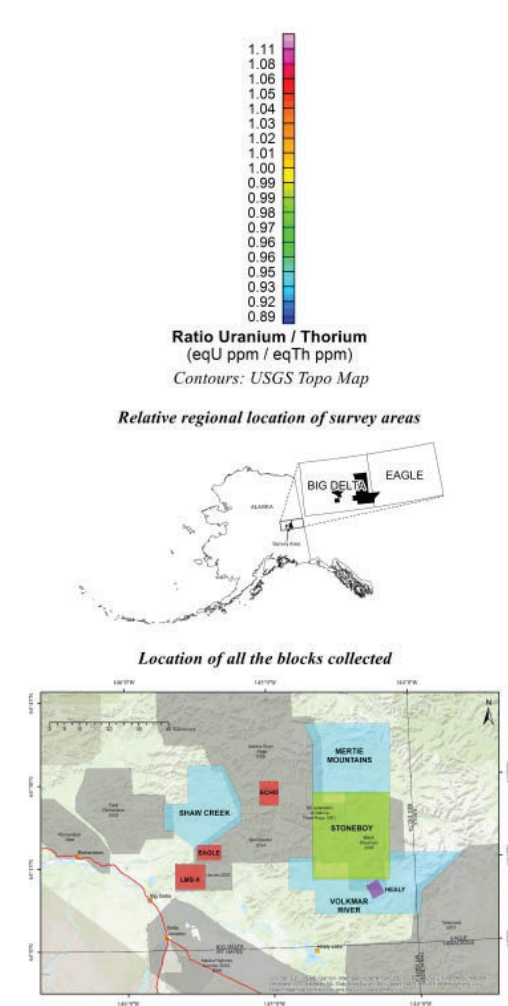

Alaska Division of Geological \& Geophysical Surveys

Shaw Creek and Shawnee Peak Airborne
Magnetic and Radiometric Geophysical Survey

Ratio Uranium/Thorium Map (eqU/eqTh)

Echo Block 


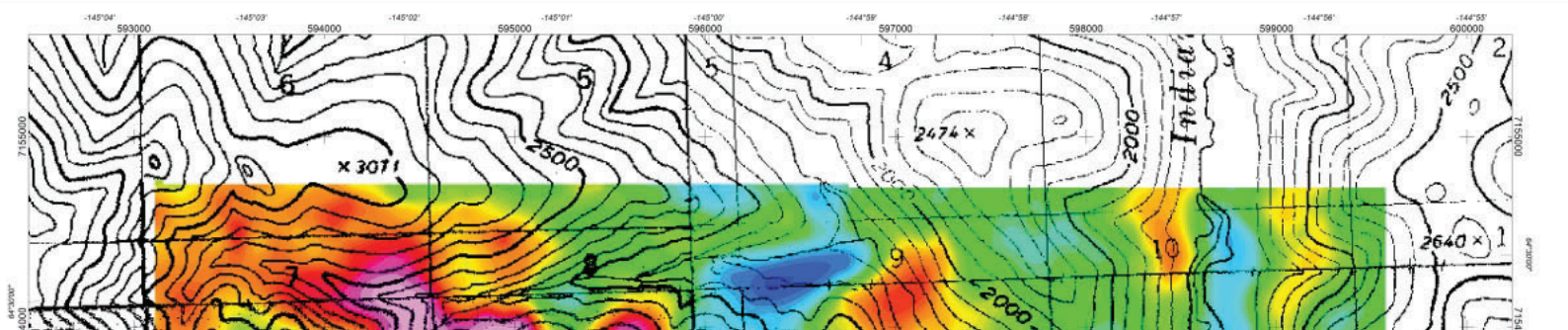

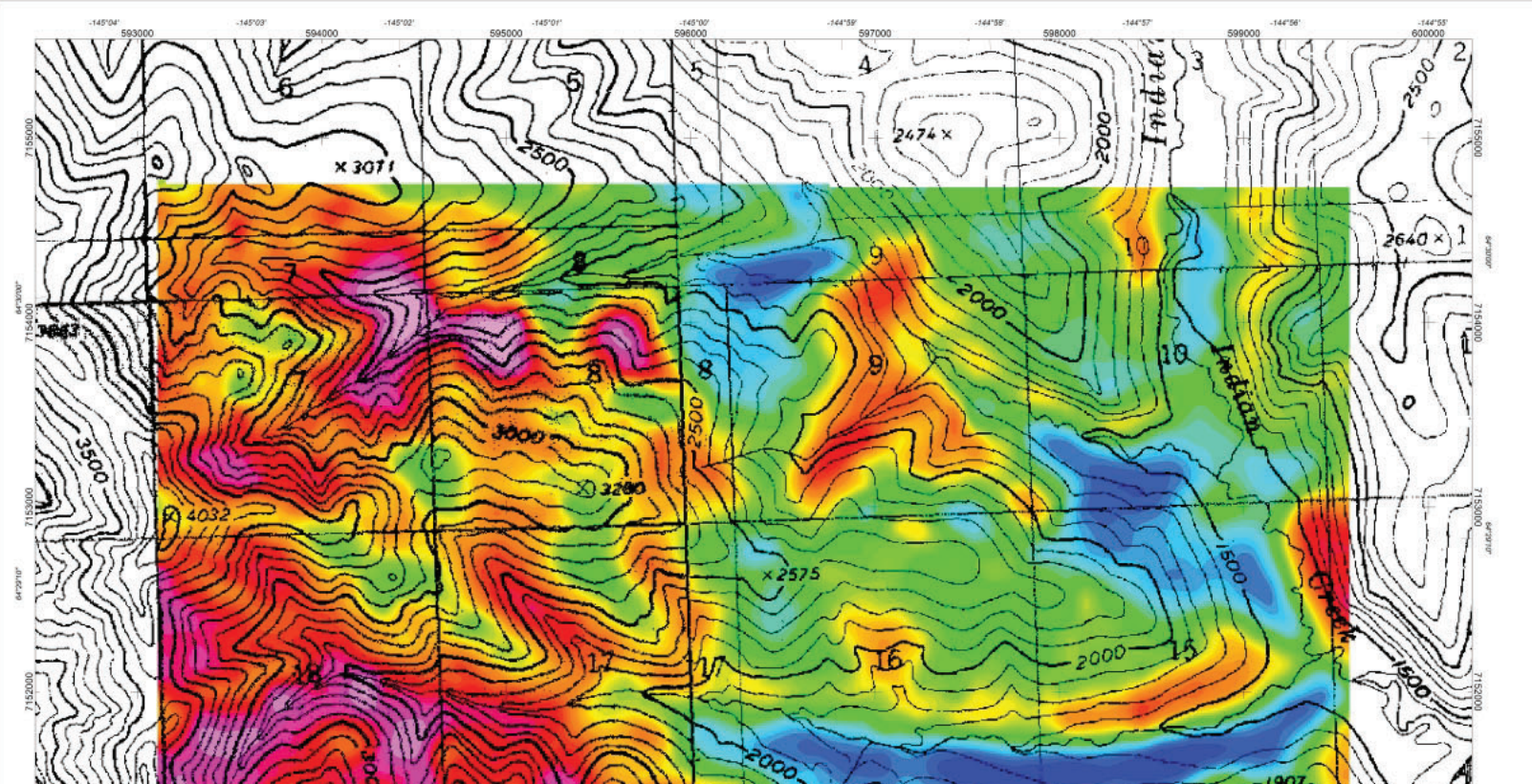

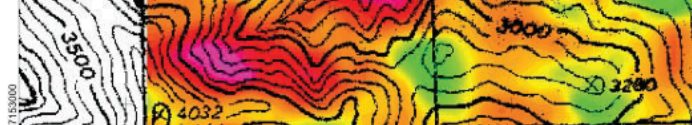

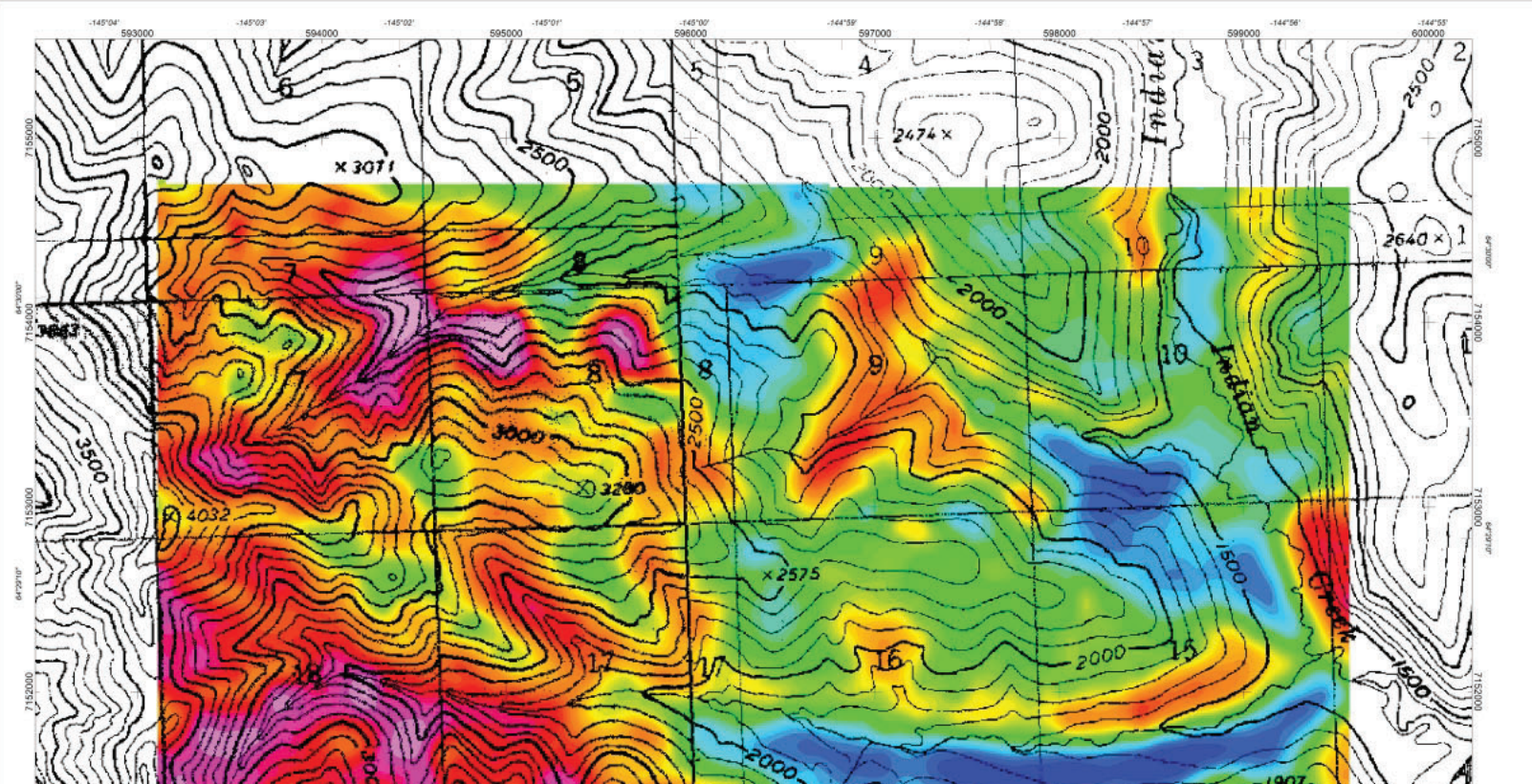

is)

(I) (a)

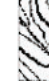

约

10

$2 \pi\left(\frac{\pi}{1}\right.$

效

3) 1 गी
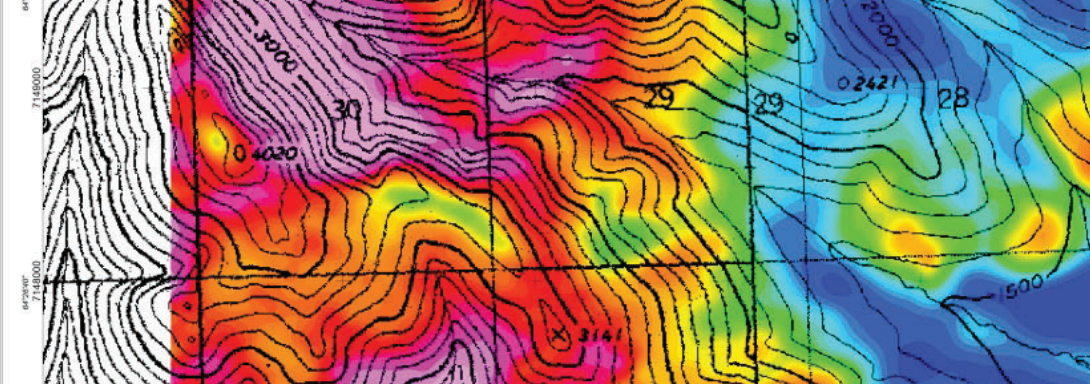

8

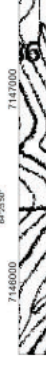

Allis

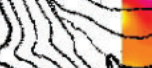

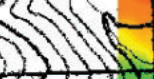

(2) 15

तn

ALASKA DIVISION OF GEOLOGICAL \& GEOPHISICAL SURVETS

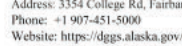
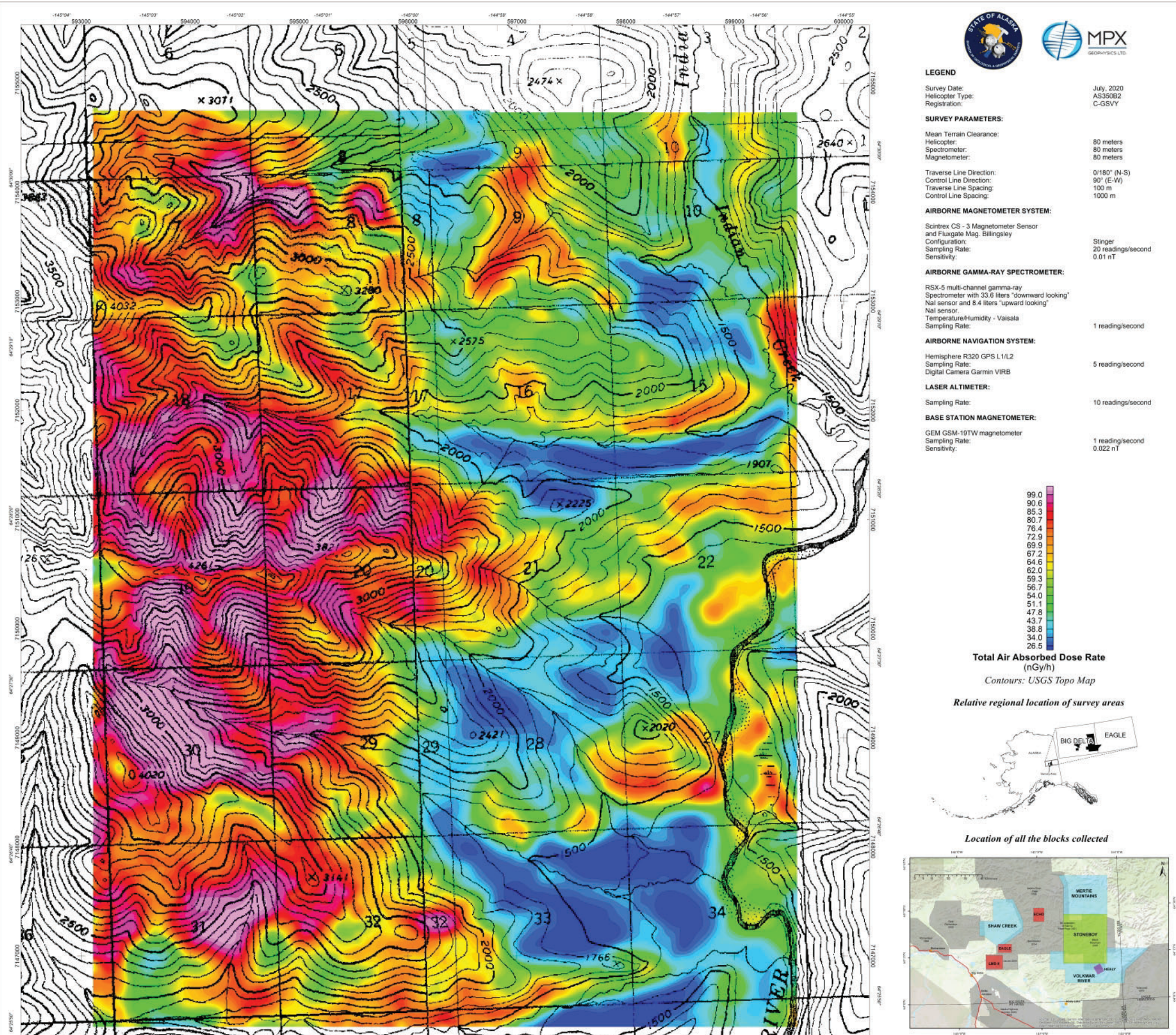

Alaska Division of Geological \& Geophysical Surveys

Shaw Creek and Shawnee Peak Airborne
Magnetic and Radiometric Geophysical Survey

Total Air Absorbed Dose Rate Map (Taadr)

Echo Block 


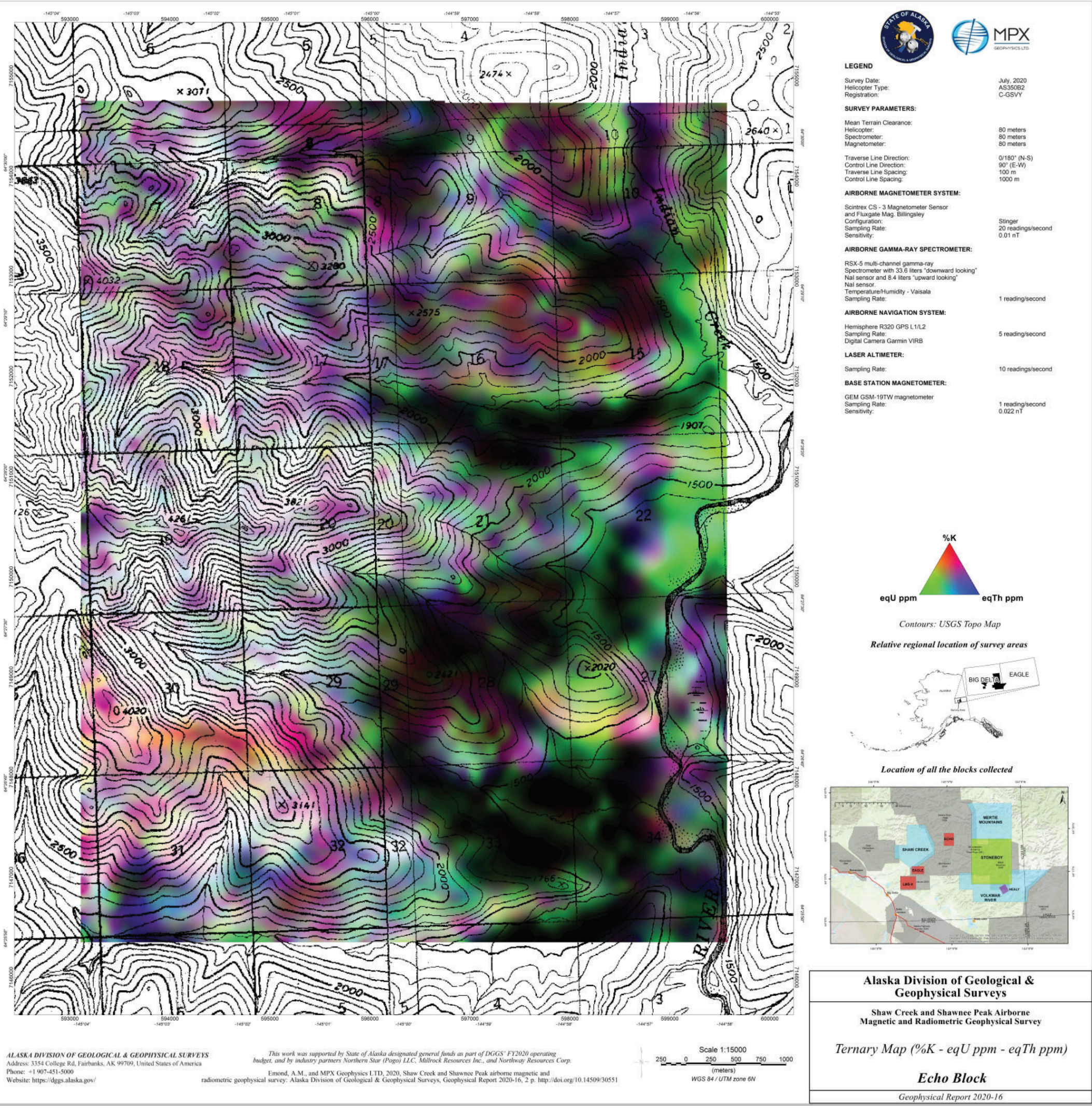




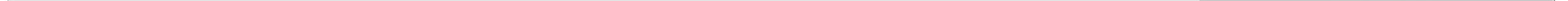




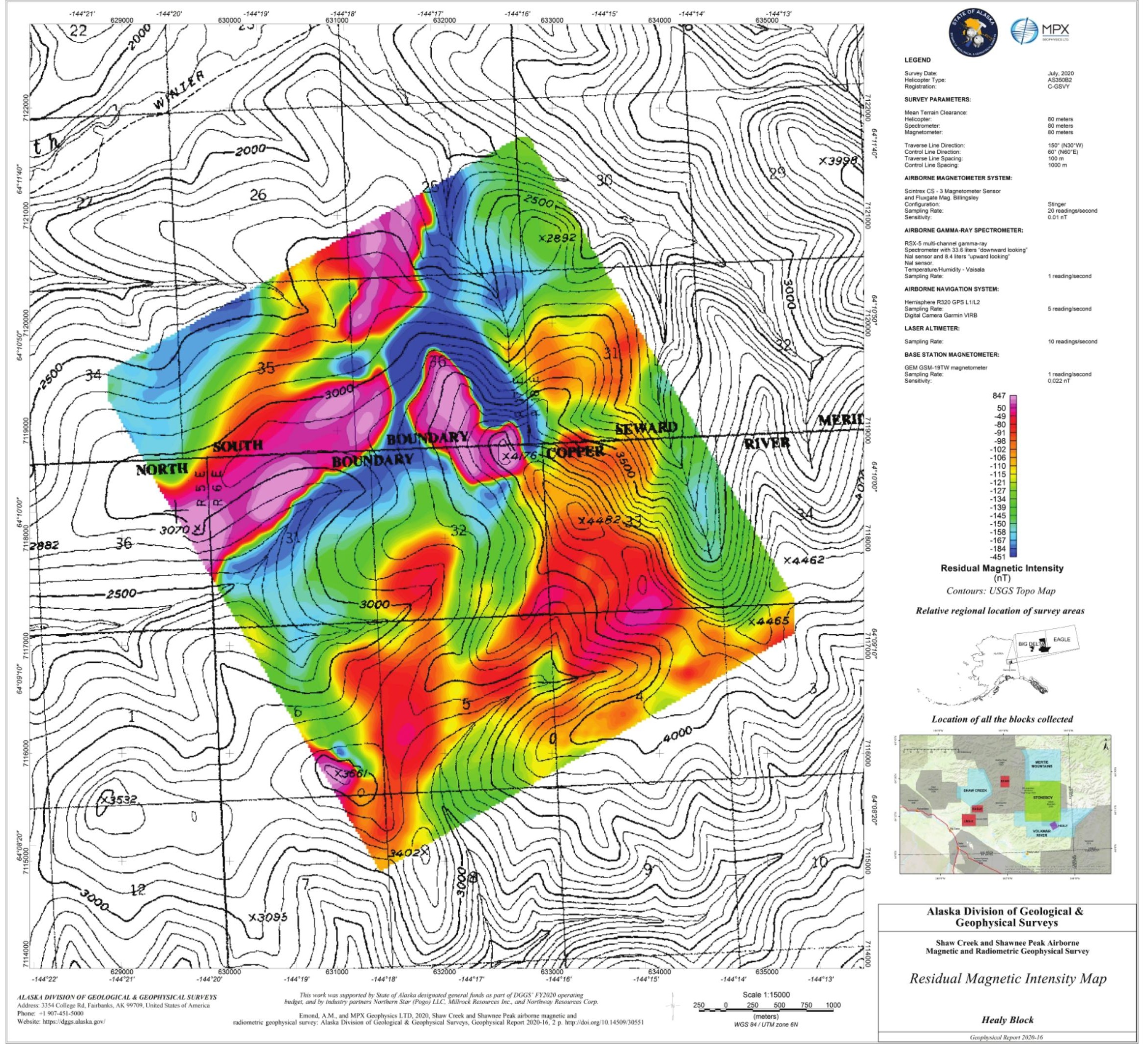




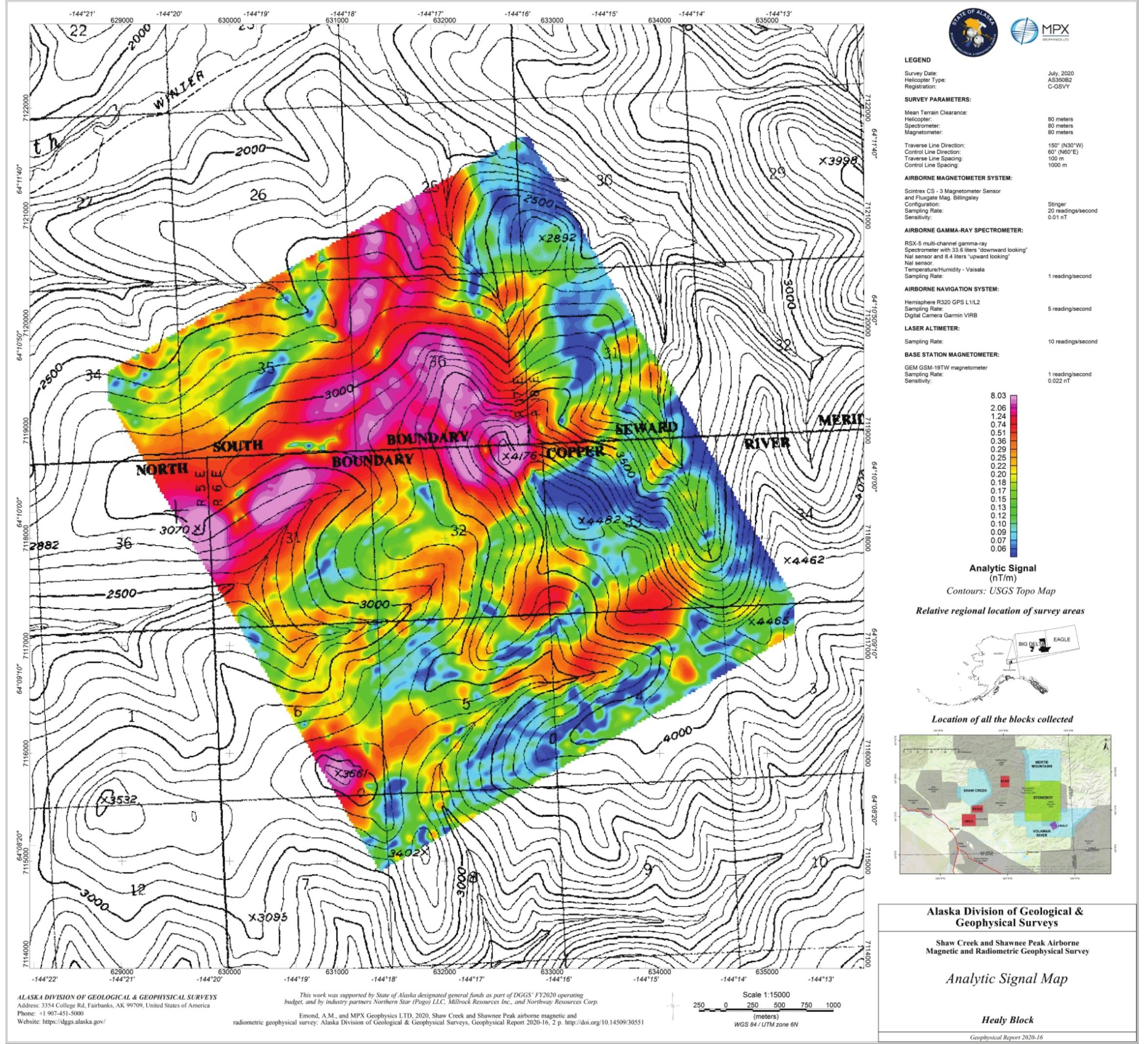




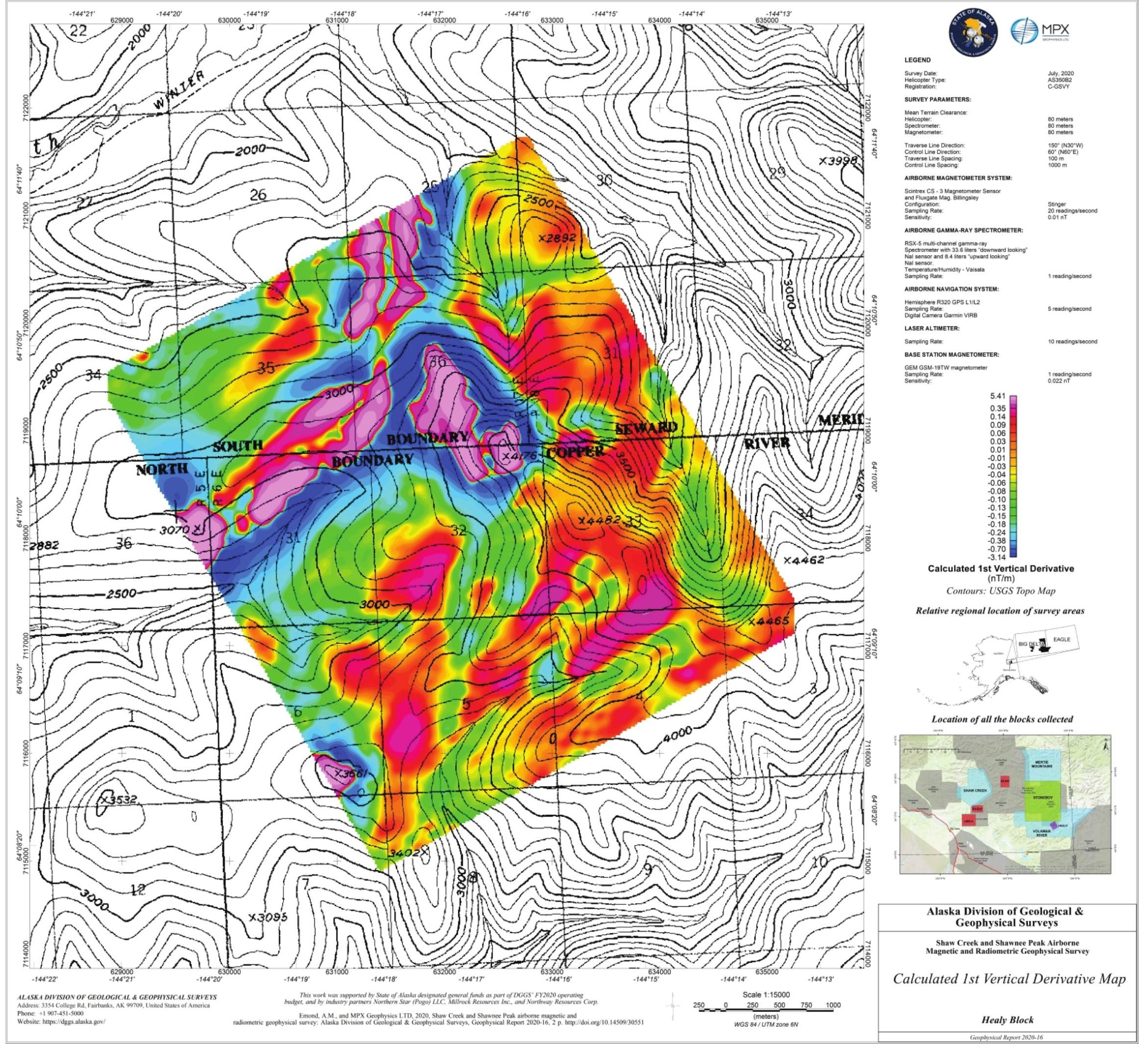




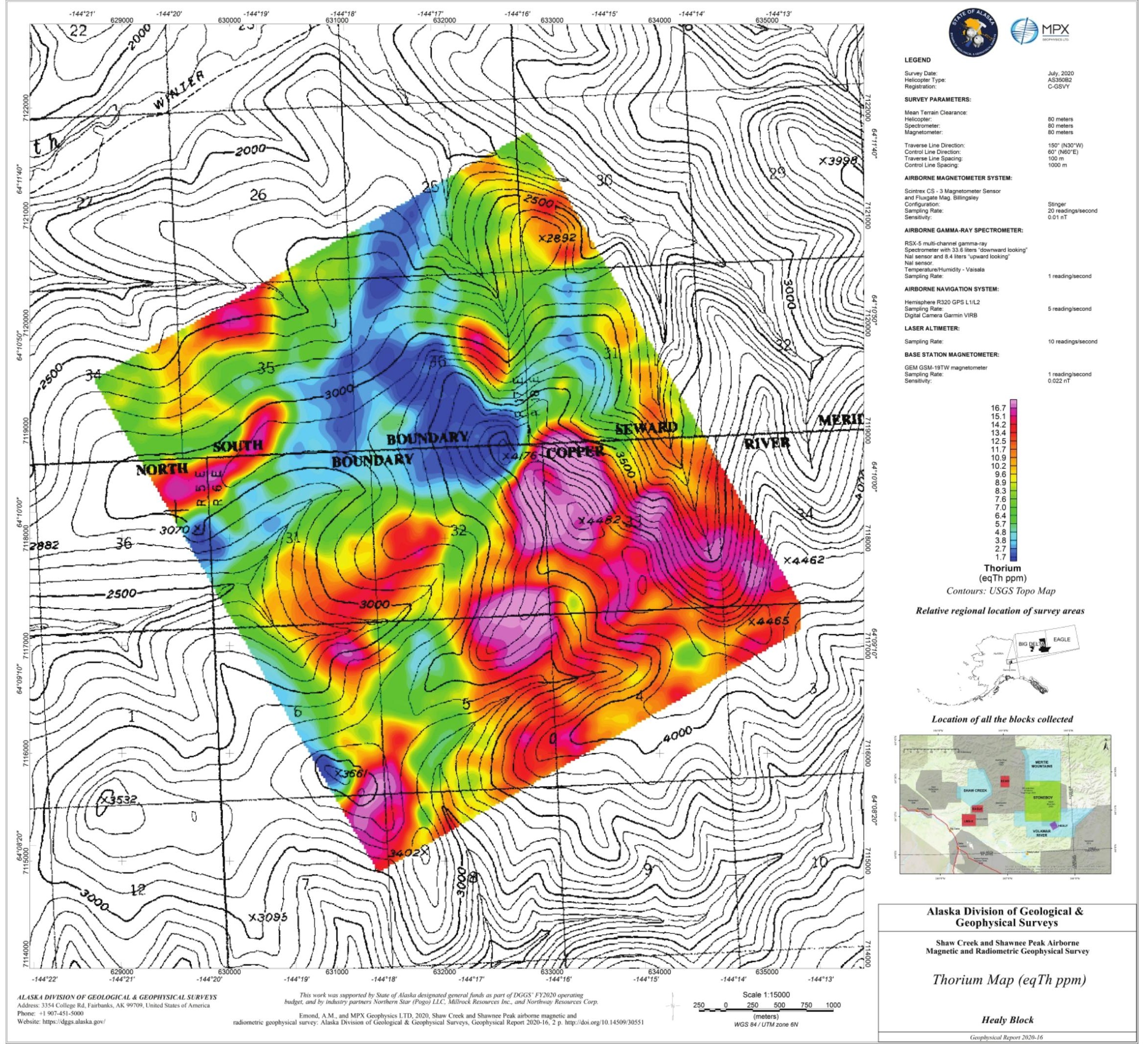




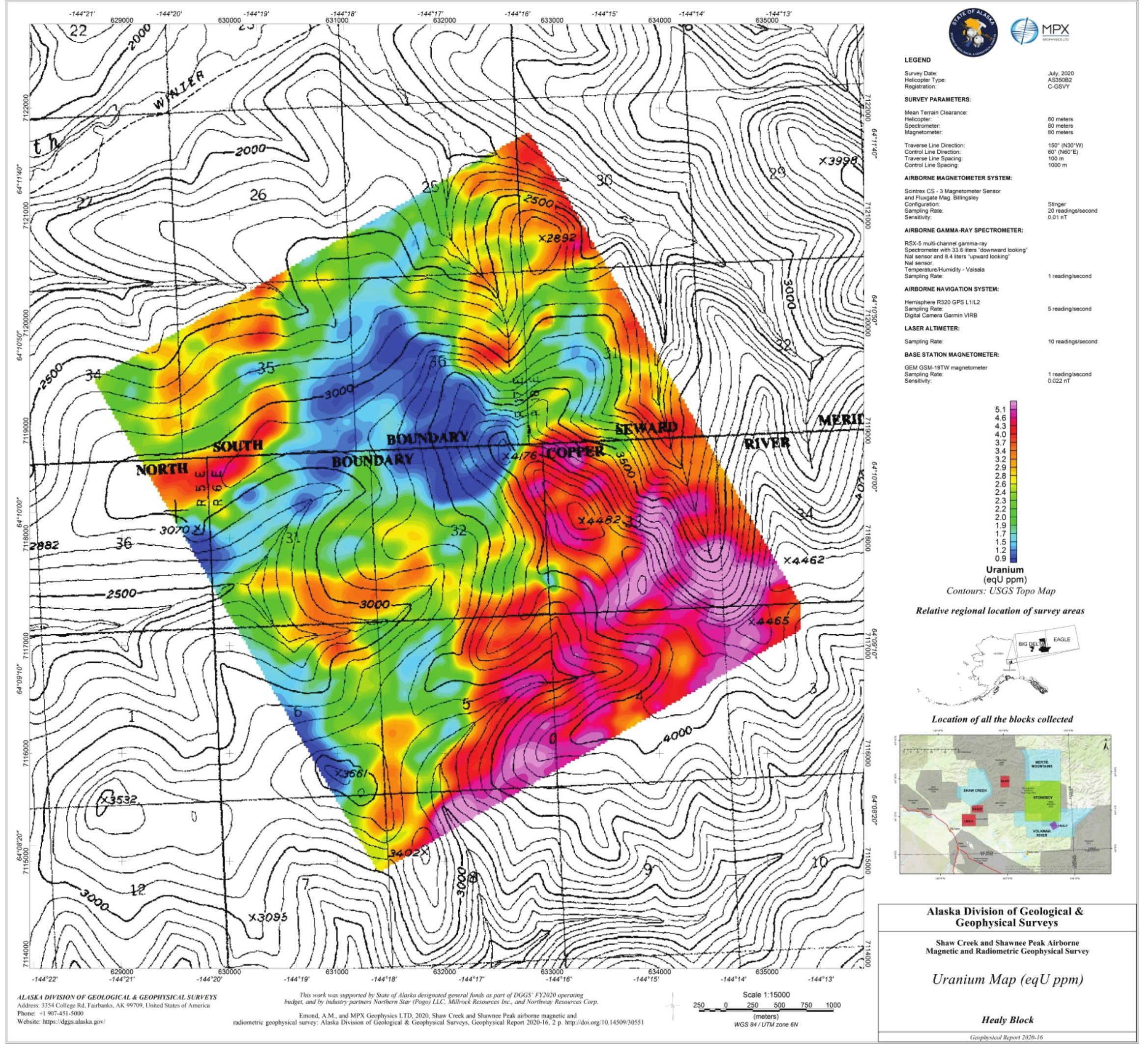




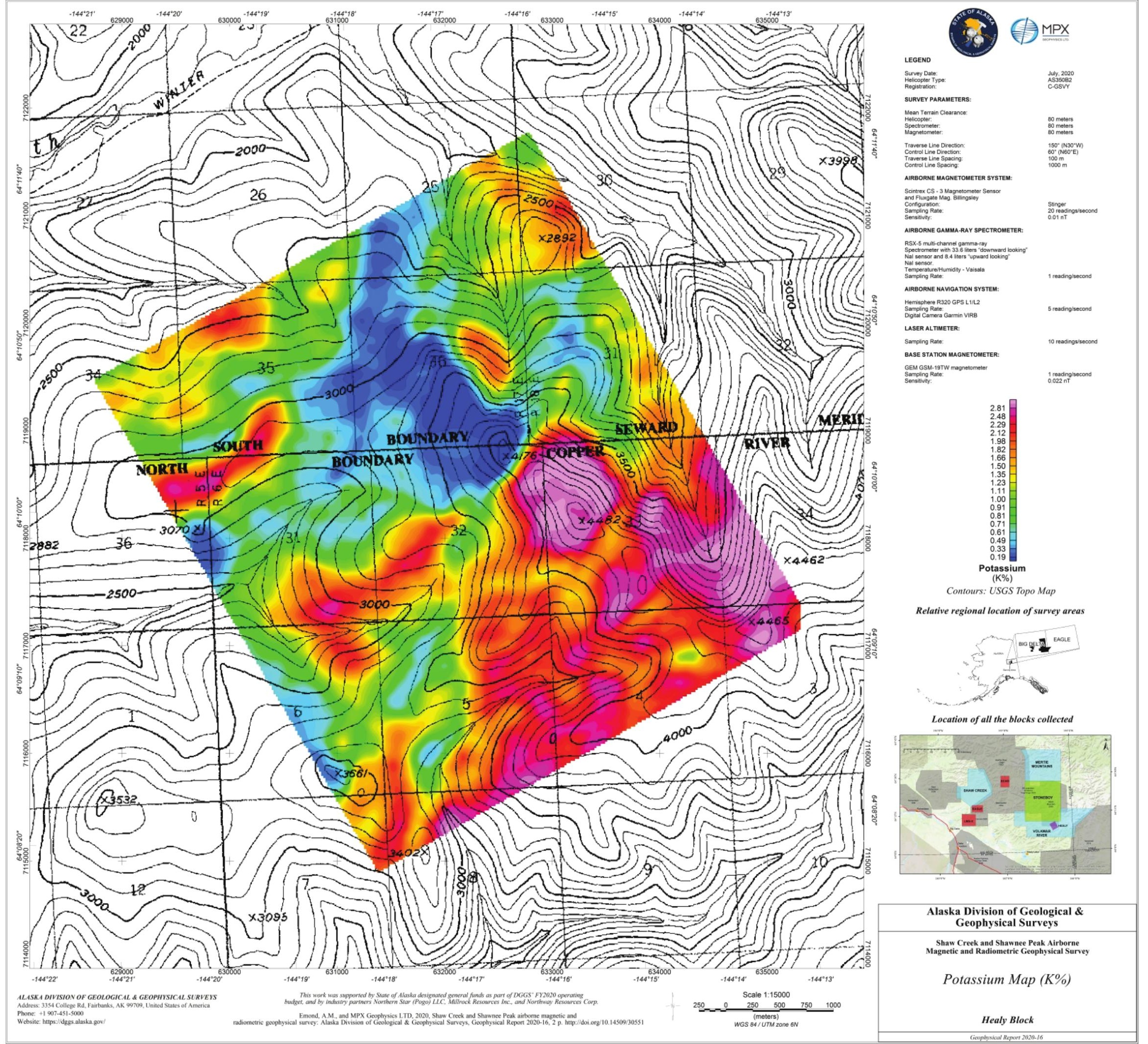




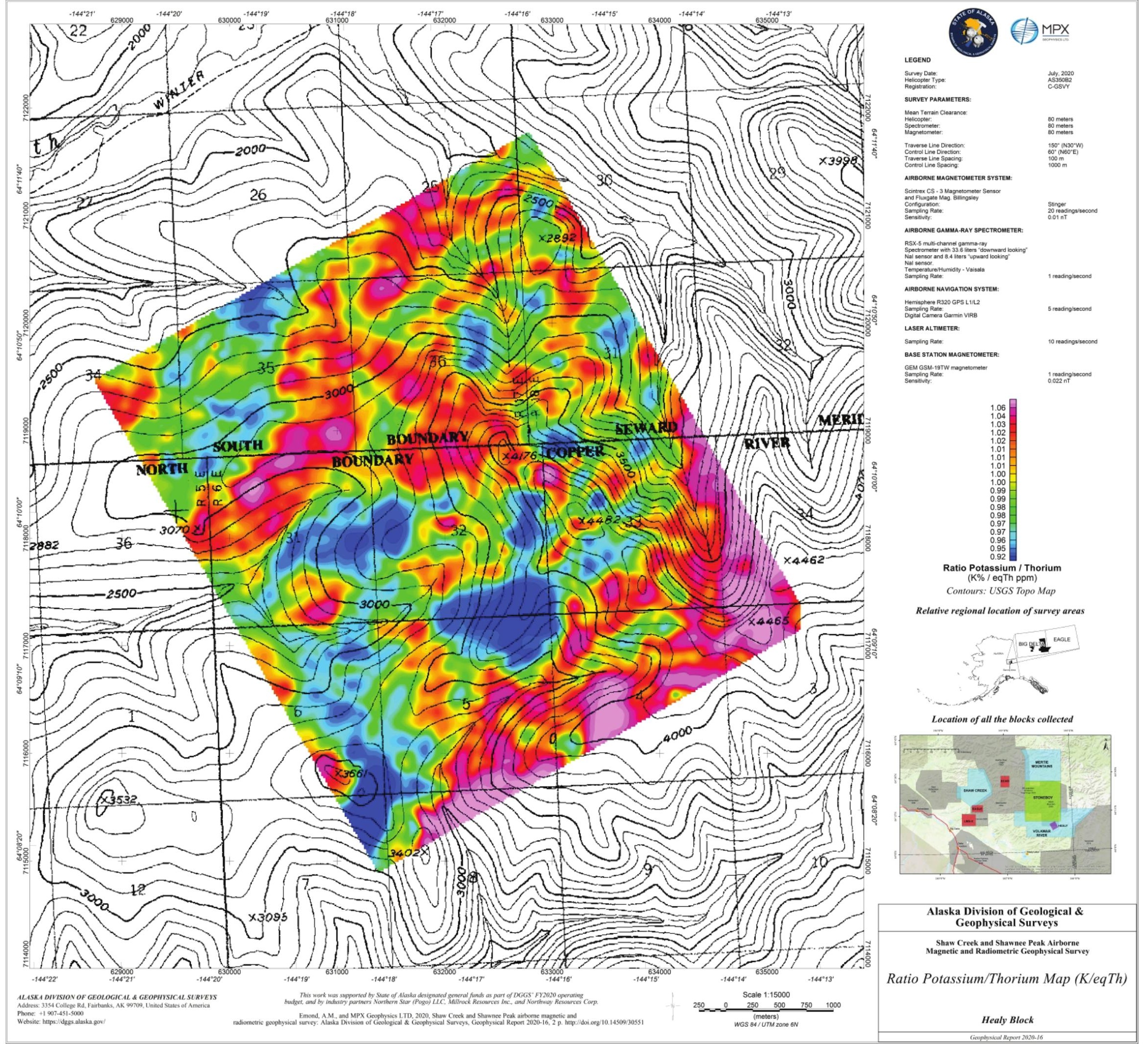




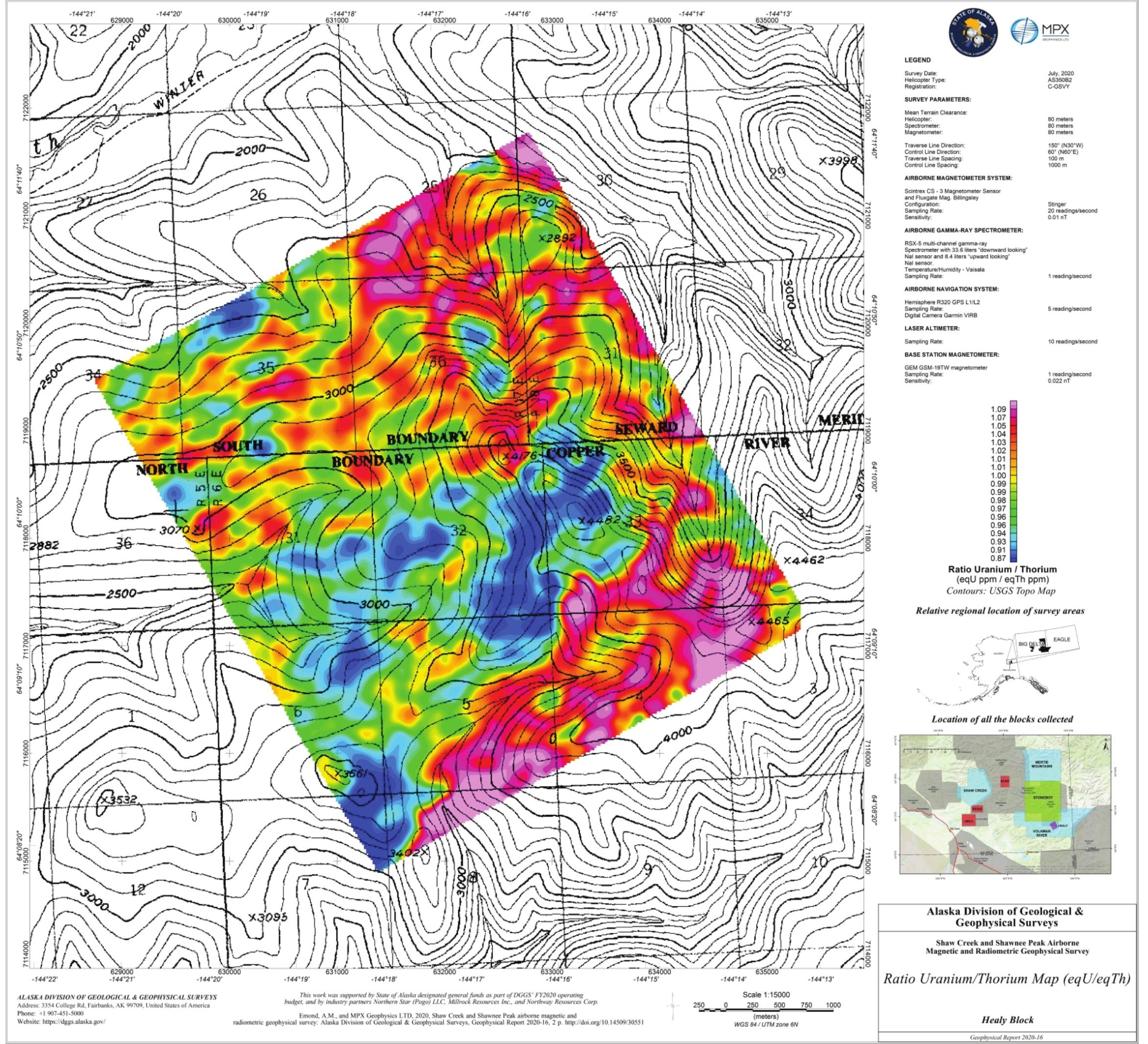




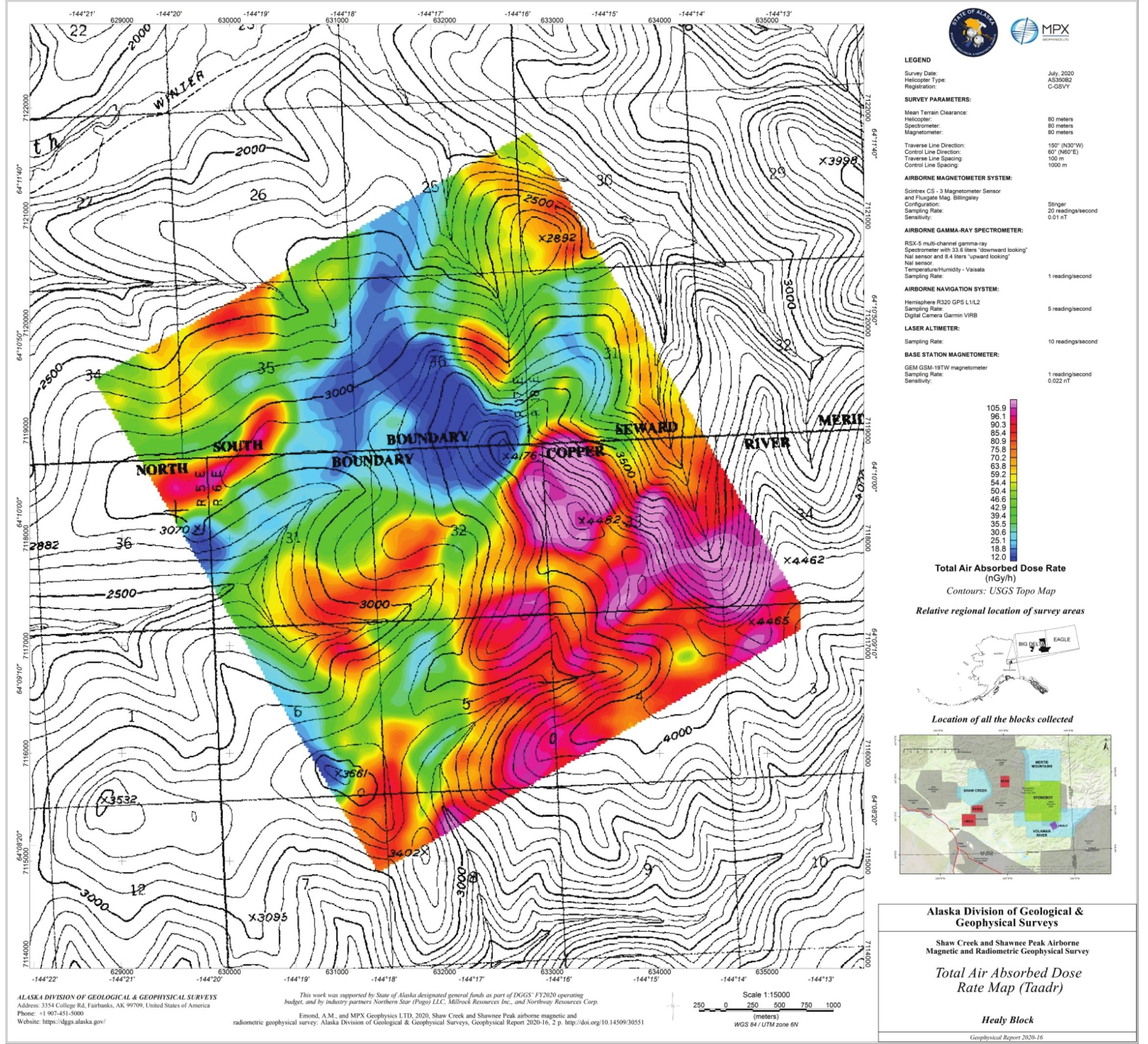




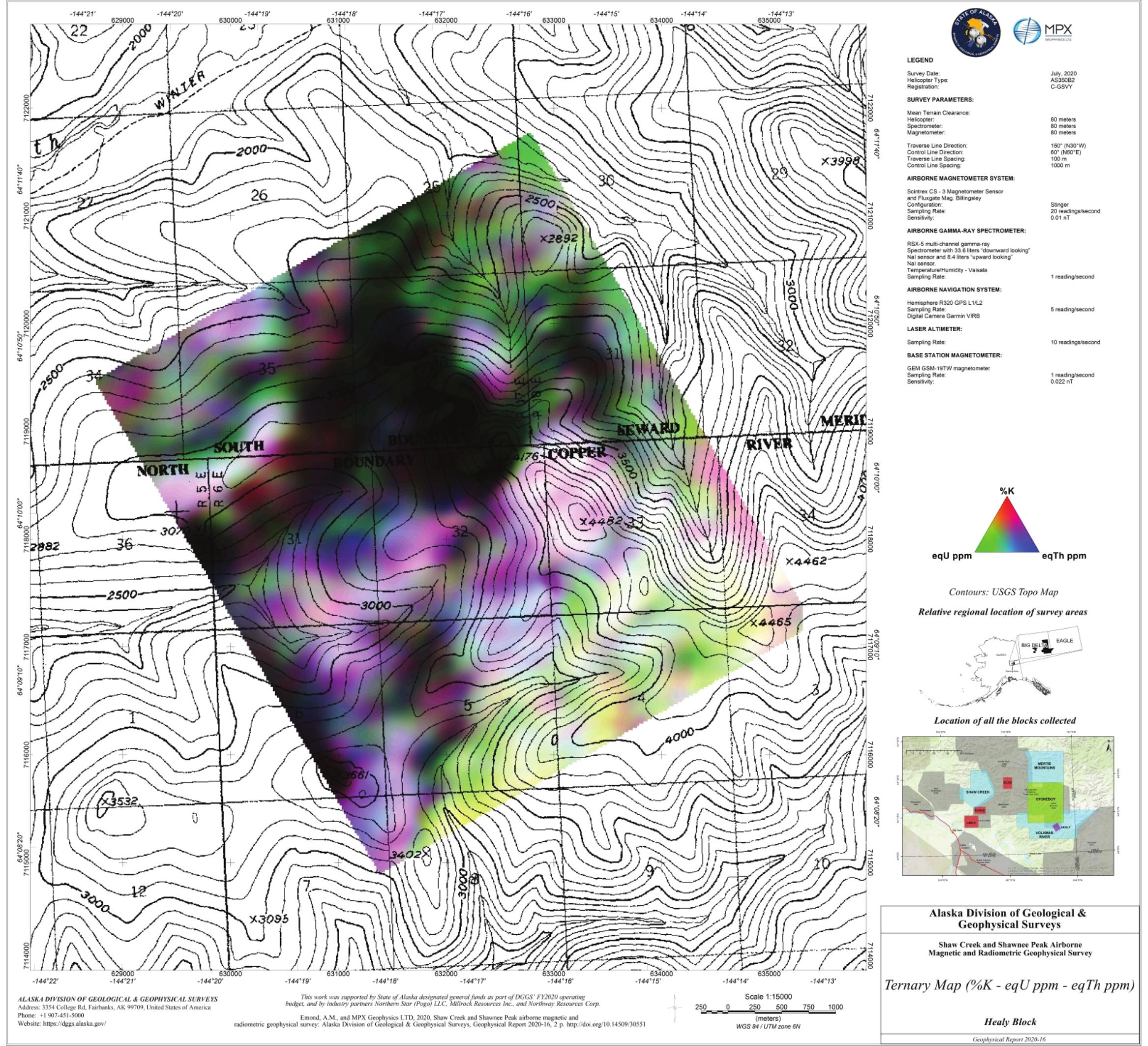




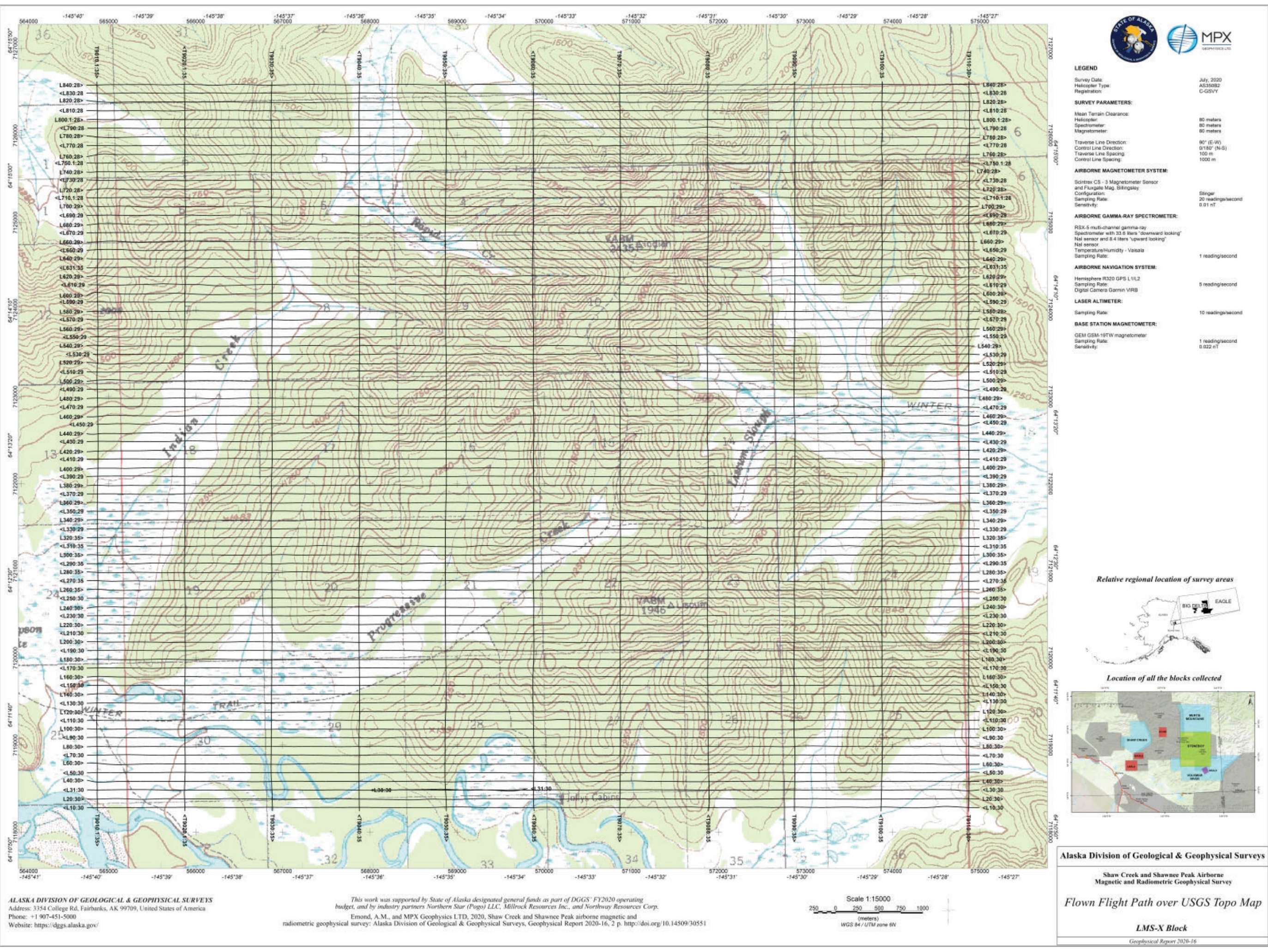




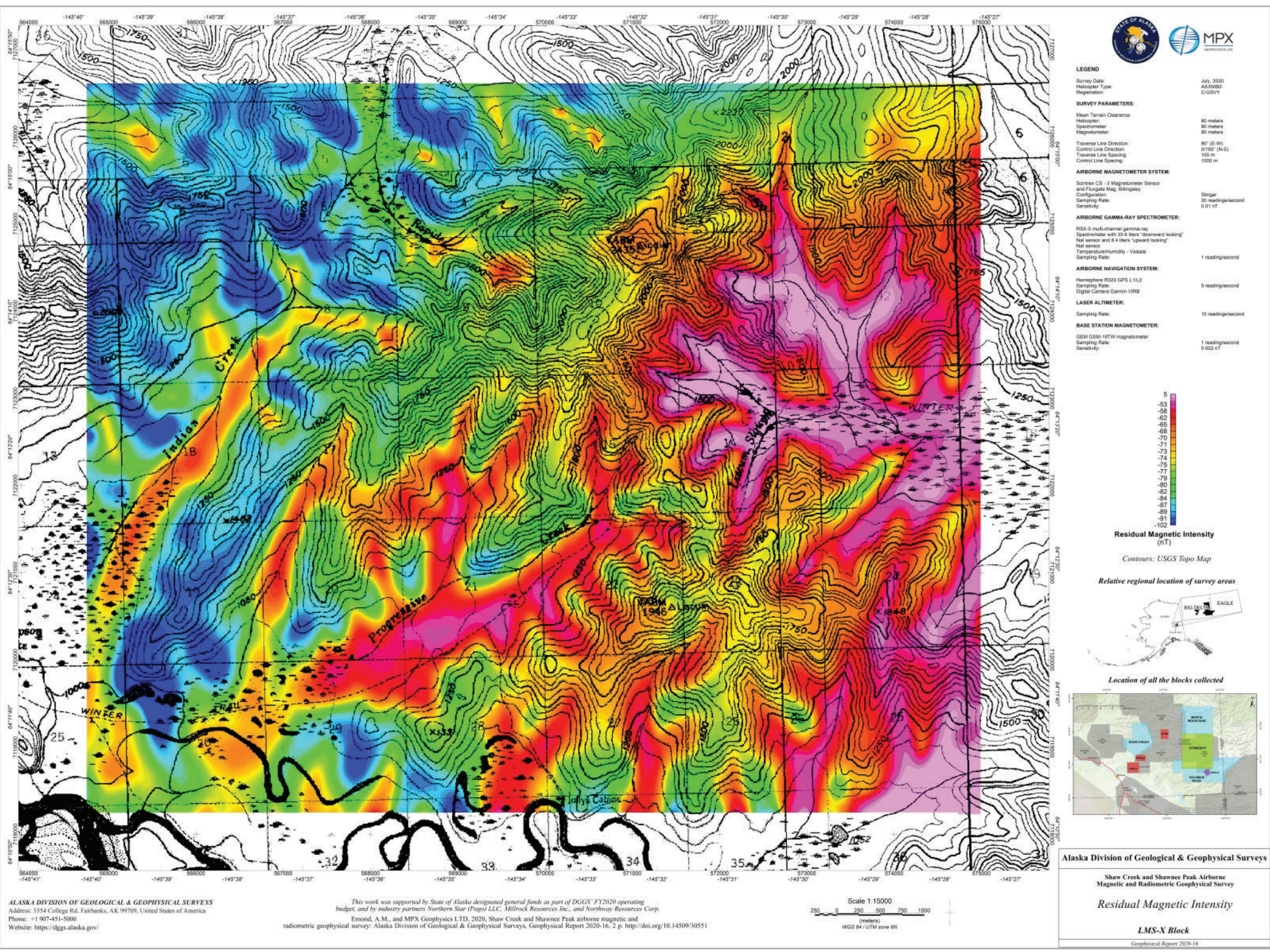




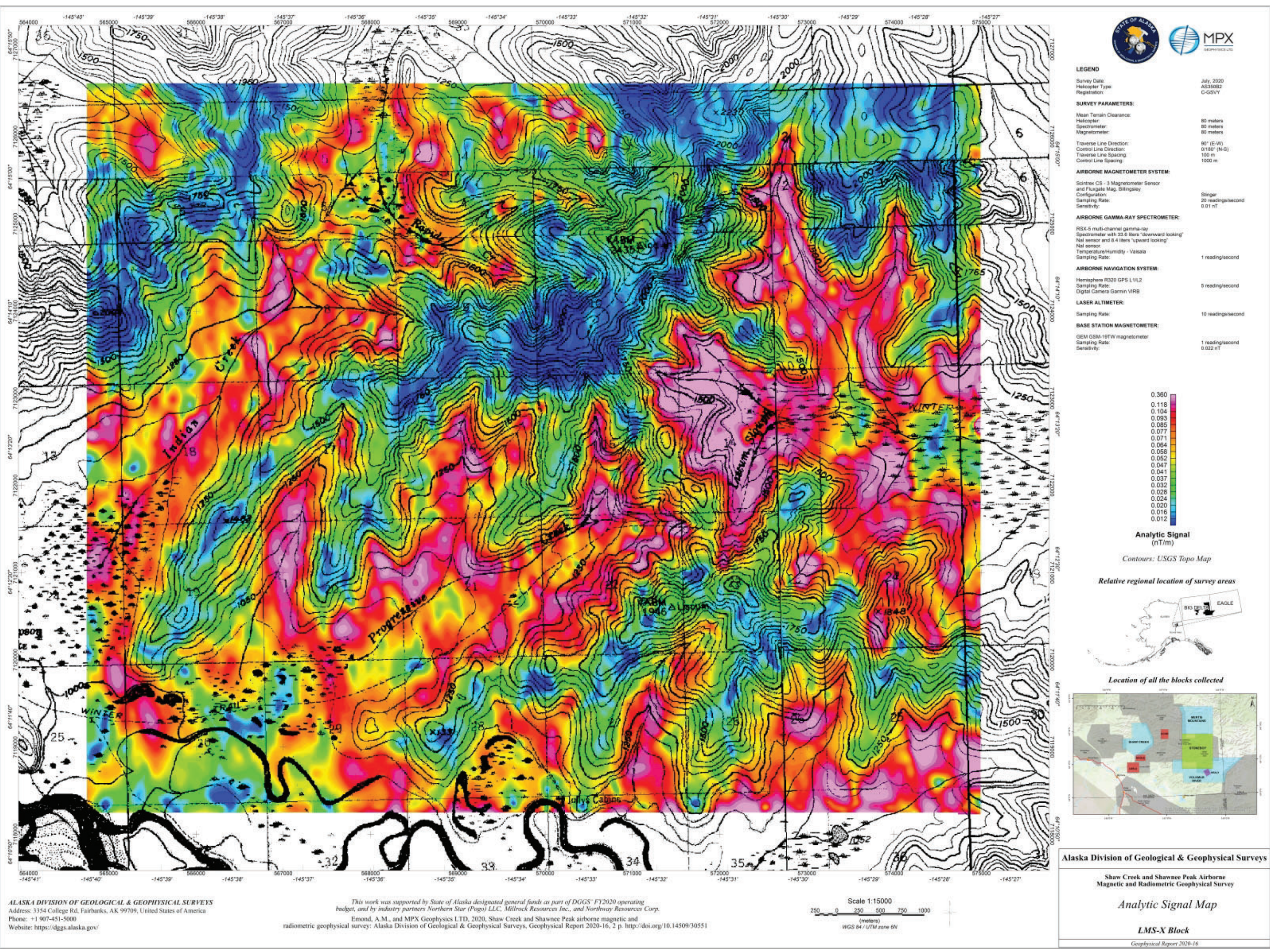




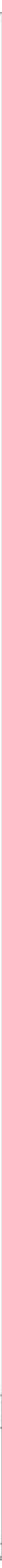




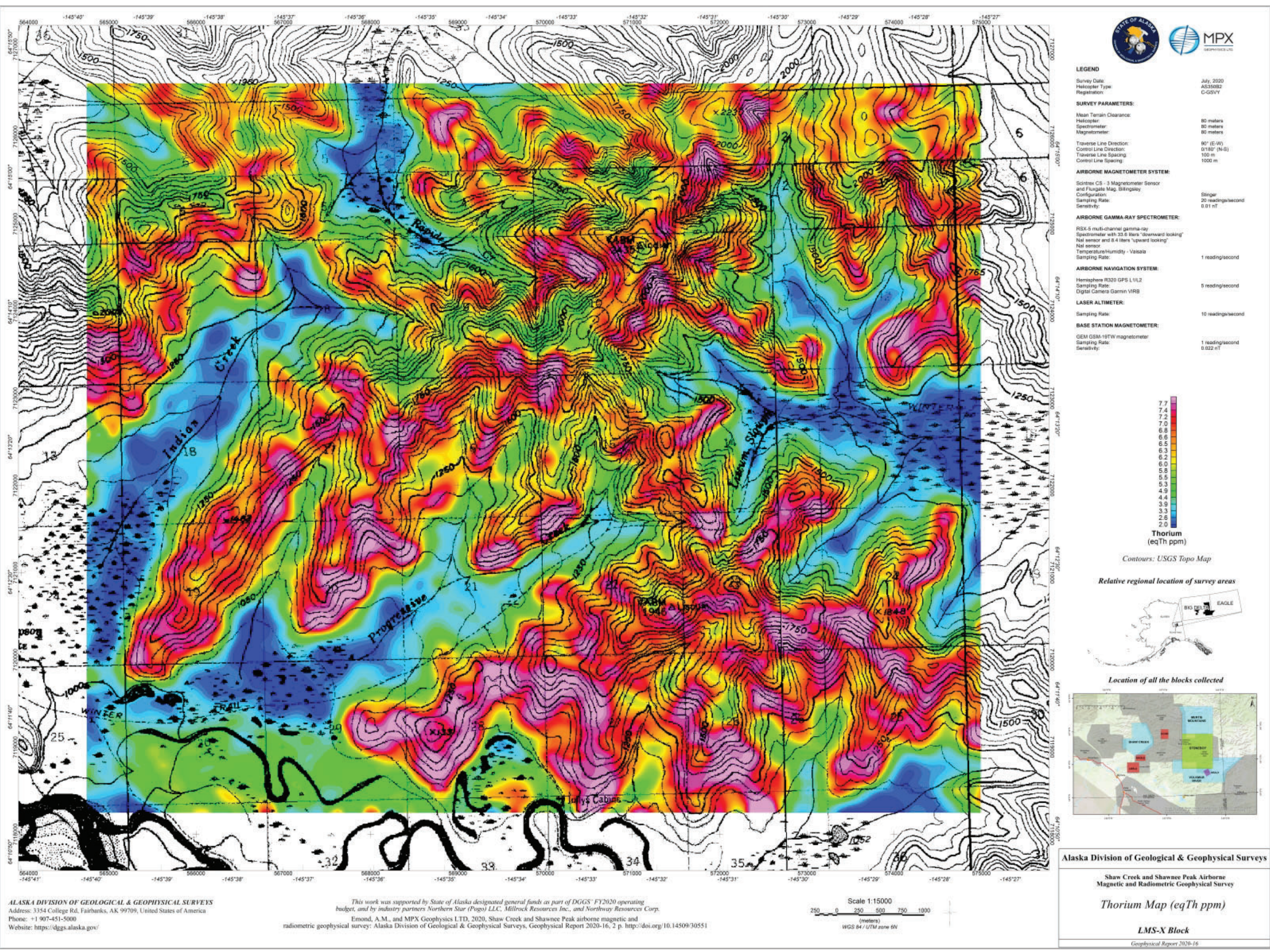




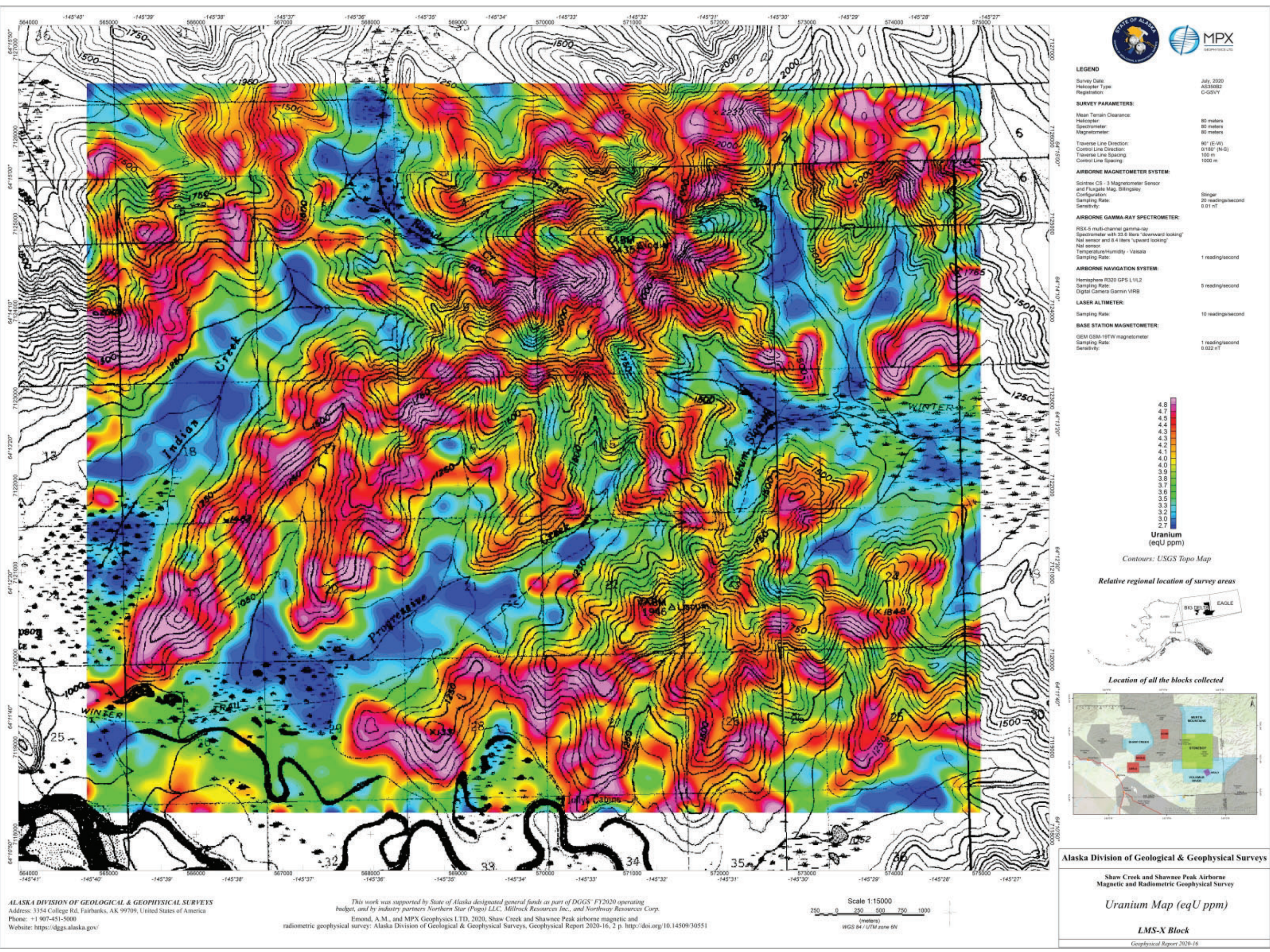




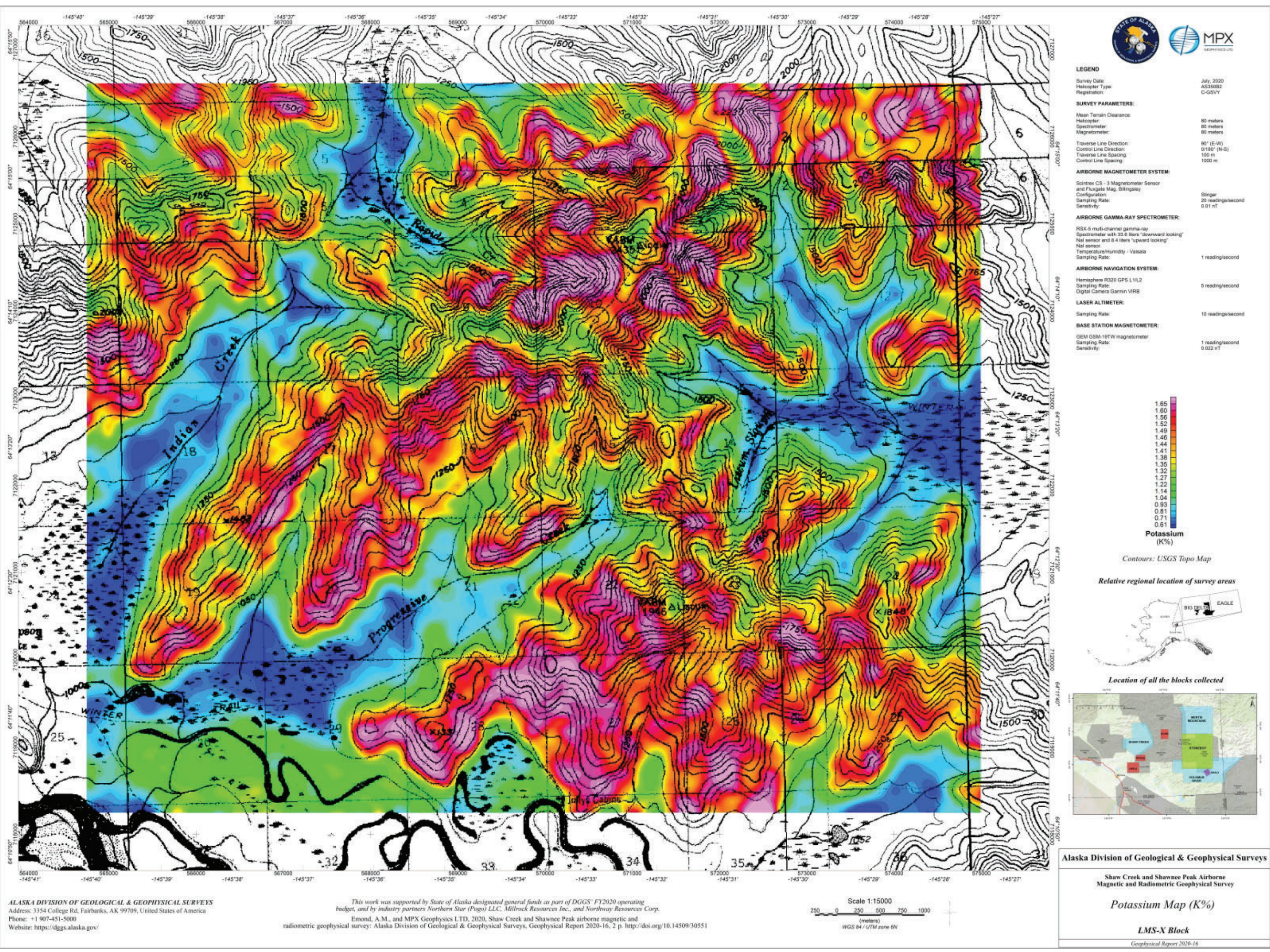




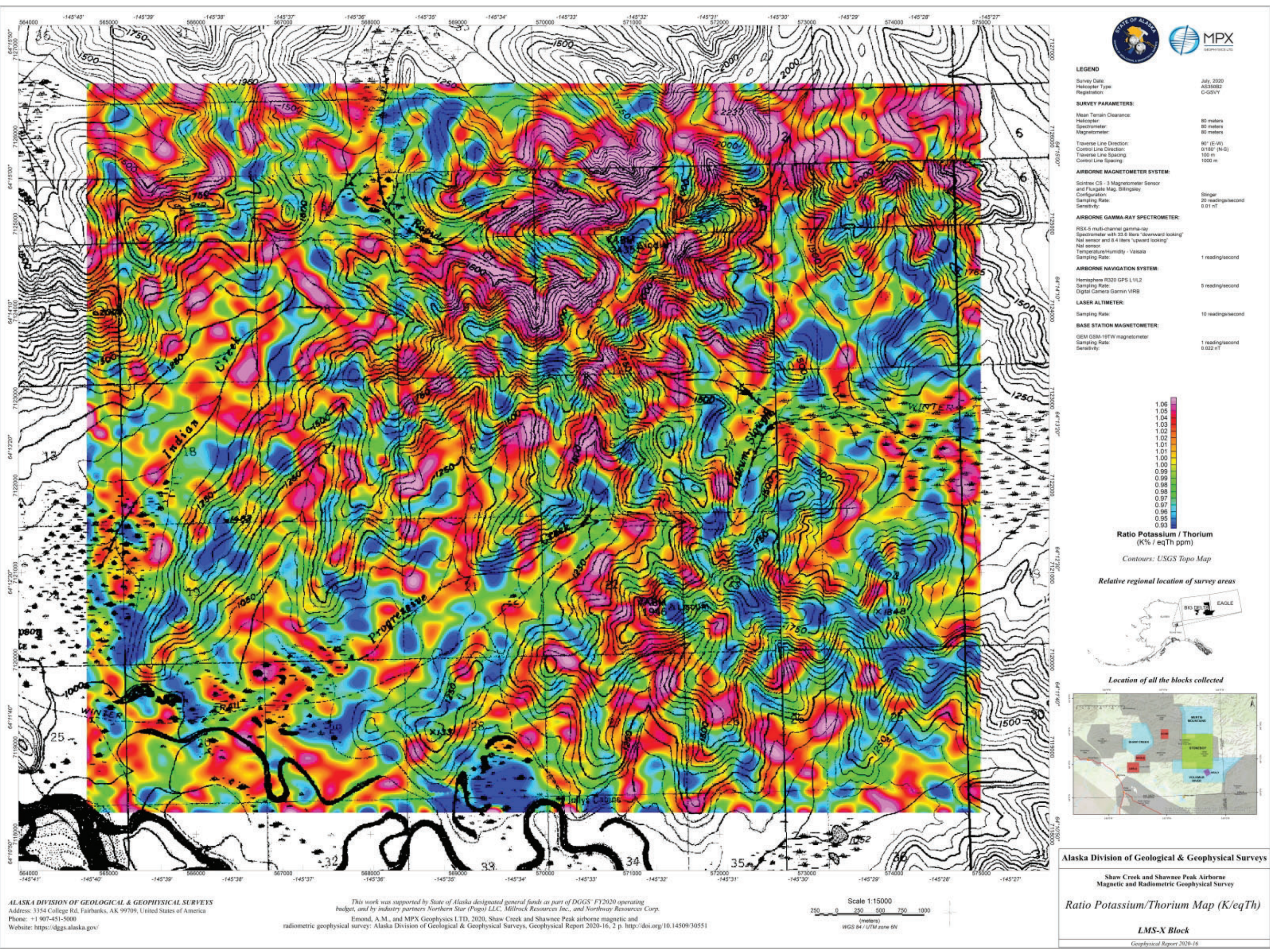




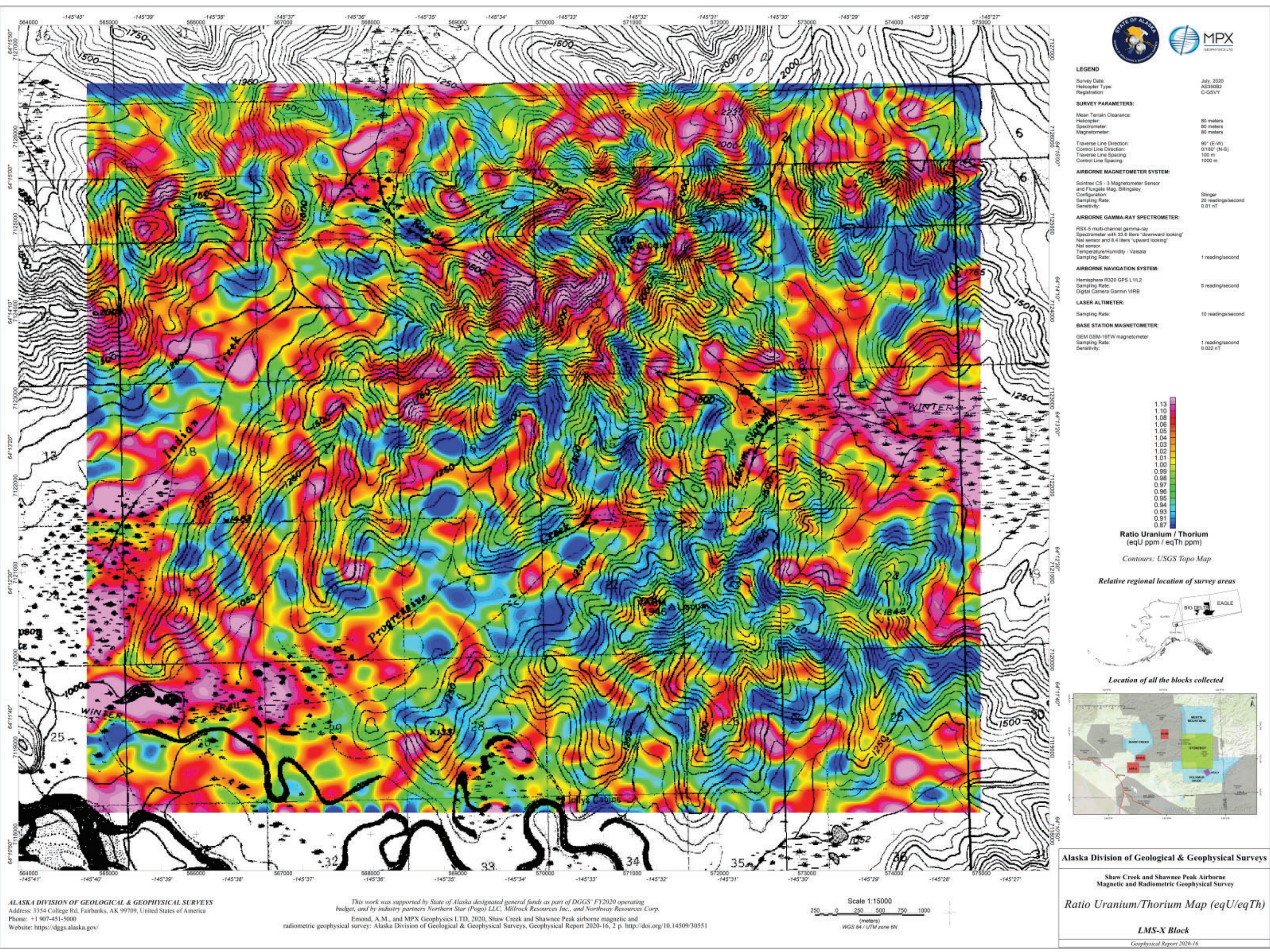




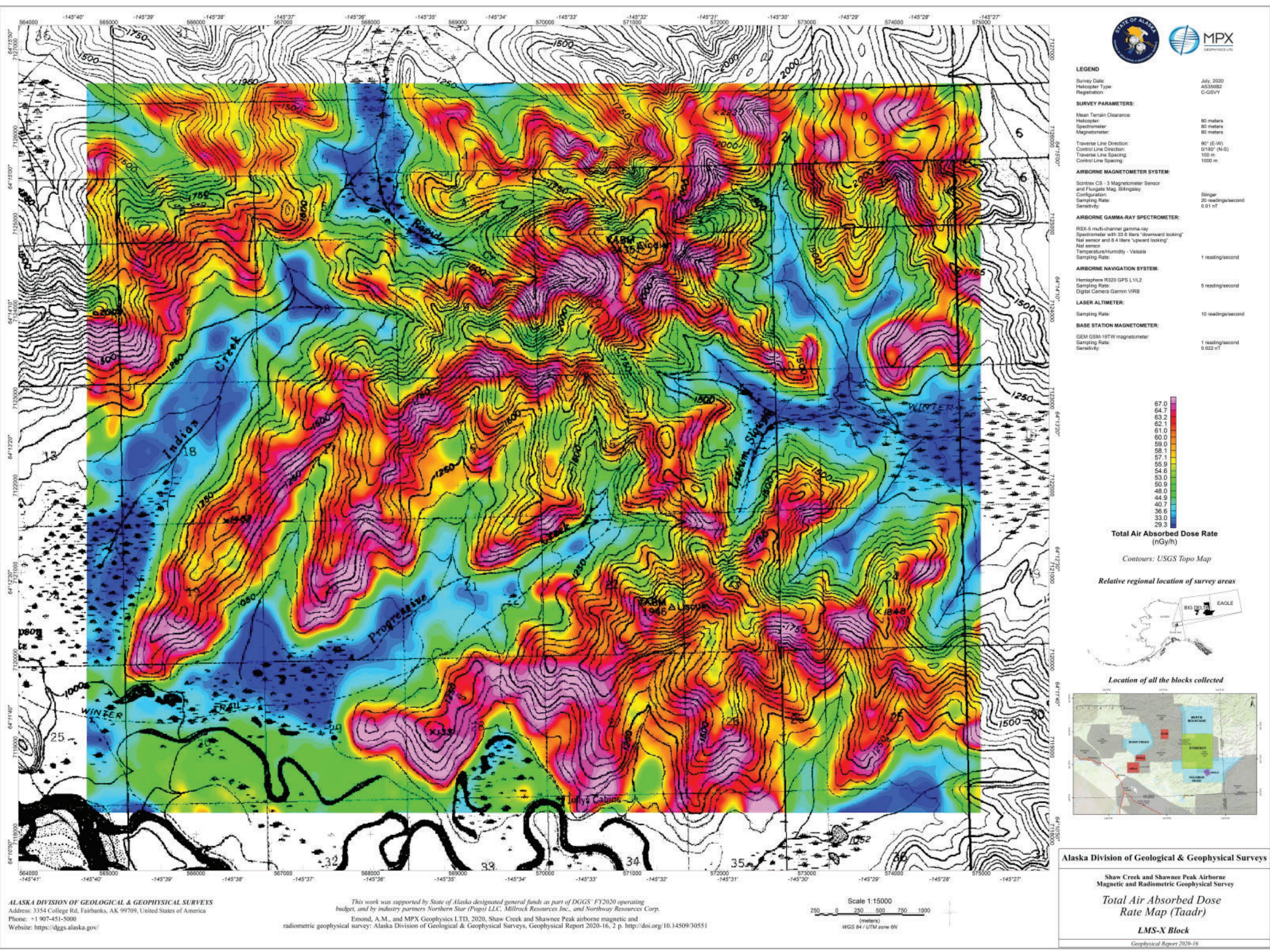




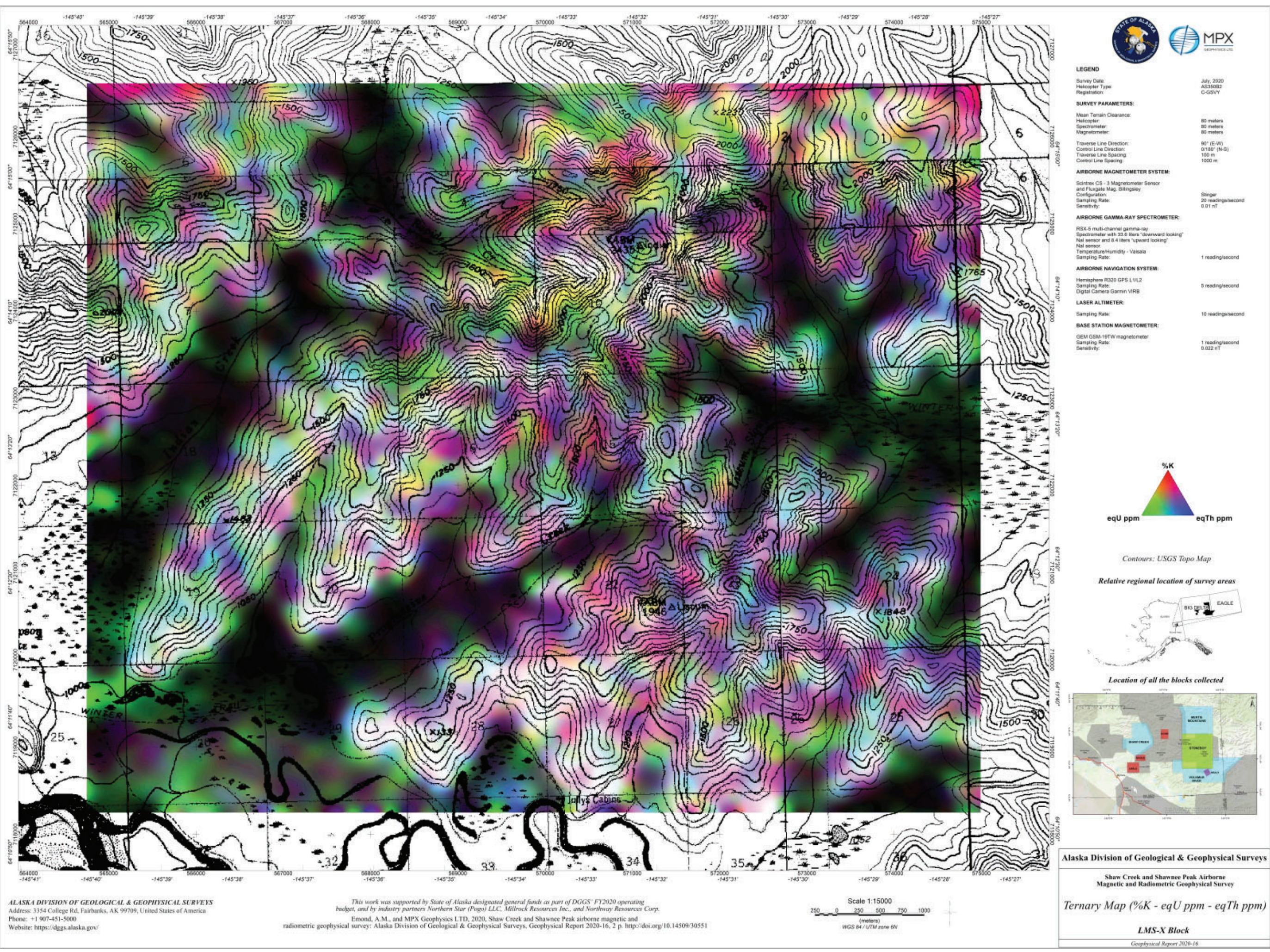




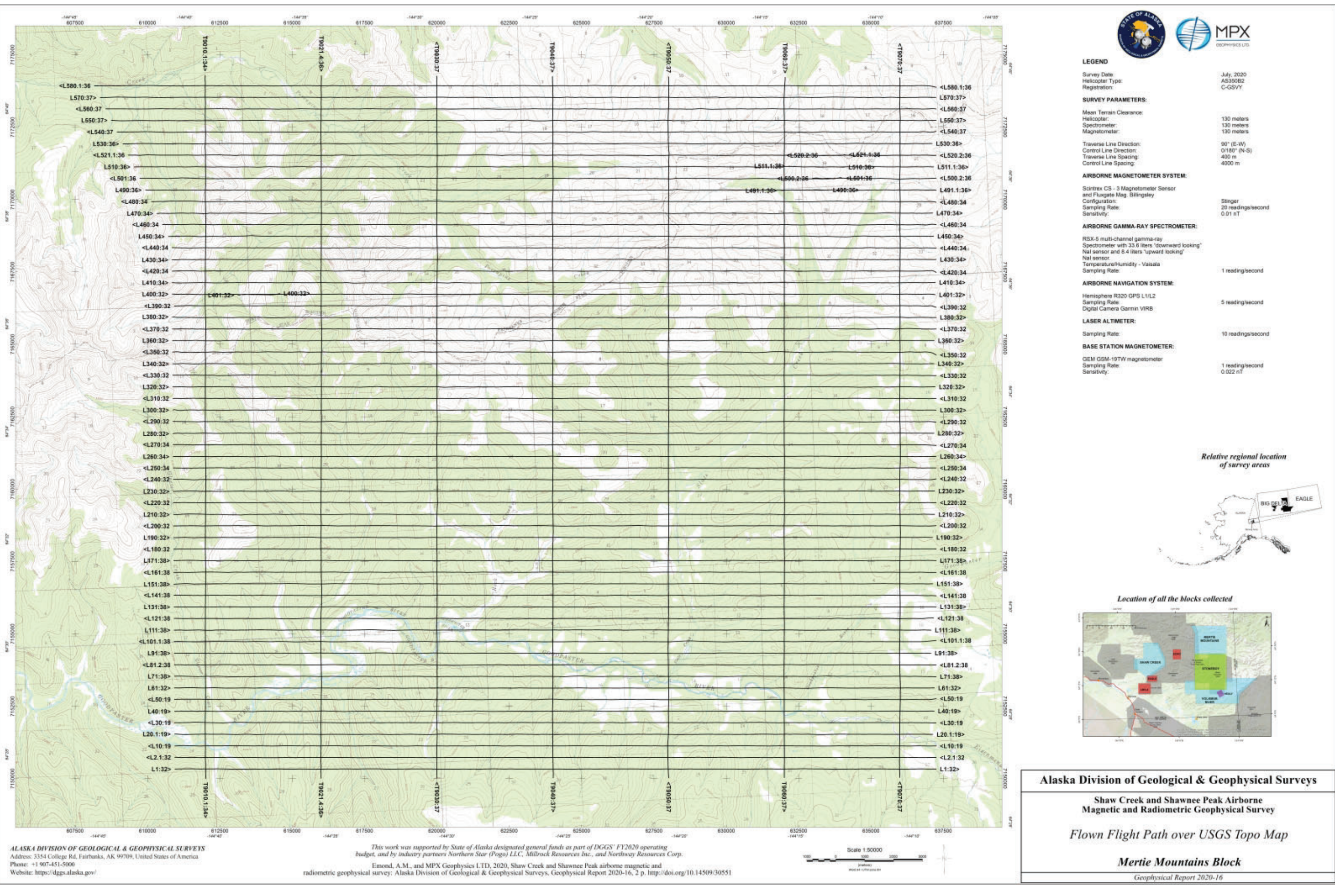




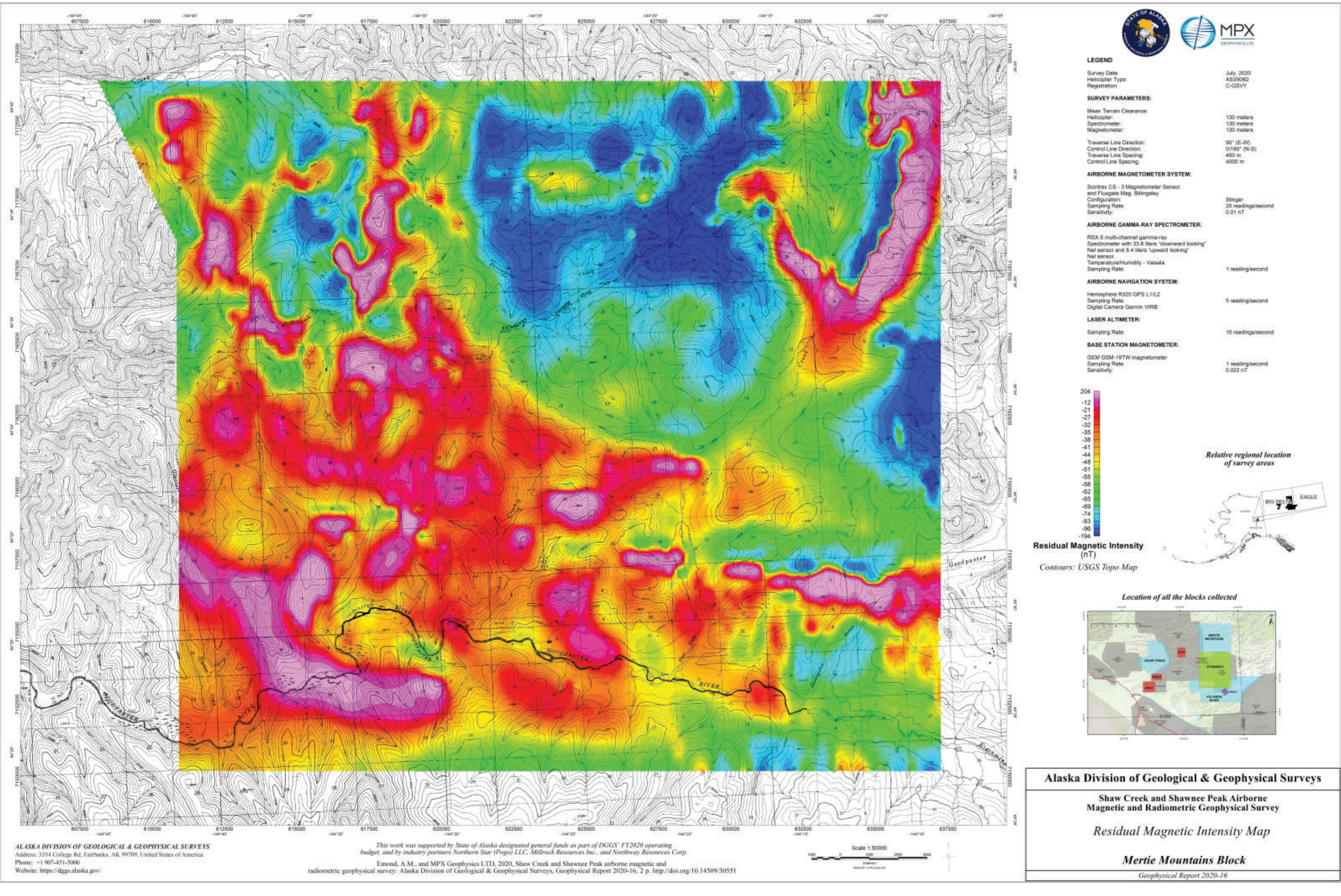




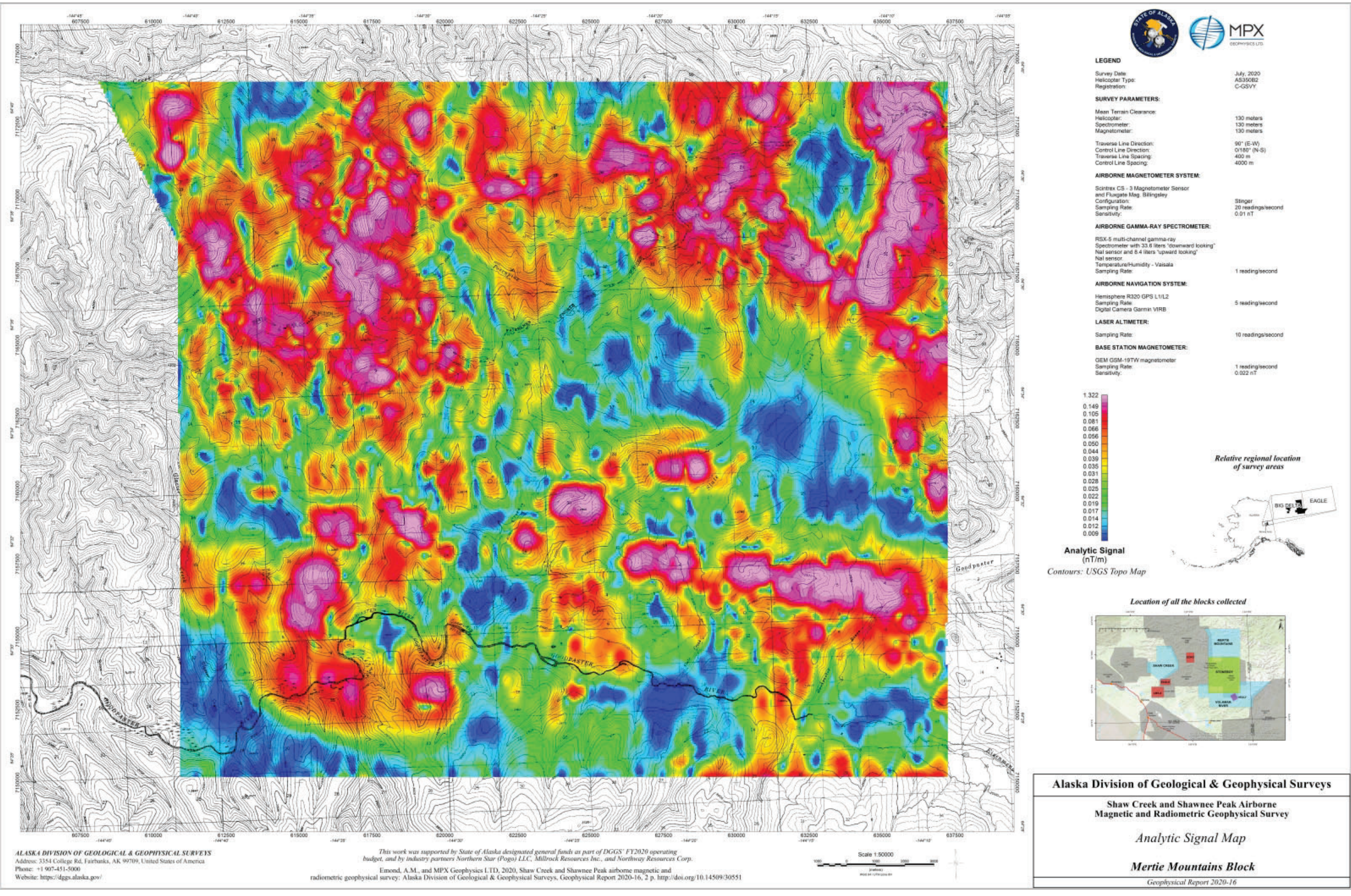




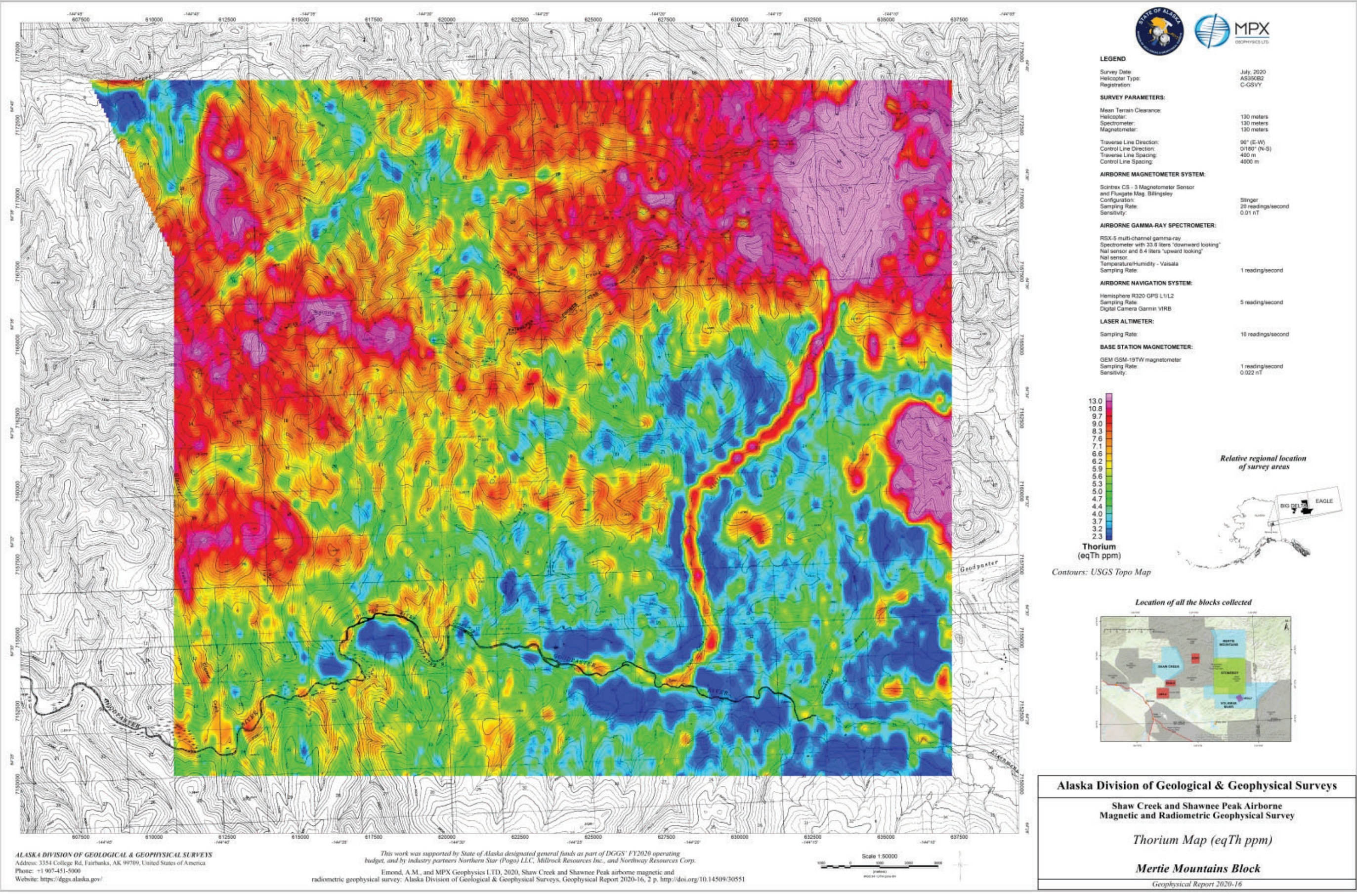




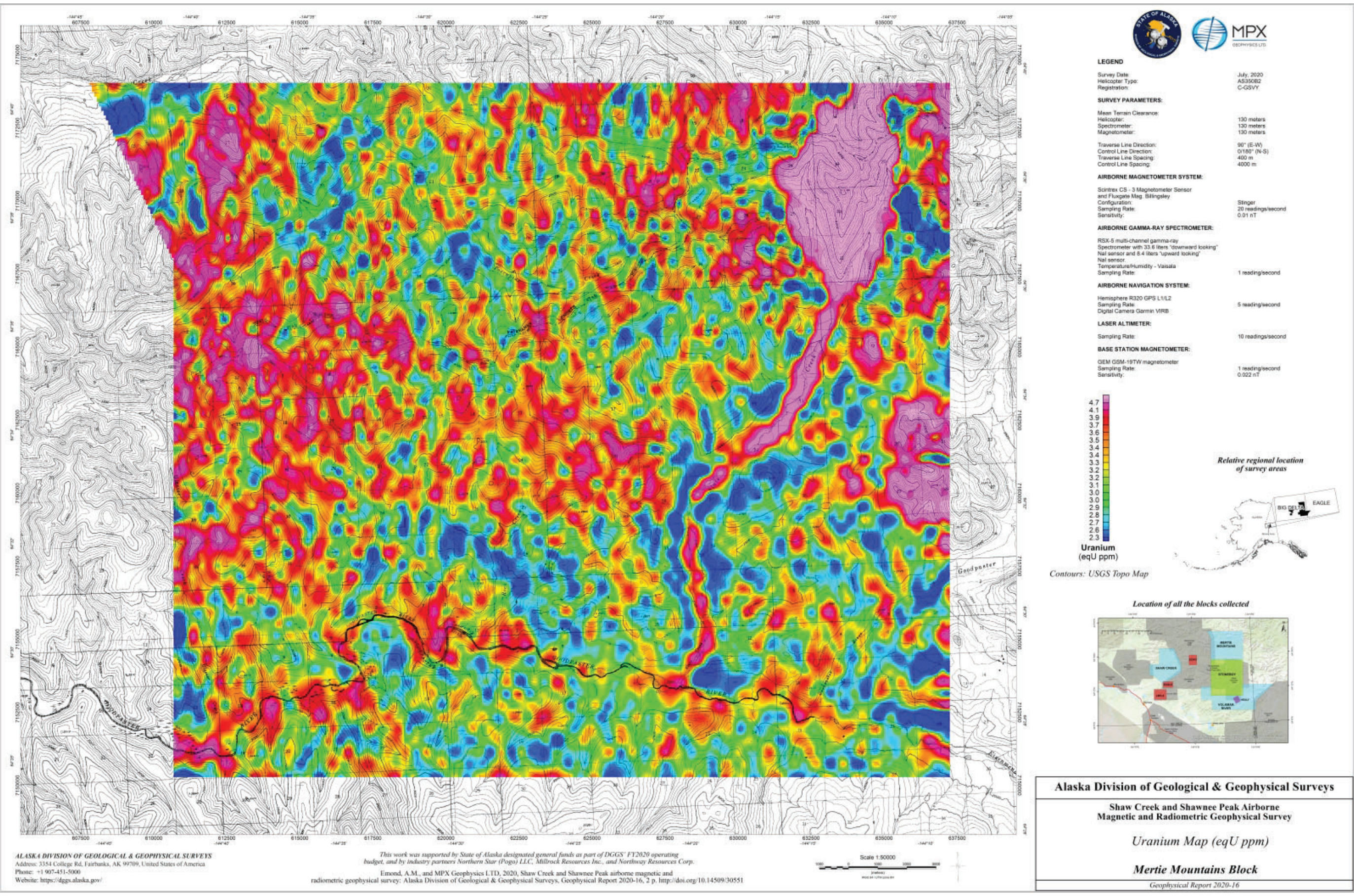




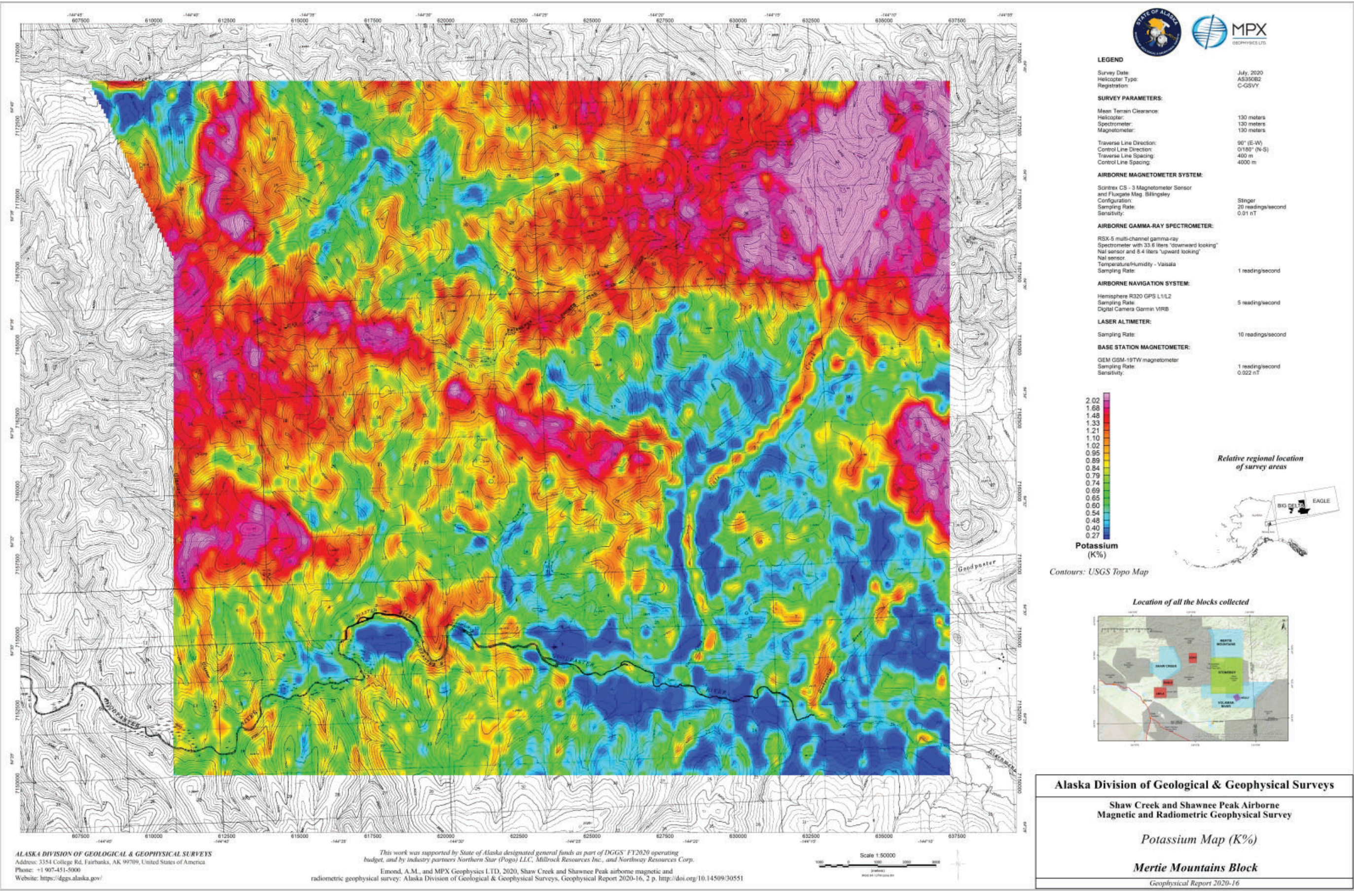




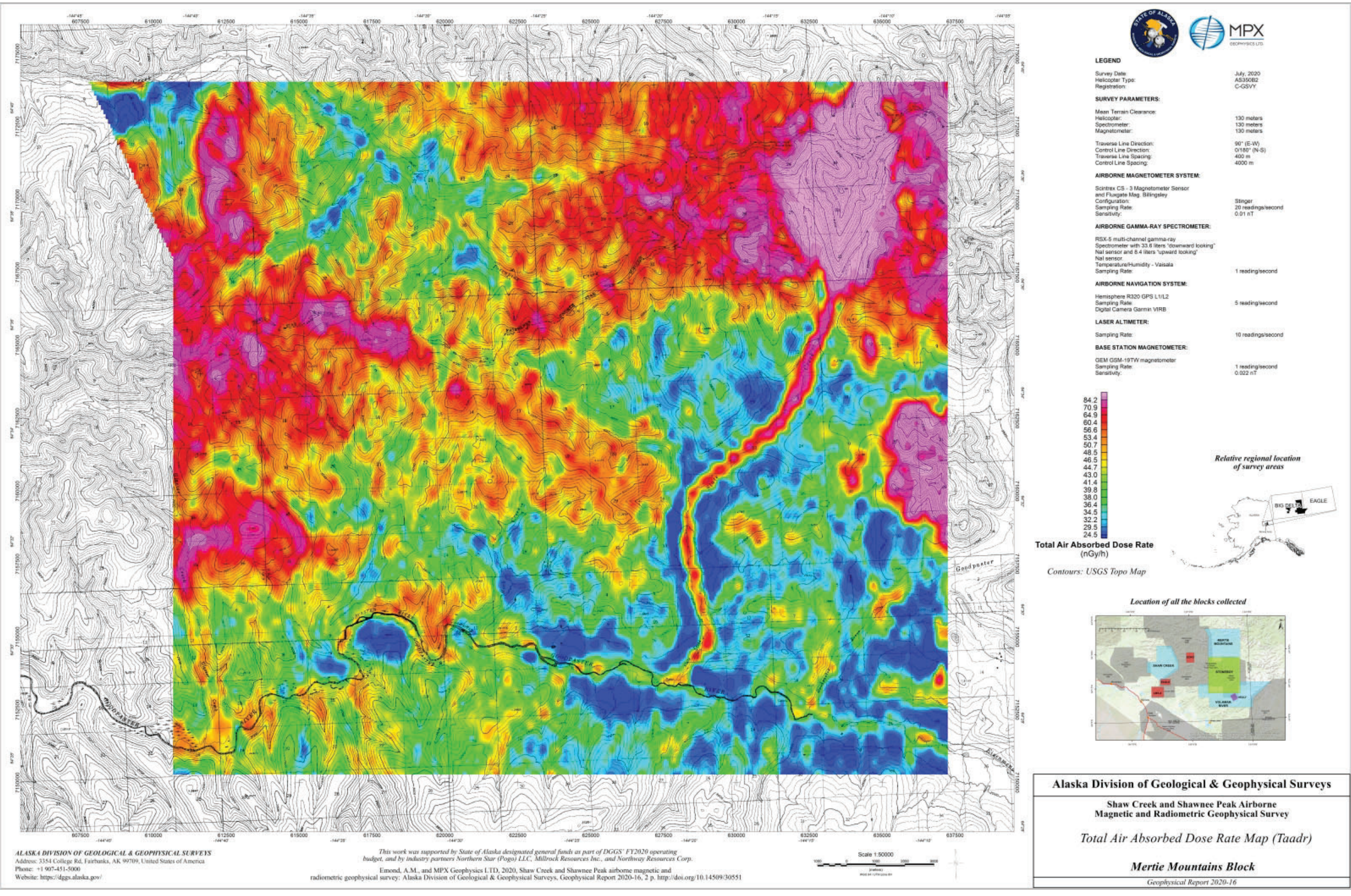




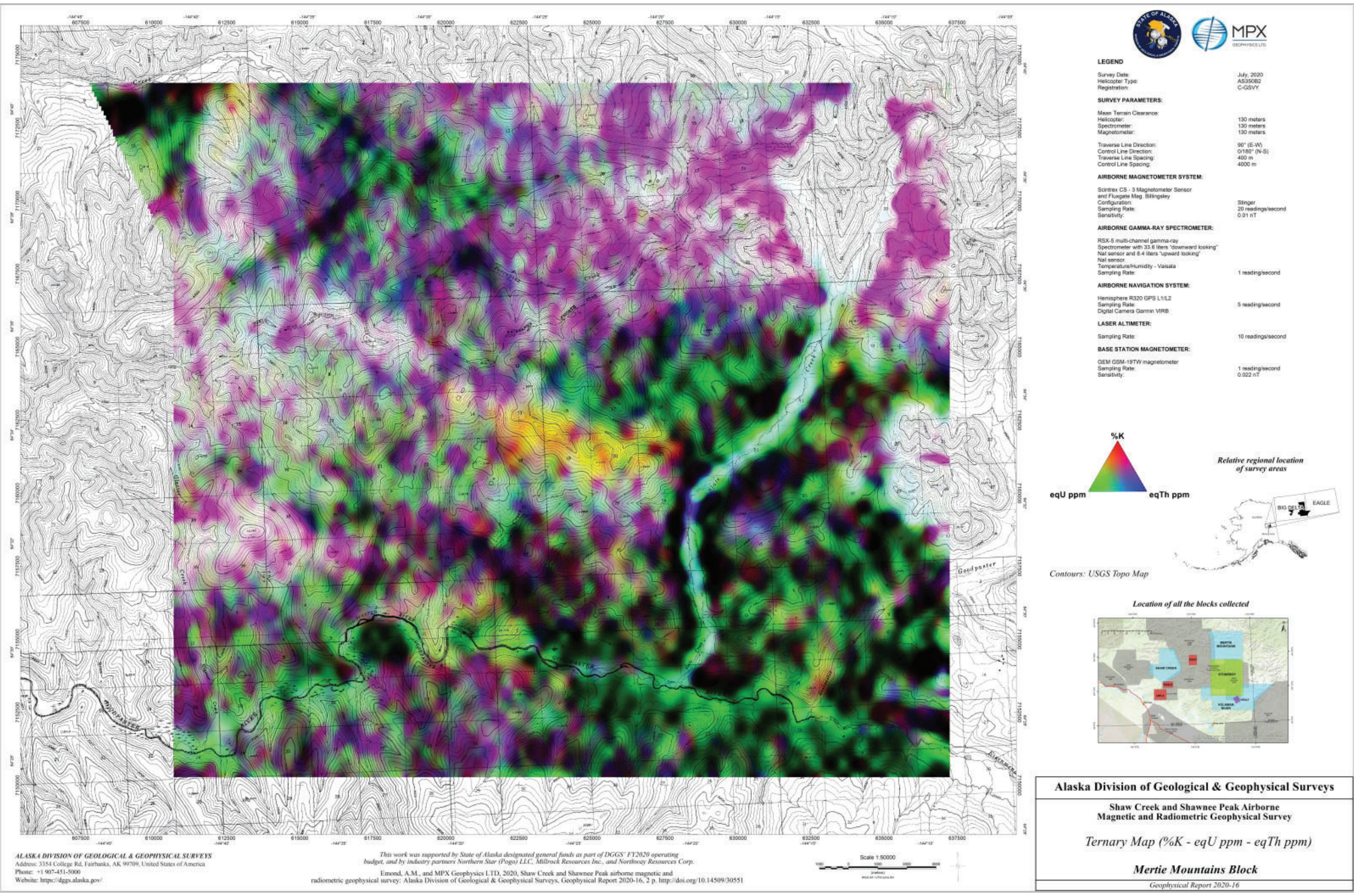




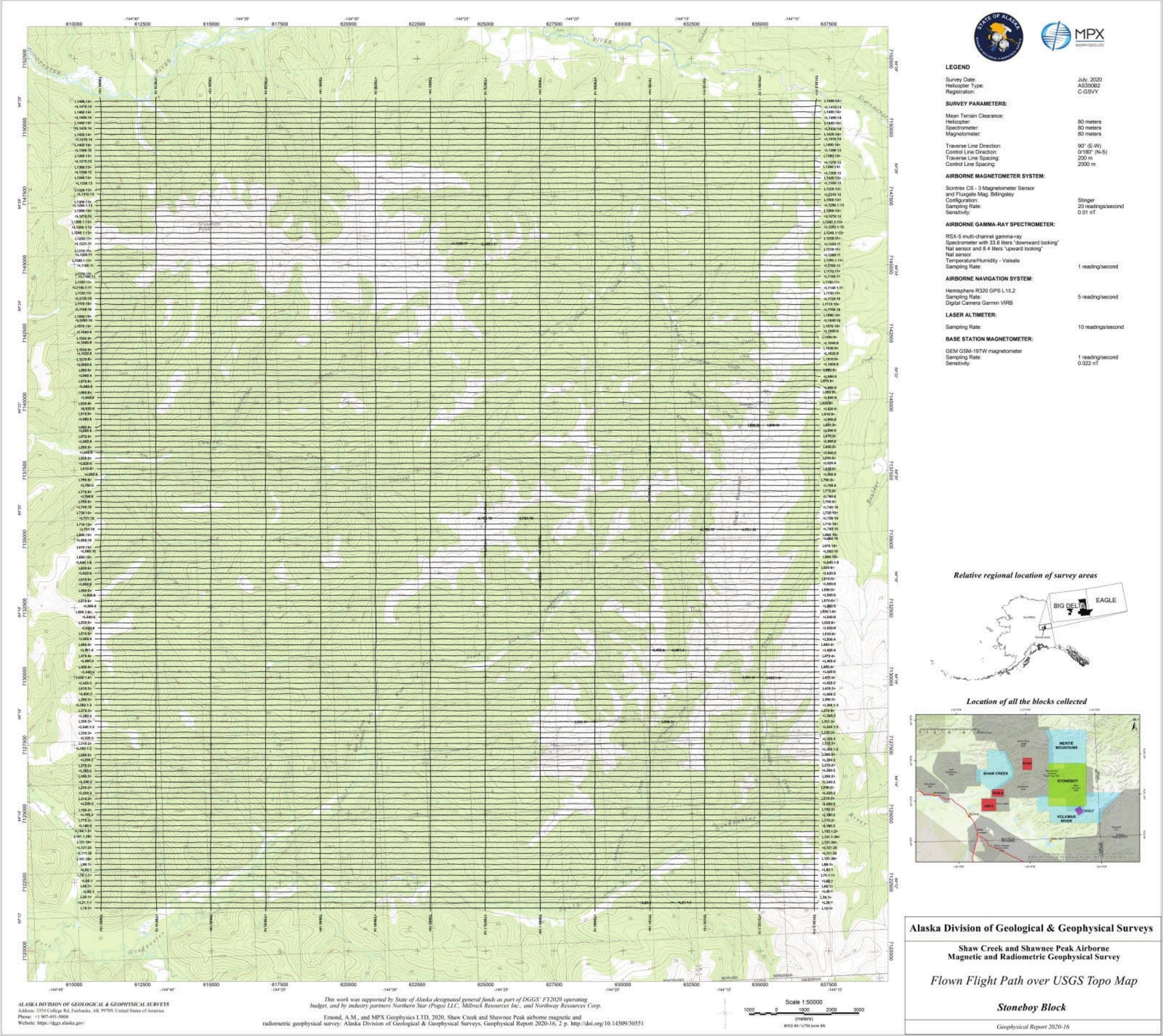




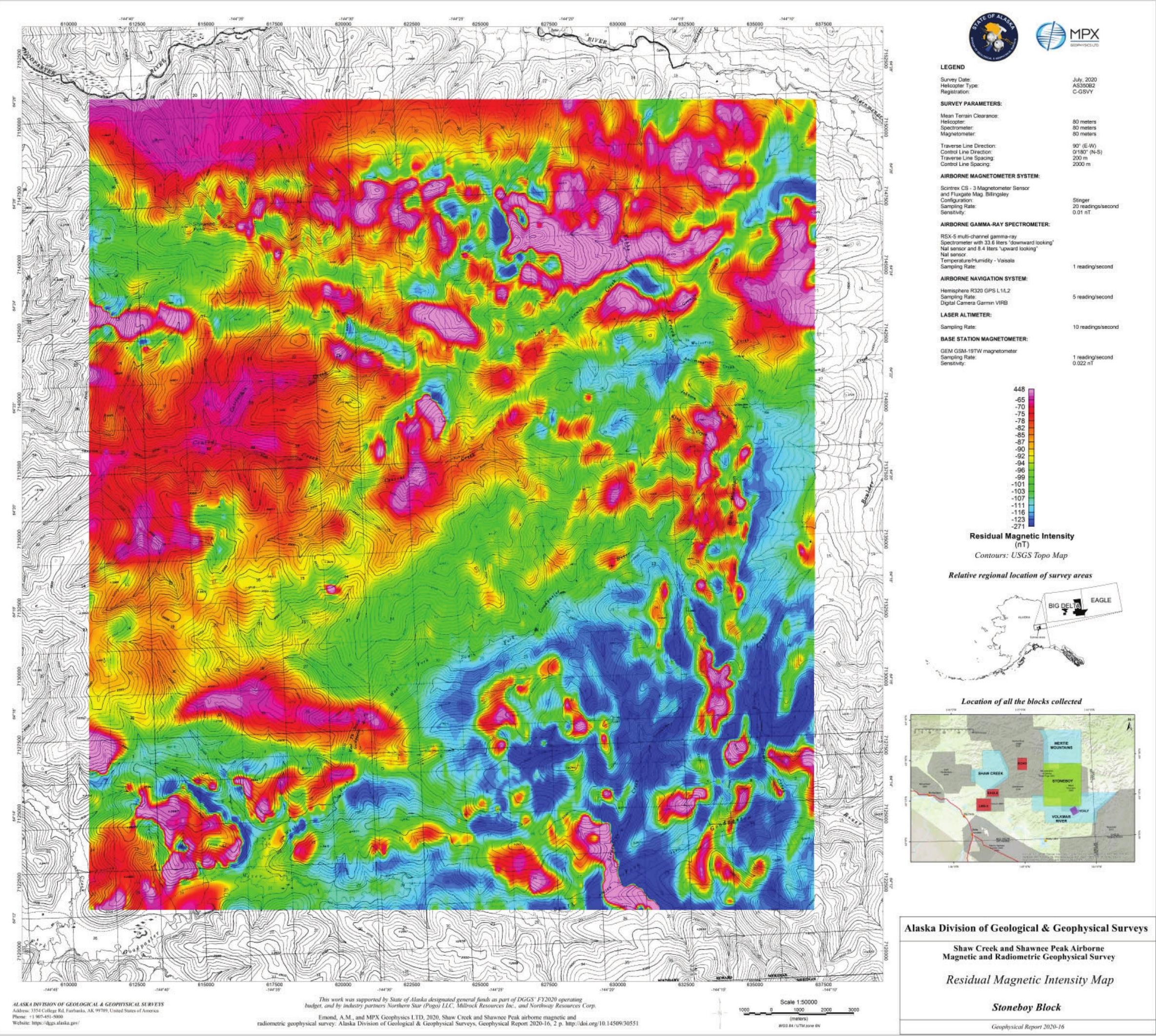




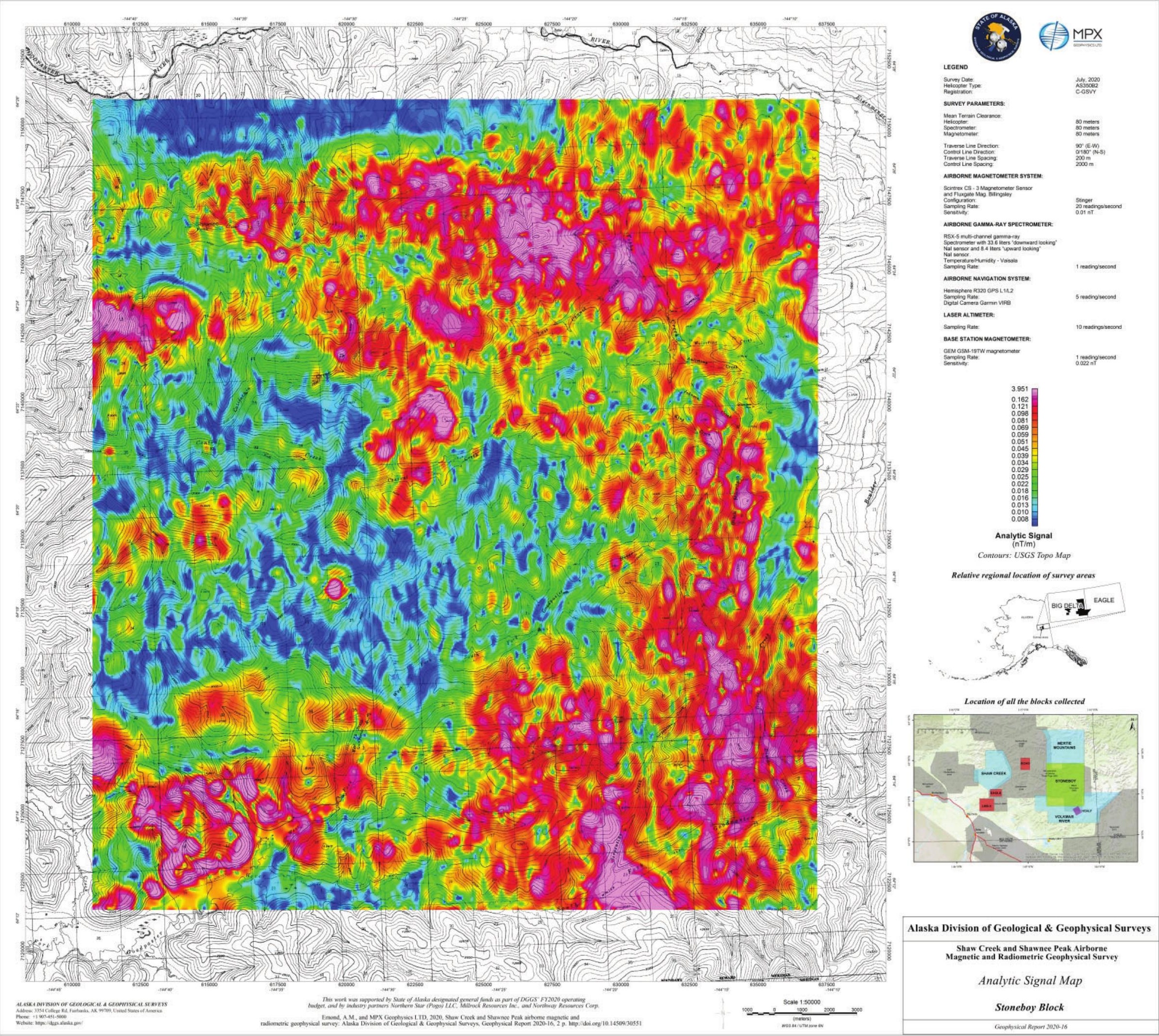




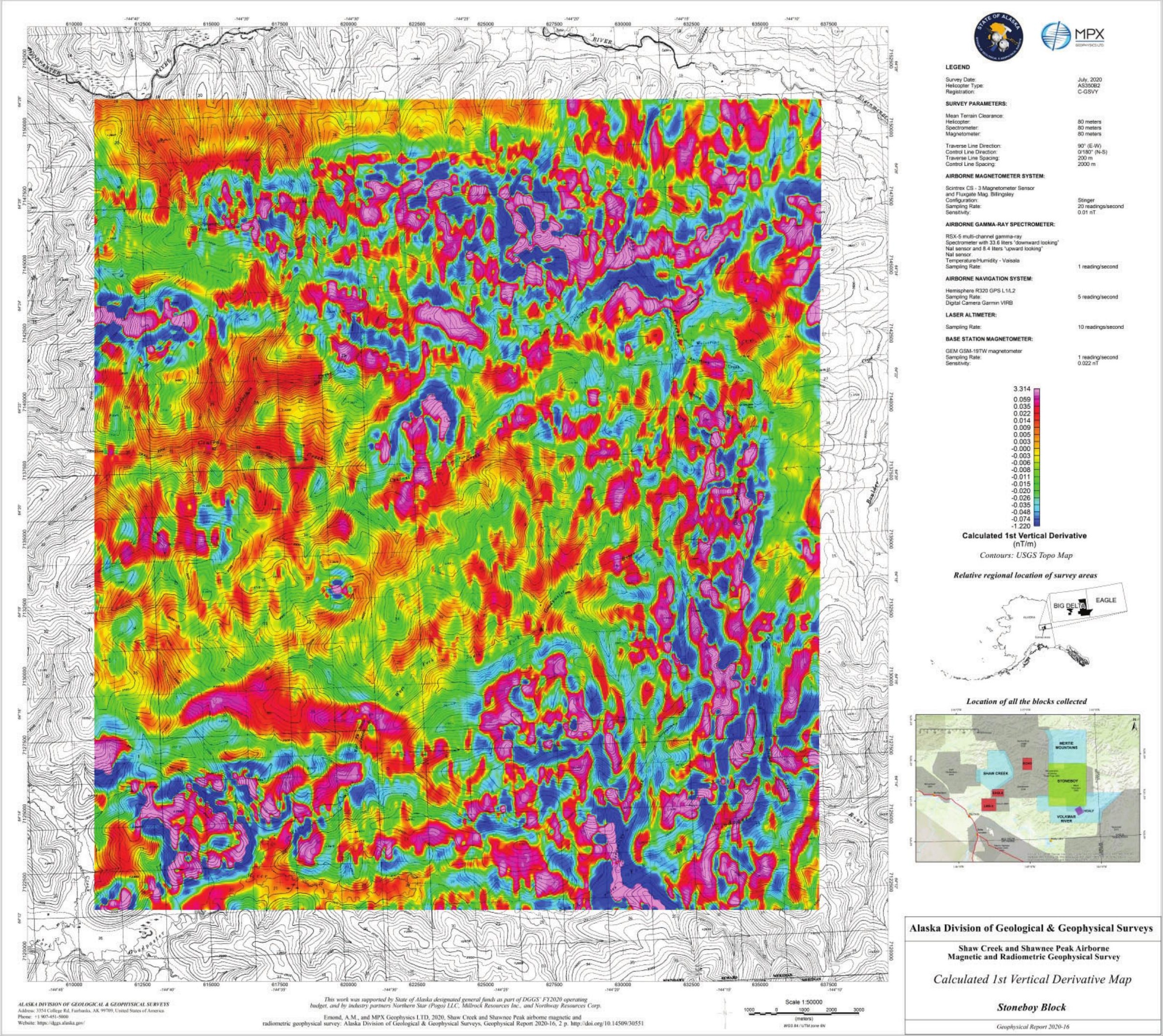




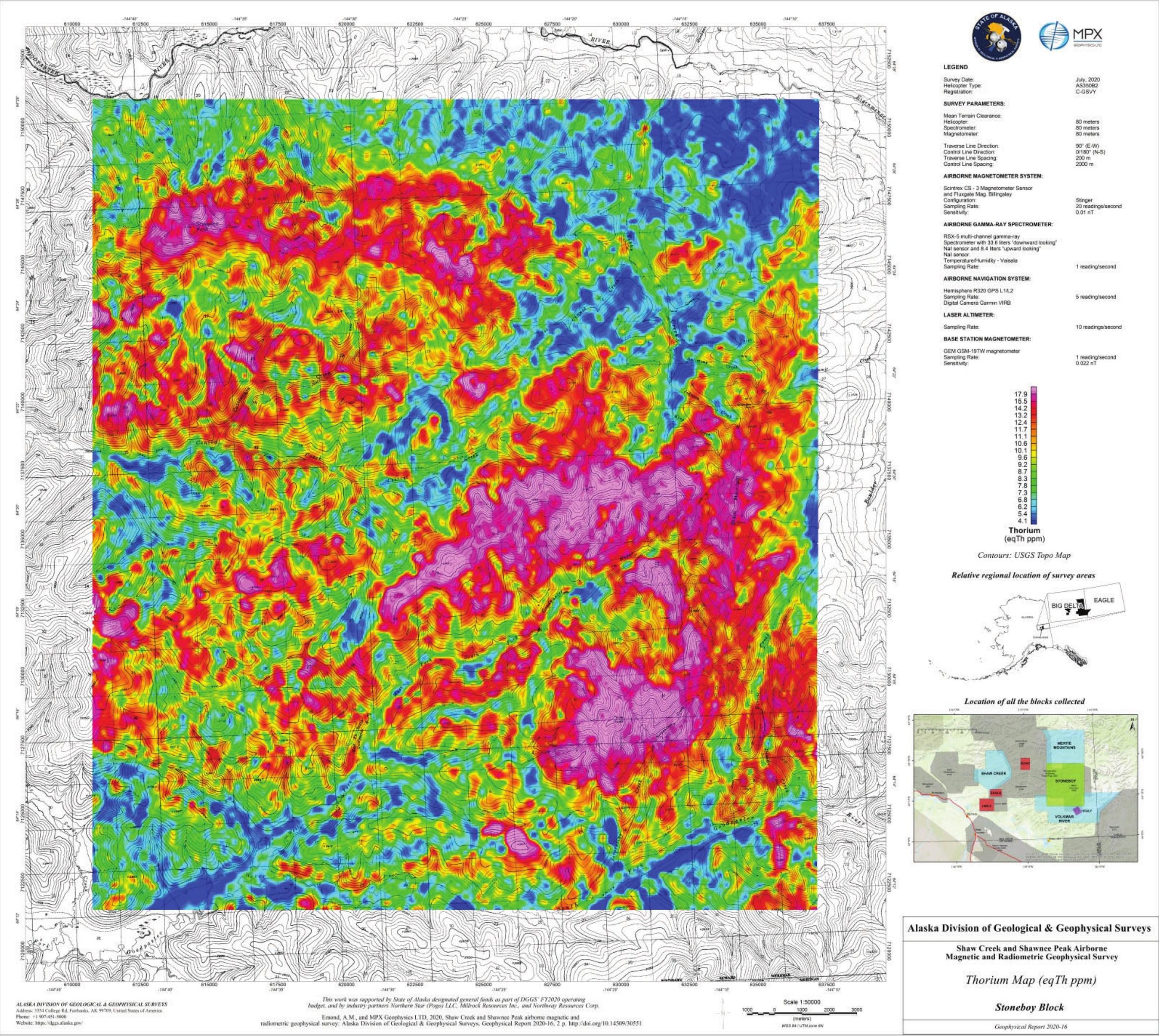




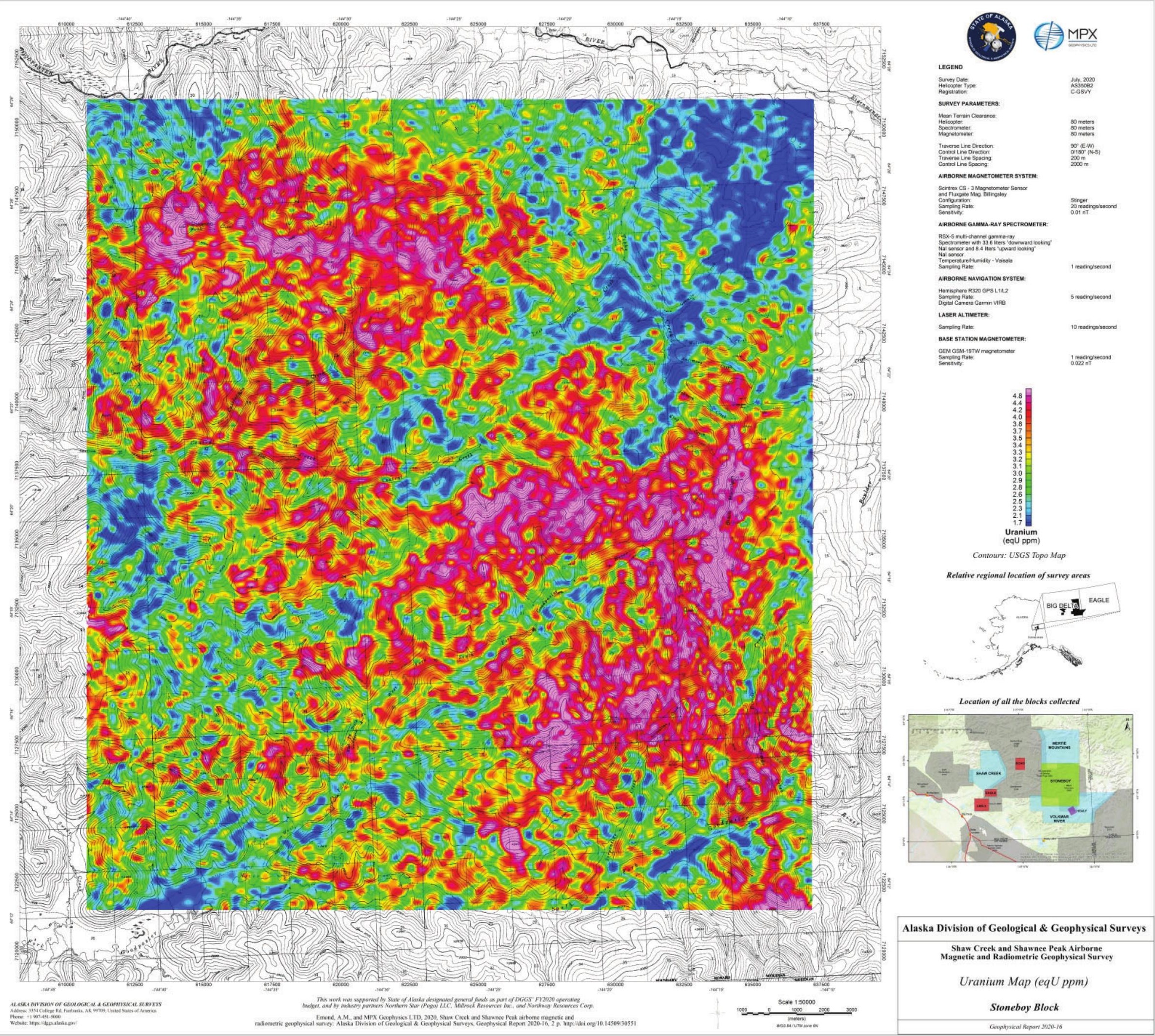




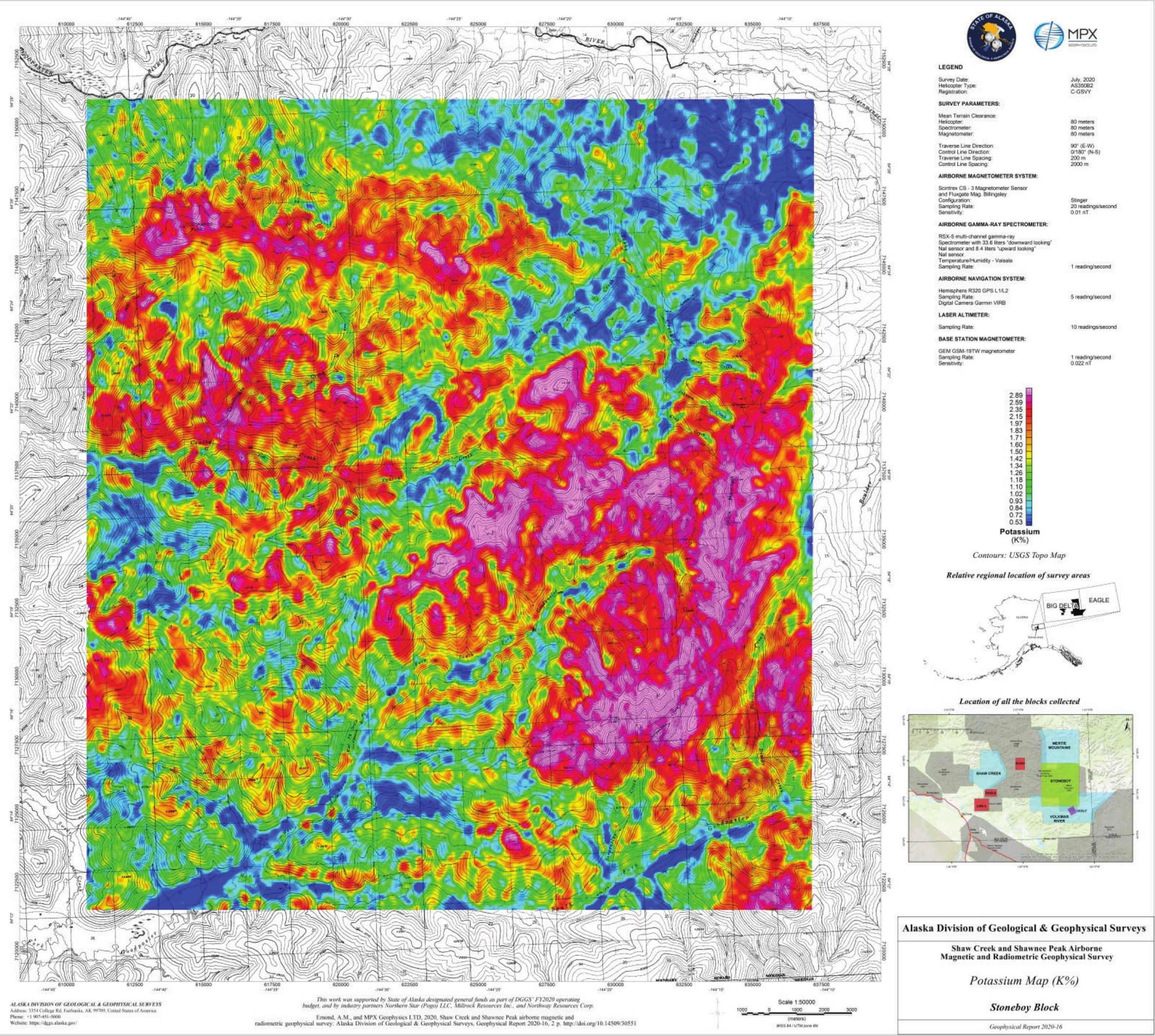




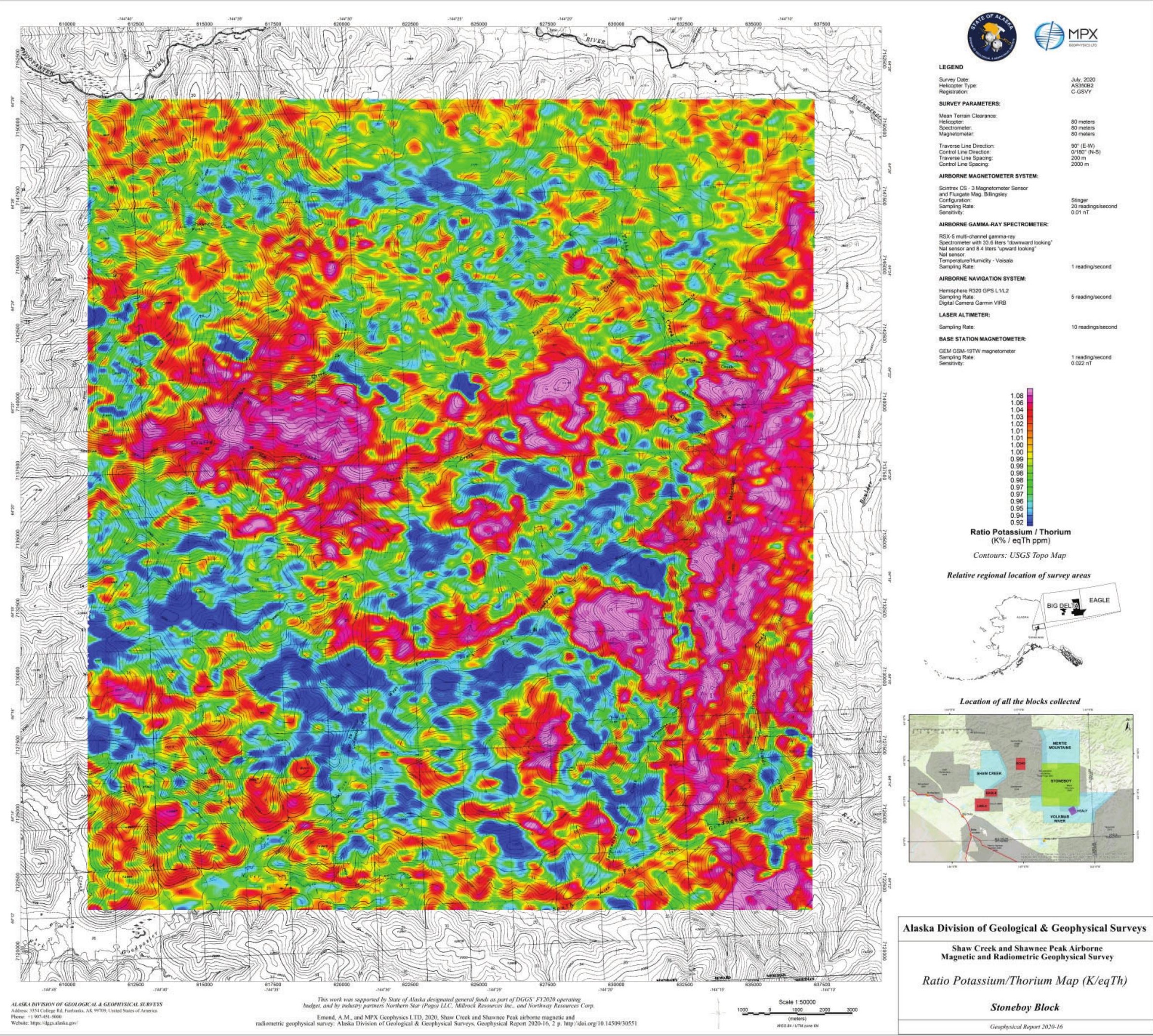




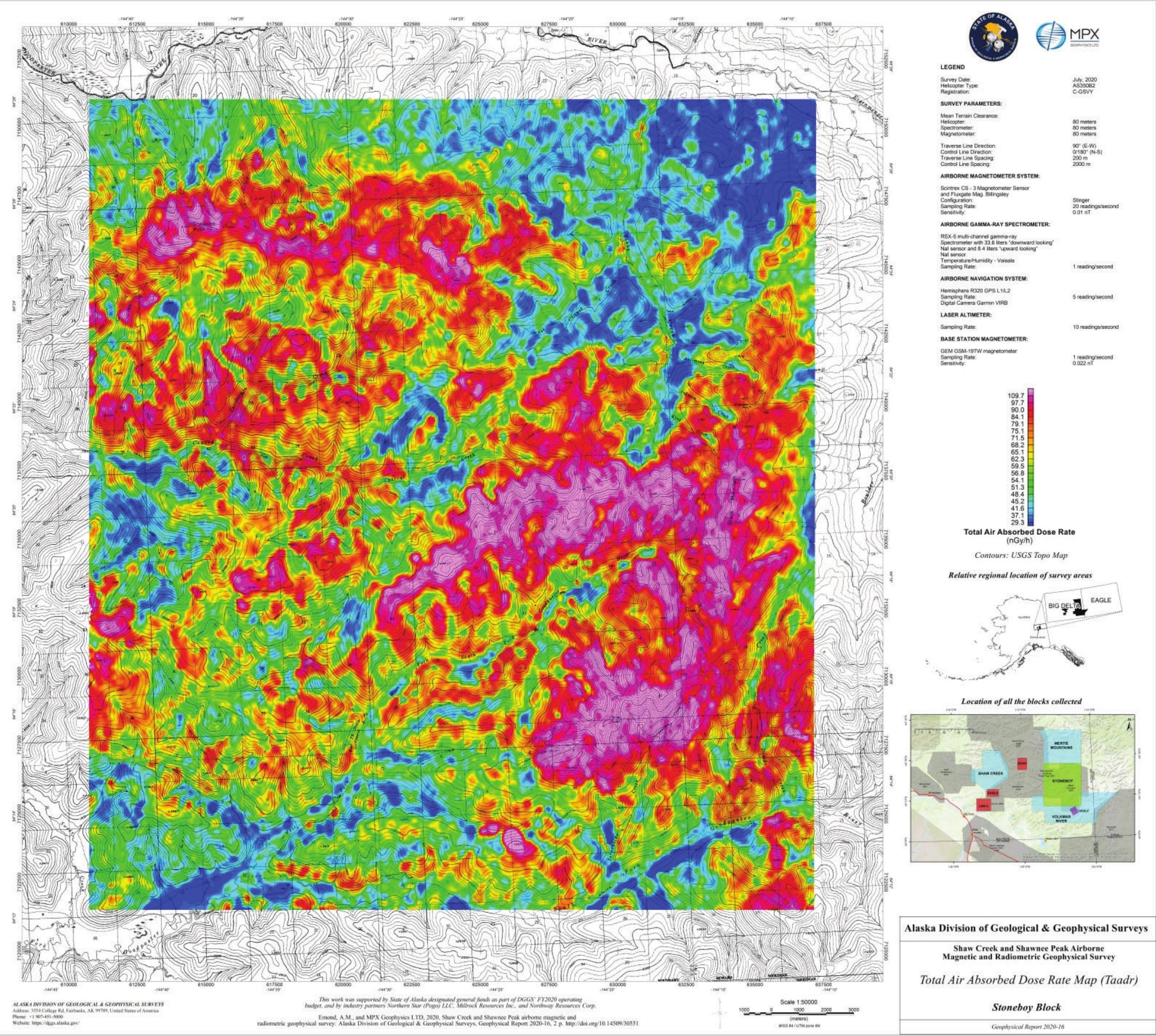




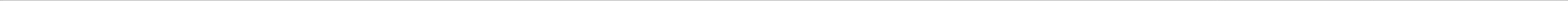




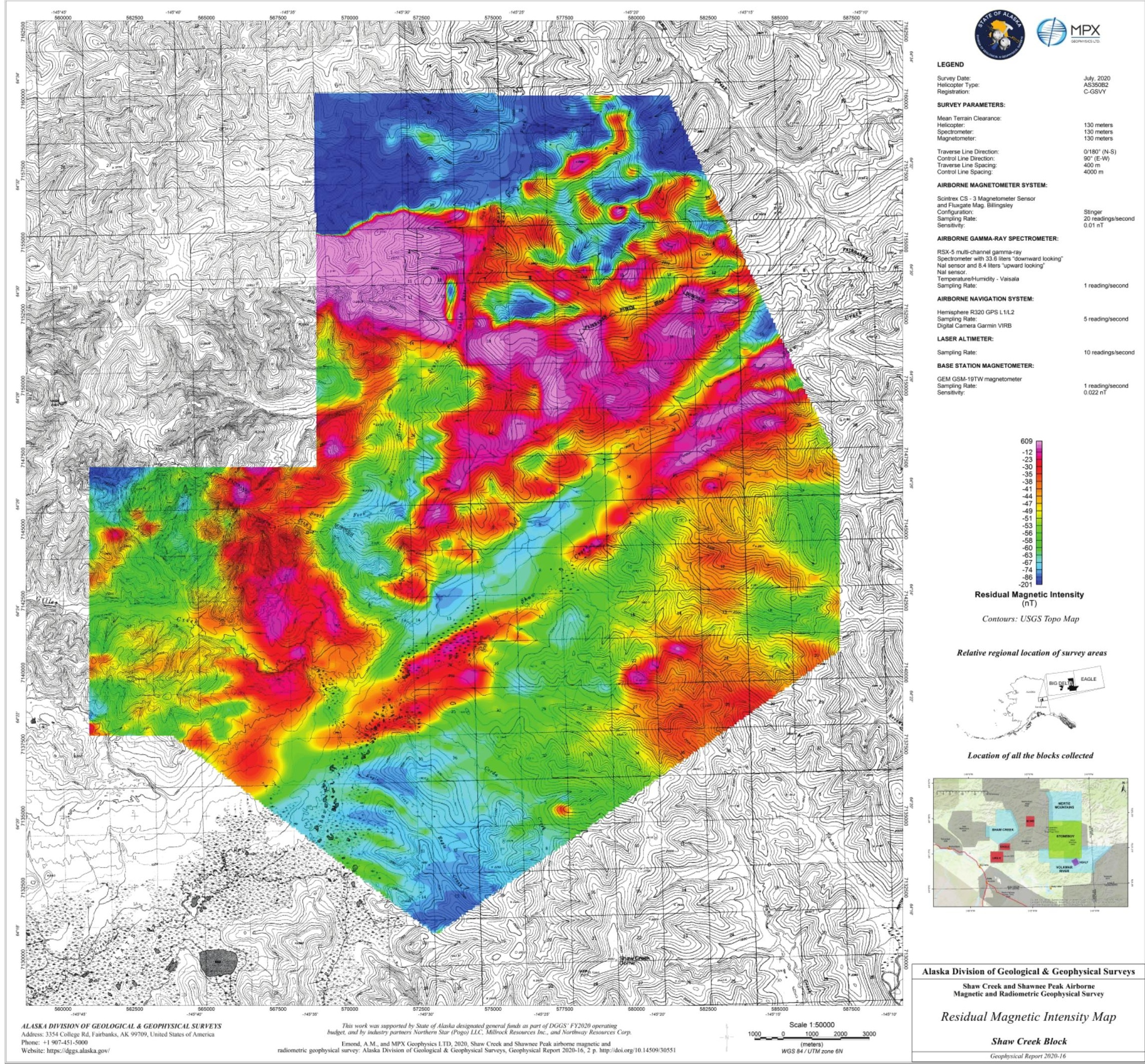




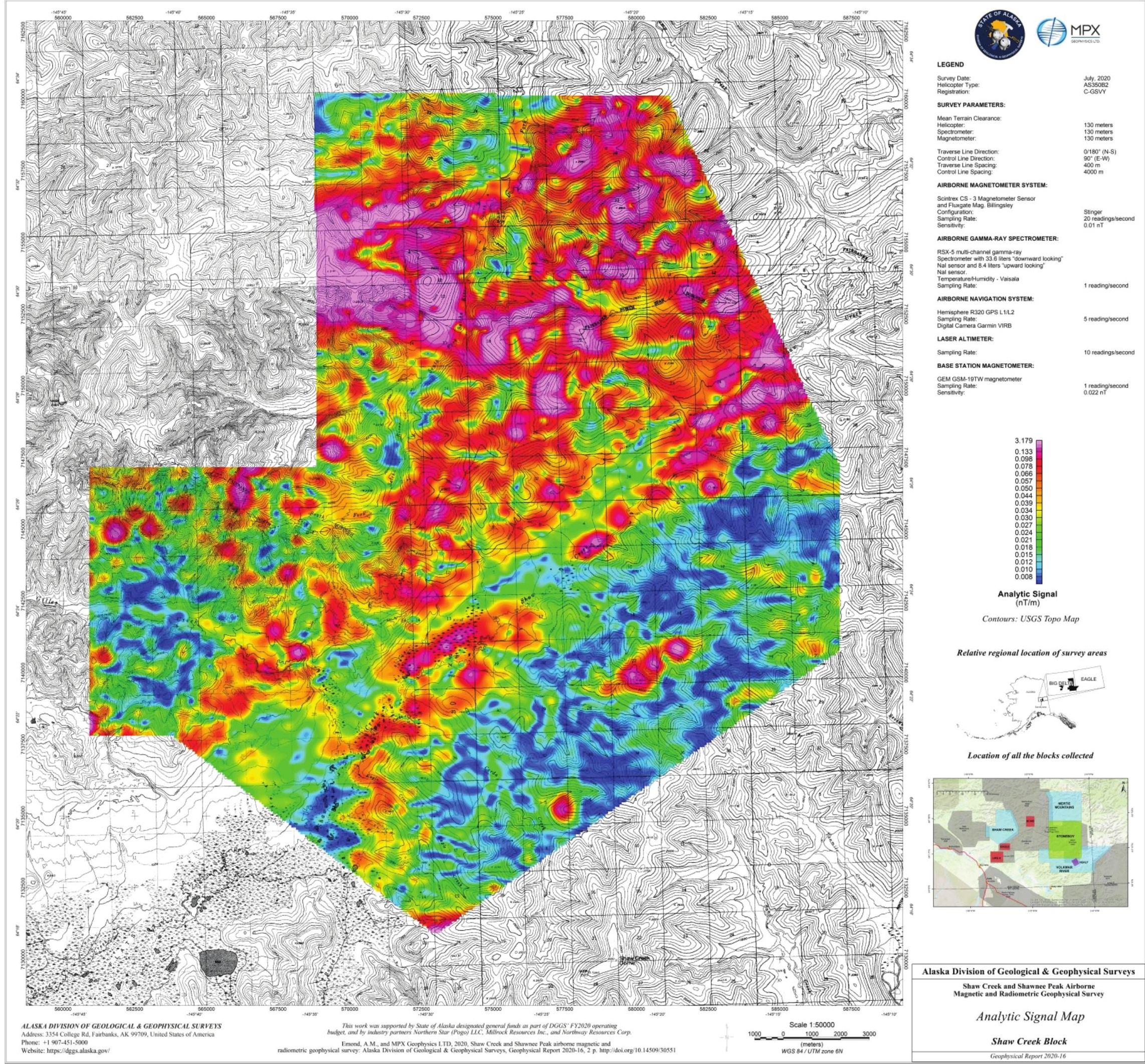




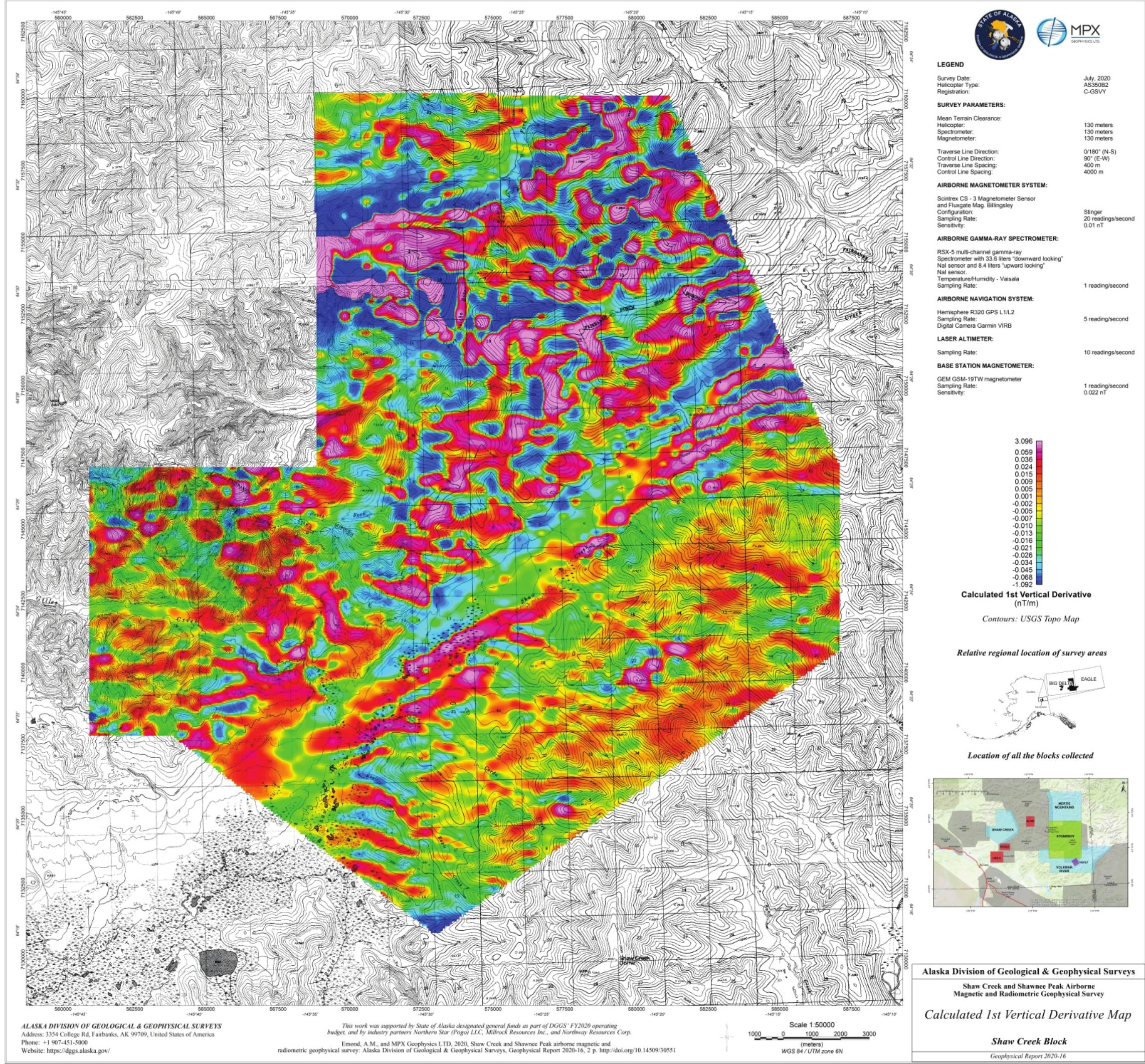




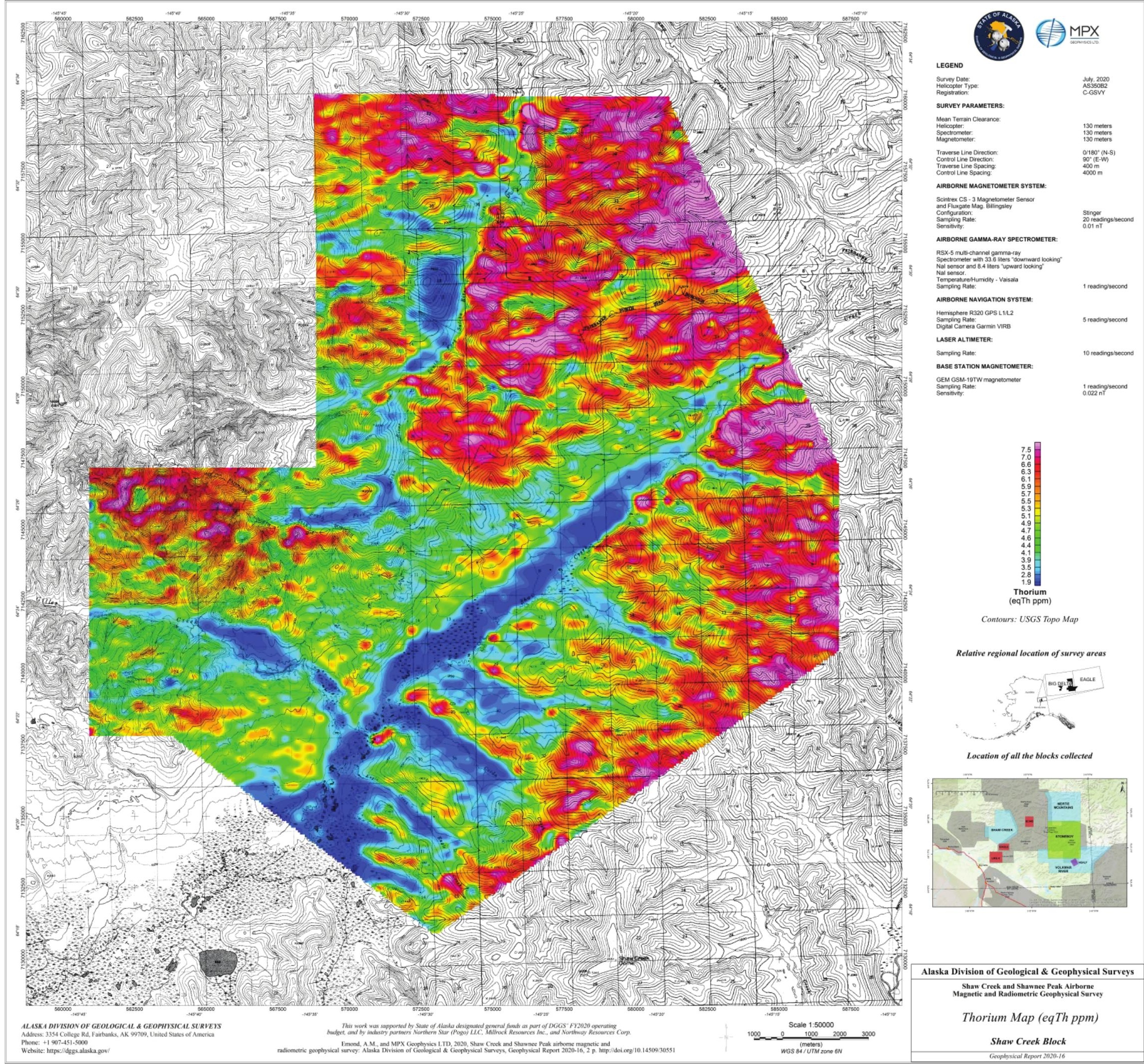




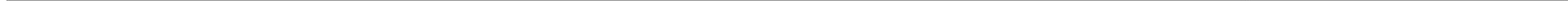




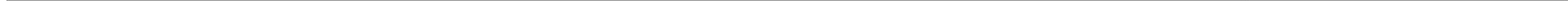




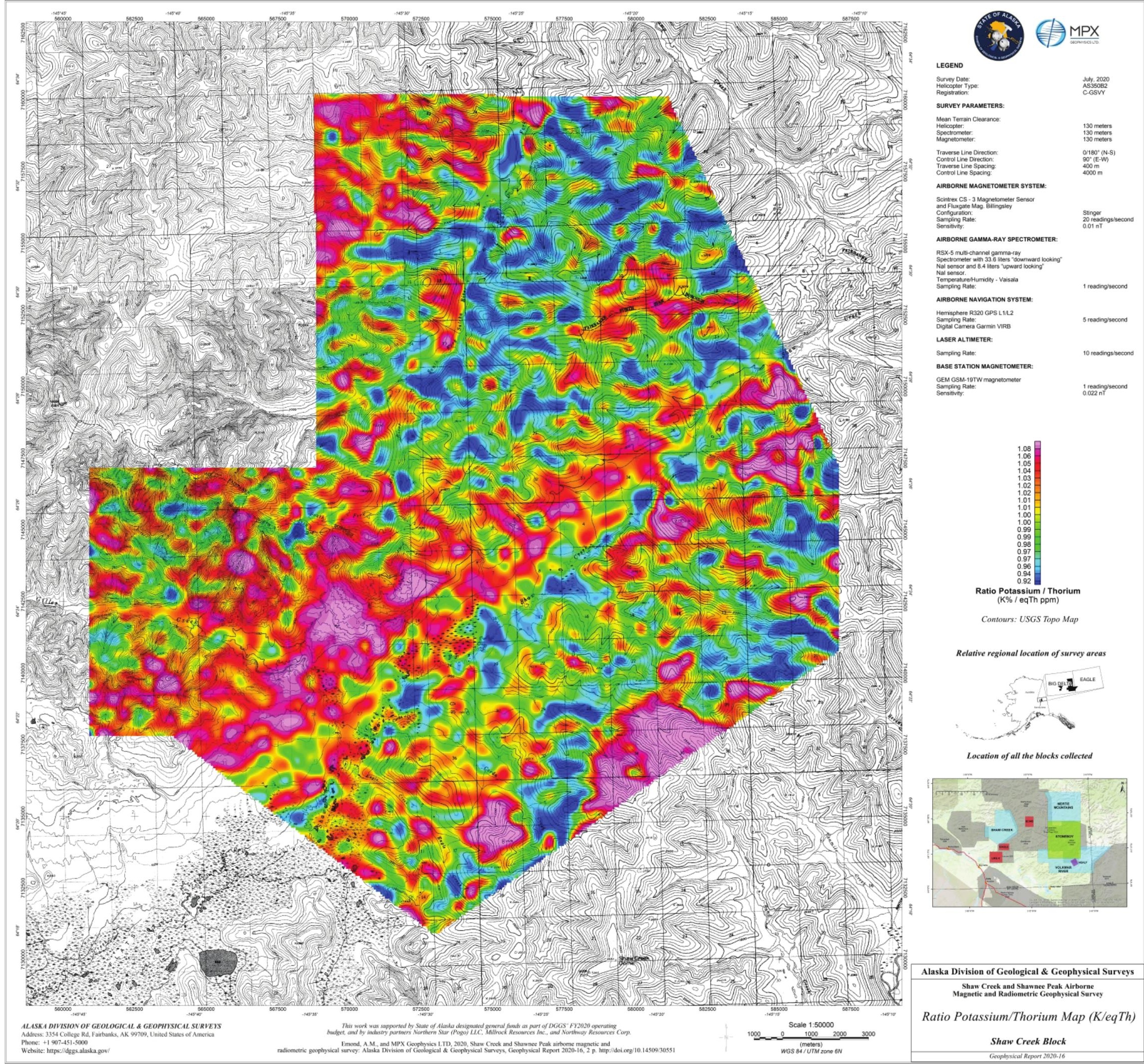




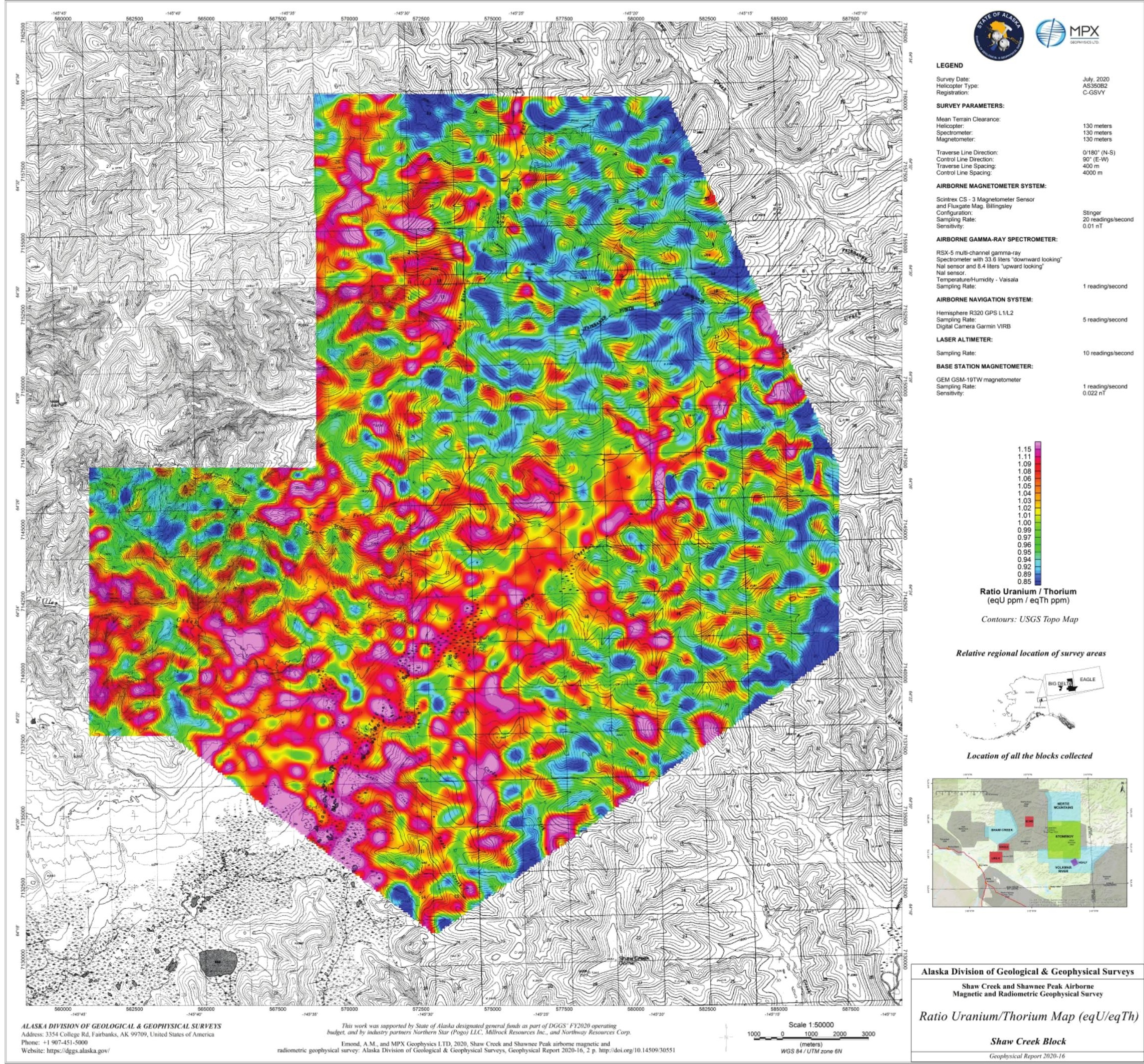




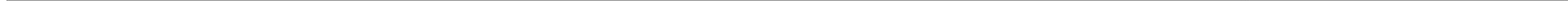




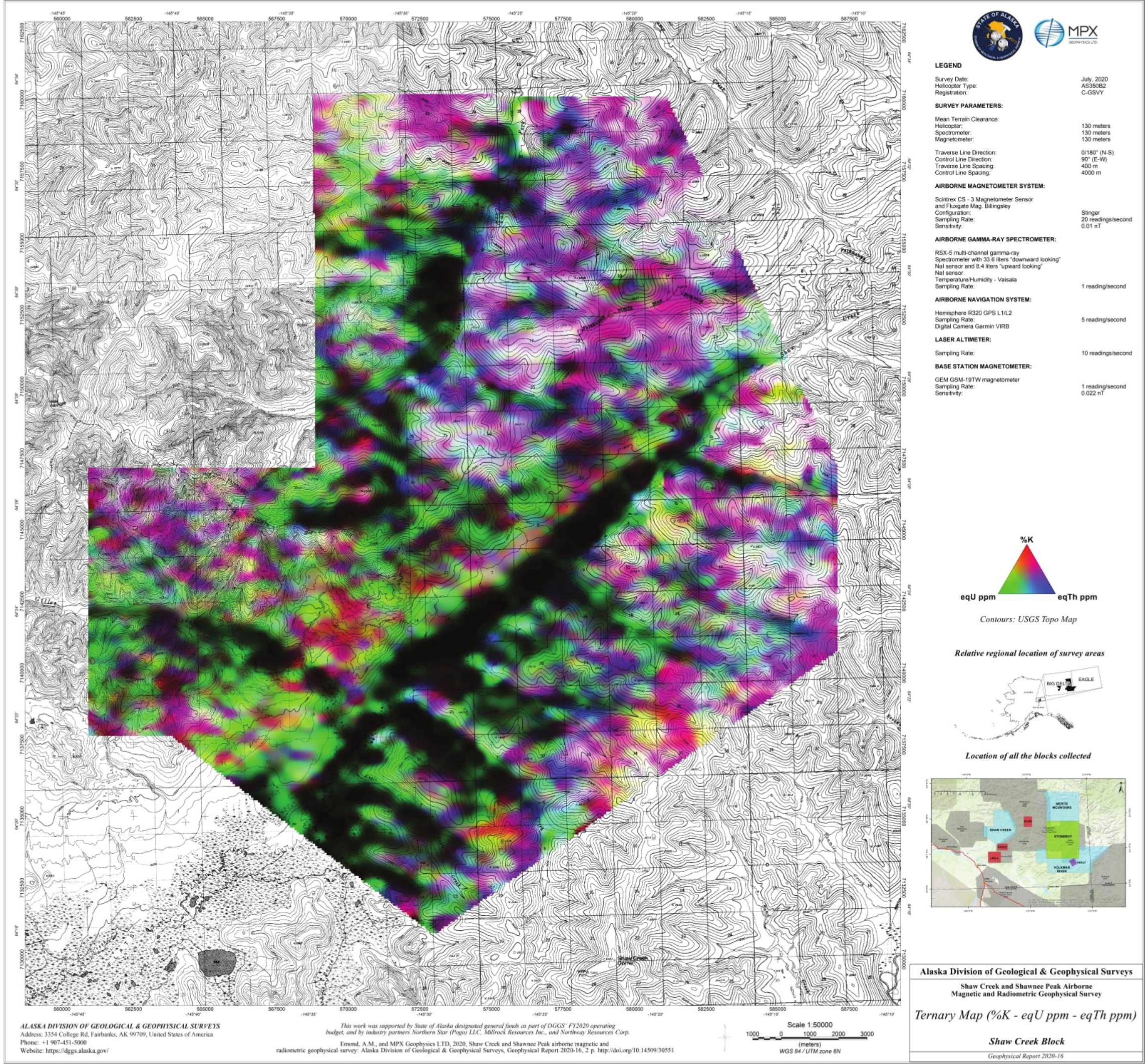




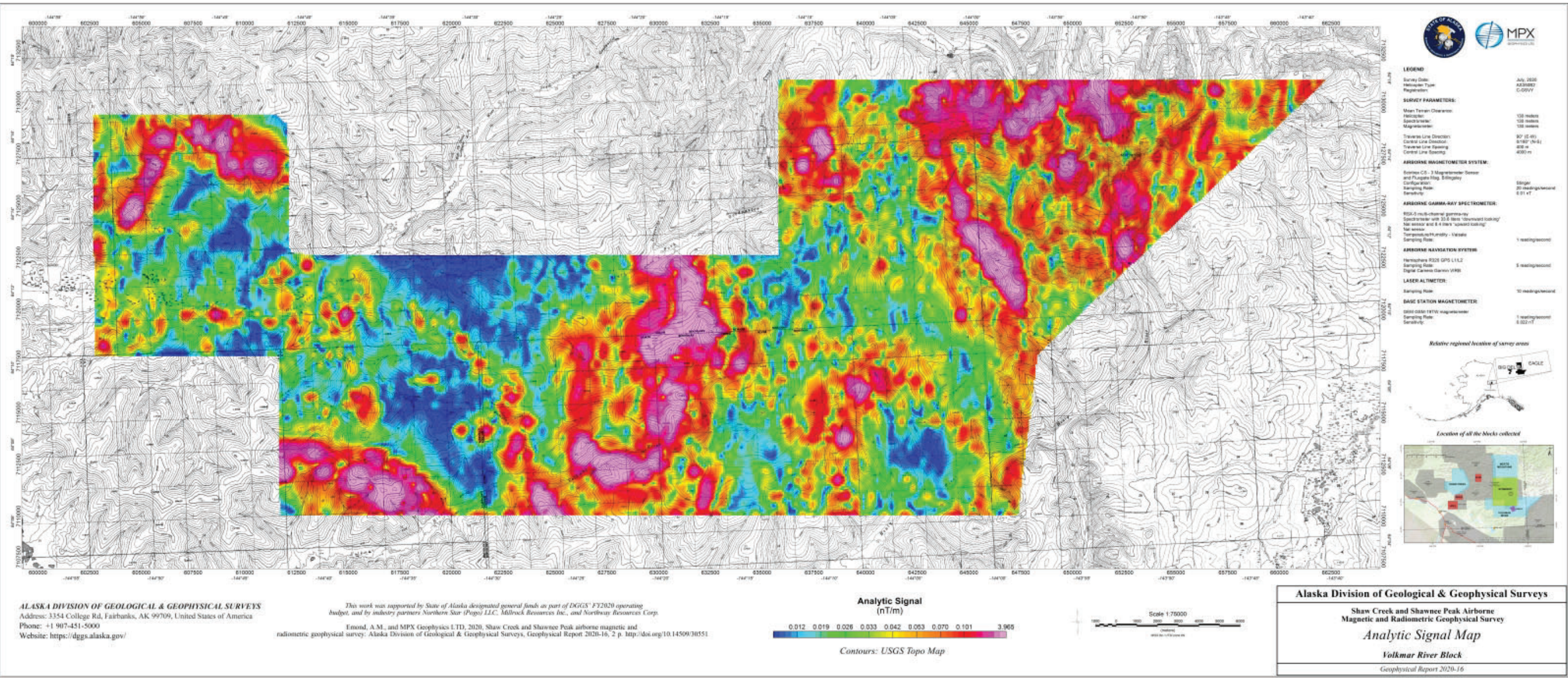




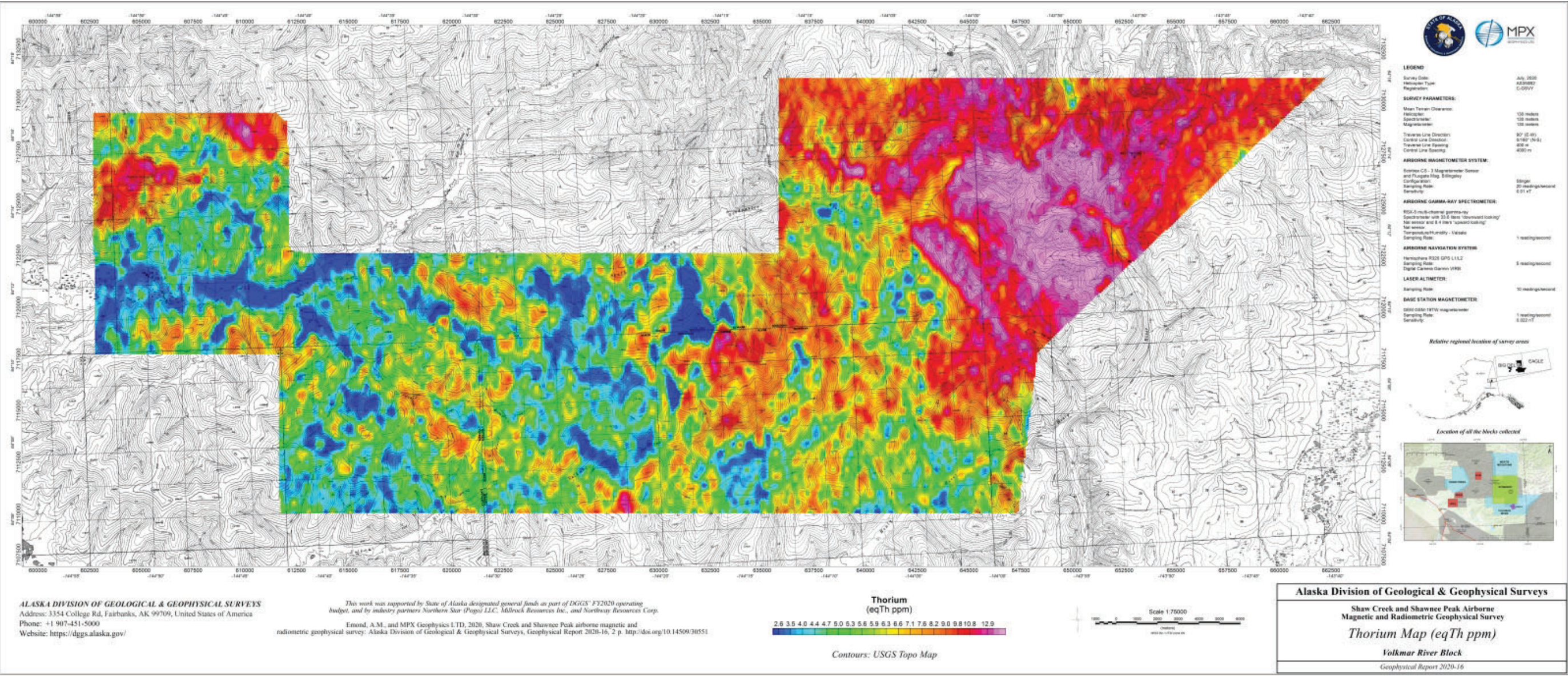




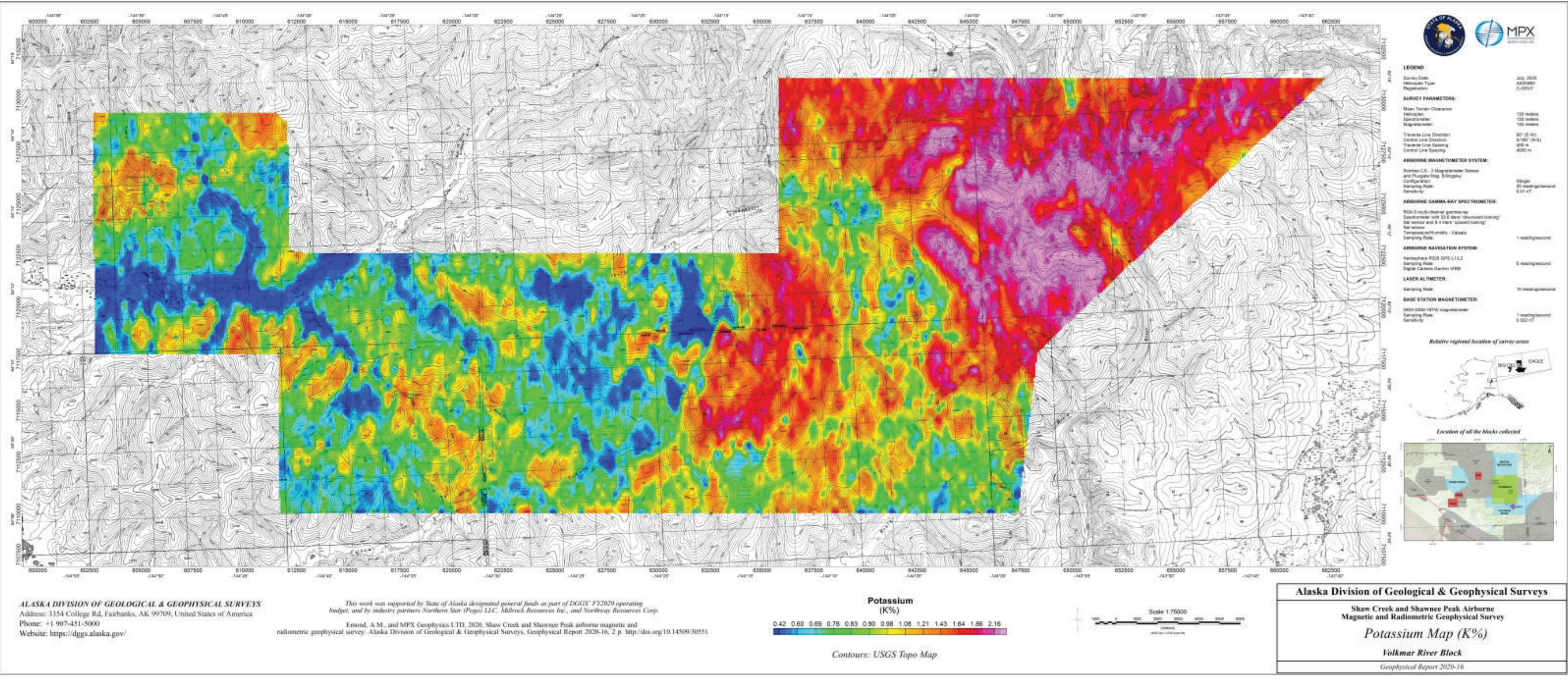




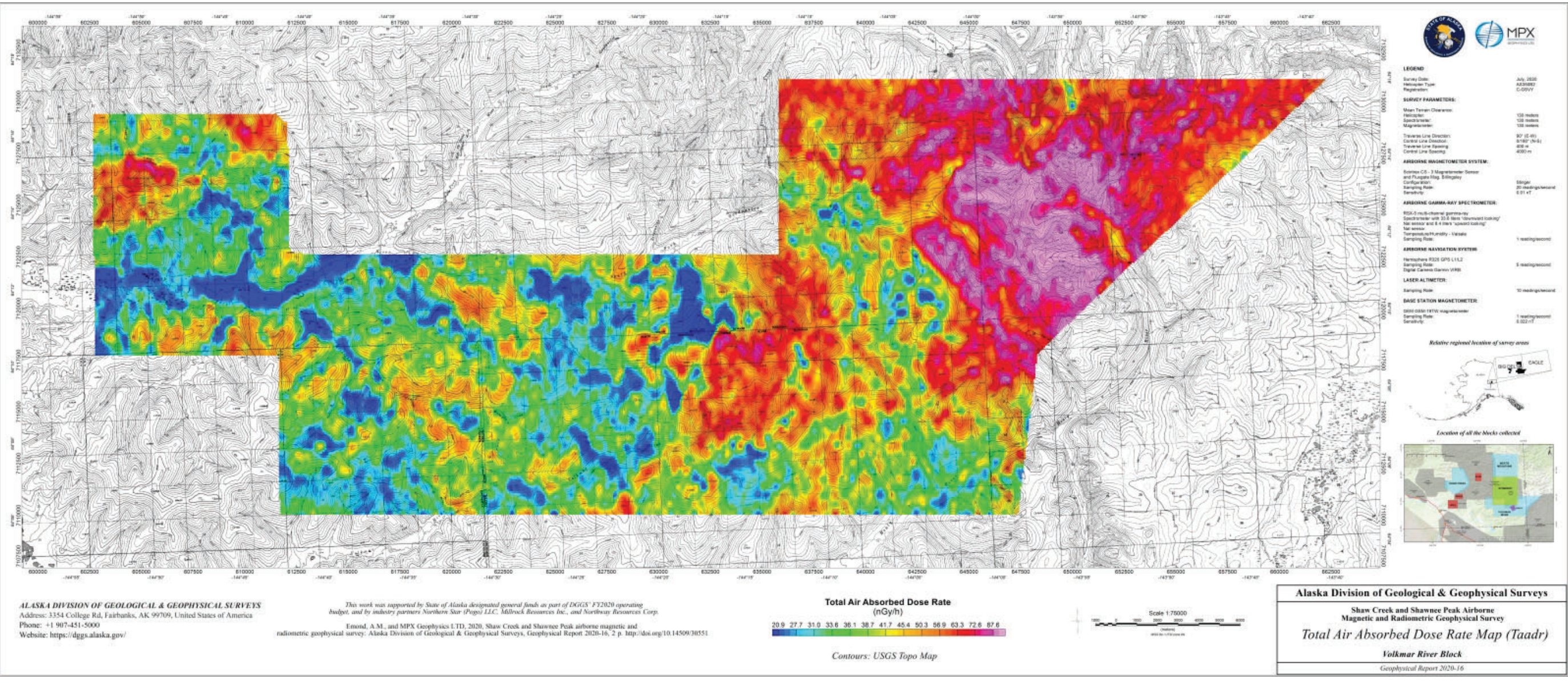


